\title{
The Political Economy of School Choice
}

\author{
James E. Ryan ${ }^{\dagger}$ and Michael Heise ${ }^{\dagger \dagger}$
}

\section{CONTENTS}

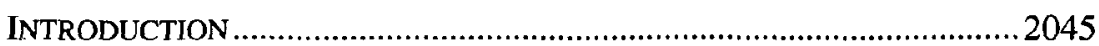

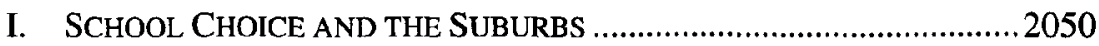

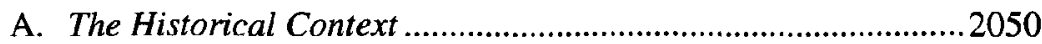

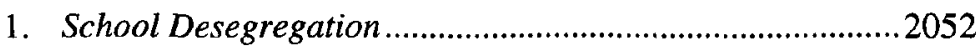

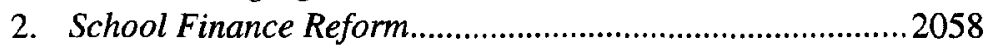

B. The Shape of School Choice .....................................................2063

1. Intradistrict Public School Choice ....................................2064

2. Interdistrict Public School Choice .......................................2066

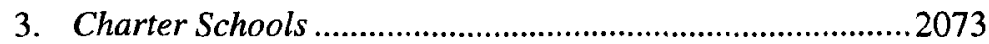

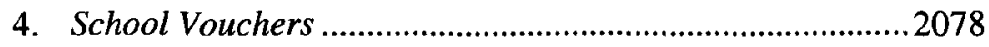

C. Pulling Together the Politics of Choice ...................................2085

1. The Radical Potential of School Choice ..............................2085

2. Suburban Political Power..................................................2088

II. The CONSEQUENCES OF CONSTRAINED CHOICES ...........................2091

A. Racial and Socioeconomic Integration .....................................2092

1. Residential Patterns and School District Demographics ....2093

2. Gauging the Impact of School Choice ................................2096

B. Academic Achievement...........................................................2102

1. Concentrated Poverty and Academic Achievement ..............2103

2. Evidence from Existing Choice Plans..................................2109

C. School Choice and School Competition ...................................2112

$\dagger$ Associate Professor, University of Virginia School of Law.

$\dagger+$ Professor, Case Western Reserve University School of Law.

For helpful comments, we thank Dawn Chutkow, Anne Coughlin, Kim Forde-Mazrui, Beth Garrett, John Harrison, John Jeffries, Mike Klarman, Daryl Levinson, Liz Magill, Alan Meese, Chris Sanchirico, Peter Schuck, Bill Stuntz, Stephen Sugarman, and the participants at faculty workshops at the University of Virginia and Case Western Reserve University law schools. Thanks as well to Angela Ciolfi, Daniel Fishbein, Michael Lockard, Beth Polzin, and the librarians at Virginia and Case Western Reserve for excellent research assistance. 


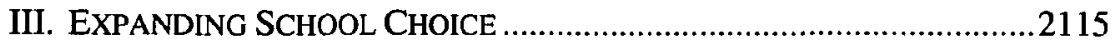

A. Working Within Existing Political Constraints ........................2118

1. Replicating and Strengthening Existing Programs .............2118

2. Creating Incentives for Expanding Choice .........................2124

B. Working To Alter the Politics of Choice ....................................22128

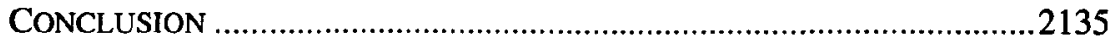

Imaged with the Permission of Yale Law Journal 


\section{INTRODUCTION}

Voices of moderation rarely shift the terms of any discussion, but this is our goal regarding the debate over school choice. This debate is filled with numerous claims by advocates and foes alike concerning the impact of choice on the future of public schools, the academic prospects of students, and racial and socioeconomic integration. Many of these claims are well known and equally well exaggerated. Proponents of private school choice, for example, suggest that choice is a "panacea" for the ills facing public schools, ${ }^{1}$ while opponents suggest that it could ruin public education. ${ }^{2}$ Just as the claims are becoming quite familiar, so too are (most of) the participants: On one side stand the teachers' unions and civil liberties groups who oppose at least private school choice, while on the other side stand free-market libertarians, religious conservatives, and an already significant and growing number of African-American parents. ${ }^{3}$

We believe that many claims regarding school choice miss the mark, and that they do so because those making them have failed to focus on the most important stakeholders in this debate: suburbanites, especially suburban parents. Suburbanites, by and large, are not wild about school choice, either public or private. Suburban parents are generally satisfied with the public schools their children attend, and they want to protect both the physical and the financial sanctity of these schools. ${ }^{4}$ School choice threatens both. It creates the generally unwelcome possibility that outsiders-particularly urban students-will be able to attend suburban schools at the expense of local taxpayers. Choice programs also raise the possibility that some locally raised revenues will exit local schools as students leave to attend either private schools or public schools outside of their residential districts. To the extent that choice may threaten the exclusivity and superiority of suburban schools, it may also threaten suburban housing values, which are linked to the quality of neighborhood

1. John E. Chubb \& Terry M. MOE, Politics, Markets and AMERICA's SChOOLS 217 (1990) (suggesting that "reformers would do well to entertain the notion that choice is a panacea").

2. See, e.g., James S. Liebman, Voice, Not Choice, 101 YALE L.J. 259, 277-93 (1991) (arguing that private school choice poses a serious threat to public education).

3. See PETER W. COOKSON, JR., SCHOOL CHOICE 17-37, 64-66 (1994) (describing proponents and opponents of school choice).

4. Terry M. MOE, Schools, Vouchers, and THE American Public 34-35 (2001) (describing suburban parents as "fairly satisfied" with their local public schools); Paul E. Peterson, School Choice: A Report Card, 6 VA. J. SOC. POL'Y \& L. 47, 56-57 (1998); David A. Bositis, School Vouchers Along the Color Line, N.Y. TIMES, Aug. 15, 2001, at A23; see also Lowell C. Rose \& Alec M. Gallup, The 32nd Annual Phi Delta Kappa/Gallup Poll of the Public's Attitudes Toward the Public Schools, PHI DELTA KAPPAN, Sept. 2000, at 41, 57 (noting that a higher percentage of suburbanites give their local schools a grade of " $A$ " or " $B$ " than do urban residents). 
schools. ${ }^{5}$ Like suburban parents, suburban homeowners without children thus have a strong, self-interested reason to be wary of school choice.

When suburbanites perceive a threat to their schools, they fight back, and they usually win. ${ }^{6}$ Consider school desegregation and school finance litigation. Efforts to integrate public schools came to a fairly abrupt halt in Milliken, precisely at the point when school desegregation threatened suburban schools. ${ }^{7}$ Urban school districts, especially outside the South, were left to experience the benefits and costs of school desegregation, while suburban schools remained largely outside of the fight. ${ }^{8}$ School finance litigation, meanwhile, never got off the ground in the United States Supreme Court, in part because it interfered with the same interest identified in Milliken-local control of schools. ${ }^{9}$ What local control meant in desegregation was essentially the ability of suburban schools to reserve their seats for neighborhood kids; what it meant in school finance litigation was the ability of suburban schools to spend unequal amounts of money on their own schools. School finance litigation has been somewhat successful on the state level, but, even after court-ordered reform, the general rule is that states must provide more money for poorer districts, while wealthier districts remain largely free to devote locally raised funds to local schools. ${ }^{10}$

We believe that the same dynamic will shape school choice. In fact, it already has. Most public school choice plans are intradistrict, meaning that students can choose schools within a particular district but cannot cross district lines. Even intradistrict "plans" typically do not allow unfettered choice and instead protect the ability of neighborhood kids to attend neighborhood schools. " Similarly, those states that have interdistrict plans almost always make participation voluntary or require schools to accept out-of-district students only when space is available. Most plans also fail to

5. See William A. Fischel, THE HOMEvoter Hypothesis 1-18 (2001) (arguing that school quality affects housing values, and that local taxpayers will tolerate property taxes provided that they are devoted to local schools); William T. Bogart \& Brian A. Cromwell, How Much Is a Neighborhood School Worth?, 47 J. URB. ECON. 280 (2000) (analyzing home price fluctuations generated by redrawing public school boundary lines in Shaker Heights, Ohio).

6. Their success is obviously related to their political power, which has grown substantially as a result of post-World War II population shifts away from the cities and into the suburbs. See, e.g., Marilyn J. Gittell, The Political Agenda of Education in the States, in STRATEGIES FOR SCHOOL EquTY 87 (Marilyn J. Gittell ed., 1998). For further discussion of this point, see infra Section I.A.

7. See Milliken v. Bradley, 418 U.S. 717 (1974).

8. For two excellent discussions of the impact of Milliken, see JOHN C. JEFFRIES, JR., JustiCE LEWIS F. POWELL, JR. 312-17 (1994); and J. HARVIE WILKINSON III, From BROWN TO BAKKE 216-49 (1979).

9. See San Antonio Indep. Sch. Dist. v. Rodriguez, 411 U.S. 1, 17 (1973) (holding that unequal funding of schools does not violate the Equal Protection Clause in part because reliance on property taxes for school finance promotes local control).

10. For a discussion of school finance litigation in state courts, see infra Subsection I.A.2.

11. The same phenomenon that we discuss regarding suburbanites, therefore, also seems to exist within some large, urban districts, where parents whose children are in good urban schools fight to protect the schools. 
provide funding for transportation, making traveling across district lines much more difficult in reality than it appears in theory. It is perhaps not surprising, then, that very few students attend public schools outside of their home school districts. ${ }^{12}$

Similar geographic constraints are also evident in the two most recent forms of school choice: charter schools and voucher programs. Charter school legislation often limits enrollment to children residing in the school district where the charter schools are located. Those states that allow students to cross district lines to attend a charter school almost uniformly give first priority to students living within the district in which the charter school is located. ${ }^{13}$ Similarly, the three publicly funded voucher programs that exist-in Milwaukee, Cleveland, and Florida - place significant limitations on where the vouchers may be used. In Milwaukee and Cleveland, vouchers may be used at private schools, provided the schools are located within city limits. The Cleveland program, in theory, also allows vouchers to be used at consenting suburban public schools, but no suburban schools have volunteered to accept voucher students. In Florida, finally, vouchers are given to students in persistently failing schools and may be used at any public or private school, provided that space is available. Transportation, however, is provided only if students choose a public school within their home districts. Moreover, the program is minuscule, as only two schools have "qualified" as persistently failing and thus only fifty-two students are currently receiving vouchers. ${ }^{14}$

Although we hope to resist the temptation to exaggerate, we feel confident in suggesting that understanding the political economy of school choice-and particularly the incentives and political power of suburbanites-is the key to understanding the current and future prospects of school choice, both public and private. Our central claim is that unless the politics surrounding school choice are altered, school choice plans will continue to be structured in ways that protect the physical and financial independence of suburban public schools. As a result, school choice plans will be geographically constrained and will generally tend to be intradistrict. Voucher programs, in particular, are likely to be limited to urban areas, where parents feel little attachment to neighborhood public schools and are desperate for relief.

If our central claim is correct and school choice plans continue to be limited in scope, it is possible to provide a more realistic assessment of the costs and benefits of school choice. Limited school choice plans will be neither a panacea for public school students nor much of a threat to the

12. For a discussion of intra- and interdistrict public school choice programs, see infra Subsections I.B.1-2.

13. For a discussion of charter school programs, see infra Subsection I.B.3.

14. For a discussion of vouchers, see infra Subsection I.B.4. 
status quo. Instead, as we hope to show, such plans will lead to, at best, limited academic improvement, little to no gain in racial and socioeconomic integration, and little productive competition among schools. This is not to deny that limited school choice plans have real costs or benefits, but rather to make the (hopefully) uncontroversial point that those costs and benefits will be as limited as the plans themselves. The larger and perhaps more controversial point is that significant gains in academic achievement, racial and socioeconomic integration, and productive competition are unlikely to materialize unless choice plans are structured to allow a meaningful opportunity for poorer students to attend schools outside of their neighborhoods and outside of their districts.

Although we harbor doubts that such plans can succeed politically, we do think that some steps can be taken to increase the options available to students within a choice program. In particular, we suggest that those interested in long-term change should focus on ways to alter the almost reflexive attachment to neighborhood public schools. We believe that one promising way to make progress on this goal is to support the increasingly popular drive for universal access to preschool. Preschools are not typically organized on a neighborhood basis and are just as often operated privately. Our supposition is that if more parents experience a range of governmentfunded choices among preschools, this experience could make them more supportive of programs that offer a similar range of choices among elementary and secondary schools.

The Article proceeds in three Parts. Part I begins by documenting a historical pattern in education reform, the central feature of which is that structural reforms tend to stop at the boundaries separating urban and suburban school districts, affecting the former and leaving the latter mostly untouched. We then show that school choice plans conform to this pattern and explain how the political economy of school choice, if unaltered, will produce limited school choice plans. Part II assesses the probable impact of limited school choice plans on racial and socioeconomic integration, academic achievement, and competition among public schools. We argue that limited choice plans will have a correspondingly limited impact on all three factors and suggest that the theoretical benefits of school choice will never be realized unless choice programs offer a meaningful opportunity for poorer students to escape impoverished schools. Part III offers suggestions as to how choice plans might be expanded in politically acceptable ways and how the politics of choice might be altered.

Before we proceed, two final introductory notes are in order. First, we recognize that we are painting with a broad brush; that variables such as race and socioeconomic status, politics, and economics interact in complicated ways; and that the political dynamics we describe may not hold true in every locale. In particular, we acknowledge that not all suburbs 
and suburbanites are alike. Racial and socioeconomic profiles differ among suburbs and thus among suburban schools. Inner-ring and outer-ring suburbs are often quite different from one another, with the former typically more racially diverse and generally poorer than the latter. ${ }^{15}$ As a result, in some suburbs, especially those where suburban parents are dissatisfied with local public schools, there may be less opposition to expansive choice programs than in others. Notwithstanding these variations among suburbs, it remains useful and important to distinguish generally between cities and suburbs, as well as between urban and suburban school systems. Significant differences in wealth, political power, and school quality typically separate inner cities and their surrounding suburbs. In addition, local school quality tends to be a more crucial component of housing values in suburbs than in cities, giving suburban residents a greater economic incentive to "protect" their local schools. ${ }^{16}$ Lastly, many suburbanites select the suburbs precisely because they wish to separate themselves from urban residents and urban problems, which presumably predisposes them to oppose efforts to link urban and suburban schools. ${ }^{17}$ As we explain, all of these factors, which generally differentiate suburbs and cities, will determine the contours and thus the efficacy of educational choice policies.

Second, some readers may wonder why we devote no attention to the constitutional question of whether vouchers may be used at private, religious schools. Legal commentators have devoted substantial attention to this issue, and the Supreme Court is, as of this writing, considering a case posing this very question. ${ }^{18}$ Some voucher proponents argue that legal uncertainty has seriously hampered the growth of voucher programs and

15. See, e.g., Mark Baldassare, Trouble in Paradise: The Suburban TRANSFORMATION IN AMERICA 169-75 (1986); Richard Briffault, Localism and Regionalism, 48 BUFF. L. REV. 1, 11 (2000); Jerry Frug, The Geography of Community, 48 STAN. L. REV. 1047, 1050 (1996).

16. See generally William T. Bogart, "Trading Places": The Role of Zoning in Promoting and Discouraging Intrametropolitan Trade, 51 CASE W. RES. L. REV. 697 (2001) (discussing zoning as a tool for protecting homeowners' investment in public goods such as education).

17. To be sure, the factors that prompt individuals to select suburbs as places to live are numerous and complex. See, e.g., William H. Frey, Central City White Flight: Racial and NonRacial Causes, 44 AM. SOC. REV. 425, 438-39 (1979) (discussing an array of factors that influence residential mobility); Harry L. Margulis, Household Mobility, Housing Traits, Public Goods, and School Quality in Cleveland's Metropolitan Statistical Area, 36 URB. AFF. REV. 646, 660, 670-73 (2001) (discussing factors contributing to home-buyer mobility). It is clear, however, that one factor motivating migration to the suburbs is a desire to separate oneself and one's family from urban problems, including problems in urban schools. See, e.g., Margulis, supra, at 660; Kirsten Hoffman, Note, Waterfront Development as an Urban Revitalization Tool: Boston's Waterfront Redevelopment Plan, 23 HARV. ENVTL. L. REV. 471, 471 (1997) (describing a desire for safer living and better schools as factors fueling flight to suburbs). For a classic account of the suburbanization of the United States, see generally KENNETH T. JACKSON, CRABGRASS FRONTIER: THE SUBURBANIZATION OF THE UNITED STATES (1985).

18. See Simmons-Harris v. Zelman, 234 F.3d 945 (6th Cir. 2000), cert. granted, 122 S. Ct. 23 (2001). For a historical account of the constitutional issues involved, see John C. Jeffries, Jr. \& James E. Ryan, A Political History of the Establishment Clause, 100 MICH. L. REV. 279 (2001). 
that a favorable Court decision will free the hand of cautious legislators, leading to an outburst of new voucher programs. ${ }^{19}$ It cannot be denied, of course, that a favorable decision might lead to additional voucher programs. The analysis in this Article, however, suggests that a Supreme Court decision approving the use of vouchers at religious schools is not likely to remove the serious political constraints on voucher programs, which will continue to keep those programs limited in size and scope. That is, we may see additional programs like the ones that exist in Cleveland and Milwaukee, but we are not at all likely to see anything close to a universal voucher program, no matter how enthusiastically the Court endorses the use of vouchers at religious schools. This does not mean that the Court's decision will be irrelevant. But it does suggest that a favorable Court decision will do less to remove the real constraints on voucher programs than it will to reveal them.

\section{SCHOOL CHOICE AND THE SUBURBS}

\section{A. The Historical Context}

To understand the current political dynamics of school choice, it is helpful to place school choice in historical context by considering the character and progression of earlier educational reforms. In the last fifty years, there have been two substantial efforts to alter the structure of public education in order to equalize educational opportunities: school desegregation and school finance reform. Both reforms initially sought to equalize opportunities by erasing the boundaries, whether physical or financial, that separated schools and school districts. School desegregation sought to erase physical boundaries between traditionally white and traditionally black schools, while school finance reform tried to eliminate financial boundaries between rich and poor schools by equalizing the resources available to all schools within a state. ${ }^{20}$ To a very real extent, both school desegregation and school finance reform pitted equality of opportunity against local control regarding student attendance and finances. Put differently, desegregation and school finance reform often threatened the concept of the traditional neighborhood school, attended only by local

19. See, e.g., Mark Walsh, Friedman Disappointed That Voucher Plans Aren't Bolder, EDUC. WK., Dec. 12, 2001, at 16; Jodi Wilgoren, School Vouchers: A Rose by Other Name?, N.Y. TiMES, Dec. 20, 2000, at A1.

20. For further discussion of the initial goals of school desegregation and school finance litigation, see James E. Ryan, Schools, Race, and Money, 109 YALE L.J. 249, 258-72 (1999). 
students and paid for primarily by local residents who could devote as much money to their "own" schools as they wished."

From one perspective, school choice-both public and private-is of a piece with school desegregation and school finance. To be sure, school choice is nascent by comparison and is capable of promoting goals, such as increased liberty and efficiency, that have little to do with equity. ${ }^{22}$ It is nonetheless fair to say that school choice represents the latest major attempt to restructure public education in order to equalize opportunities among students. The core principle of school choice is an equitable one, as school choice grants poorer students an opportunity-the chance to choose their own schools-that is now reserved for wealthier students. ${ }^{23}$ Moreover, school choice is theoretically linked to school desegregation and school finance reform, insofar as school choice will succeed in equalizing educational opportunities only to the extent that it succeeds in limiting local governmental control over student attendance and finances. The relationship is quite simple: To the extent that students have the right to choose their schools, local schools and districts will lose the right to choose their students and limit their revenues to local schools and residents.

The important question for school choice is whether it will share not only a theoretical link to school desegregation and school finance reform, but a practical one as well. In practice, school desegregation and school finance reform have fallen far short of the ideal of equalizing educational opportunity. Both school desegregation and school finance reform have foundered on the shoals of local control-or suburban local control, to be more precise. Indeed, if one were to conceive of these reforms as a contest between equality of opportunity and the suburban neighborhood school, one would have to declare the latter the overall winner. Consider first the

21. School desegregation did not always threaten the neighborhood school; in districts that were residentially integrated, school desegregation, if anything, was more consistent with the neighborhood school concept than was school segregation. See, e.g., Green v. County Sch. Bd., 391 U.S. 430 (1968) (striking down the district's "freedom-of-choice" plan for student assignments). Where neighborhoods were segregated, however, desegregation would obviously interfere with neighborhood schools.

22. John Chubb and Terry Moe, in their influential book Politics, Markets, and America's Schools, essentially make an efficiency-based argument in favor of school choice. See CHUBB \& MOE, supra note i; see also JEFFREY R. HENIG, RETHINKING SCHOOL CHOICE: LiMITS OF THE MARKET METAPHOR 57-58 (1994) (describing the theory that school choice will force schools "to increase the quality of education and the efficiency with which they deliver it, or else risk going out of business").

23. Some school choice advocates base their arguments on precisely this point. Two excellent examples are JOHN E. COONS \& STEPHEN D. SUGARMAN, SCHOLARSHIPS FOR CHILDREN (1992), and JOSEPH P. VITERITTI, CHOOSING EQUALITY (1999). Notably, it is political conservativesnot typically known for supporting efforts to ensure equality between the poor and the wealthywho often advocate school choice as a means of assuring that poor and middle-class parents have similar choices. RICHARD D. KAHLENBERG, ALL TOGETHER NOW: CREATING MidDLE-ClasS SCHOOLS THROUGH PUBLIC SCHOOL CHOICE 148 (2001). William Bennett, for example, argues that "poor parents ought to be able to make the same kinds of choices that middle-class parents can make for their children." $I d$. 
example of school desegregation, and in particular the reaction to courtordered busing.

\section{School Desegregation}

After allowing the South to resist desegregation for more than a decade, the Supreme. Court in 1968 finally ordered Southern school districts to make substantial efforts to integrate their schools. ${ }^{24}$ In 1971, in Swann v. Charlotte-Mecklenburg Board of Education, the Court went further and approved busing students within a district in order to integrate schools. ${ }^{25} \mathrm{By}$ the end of 1974, however, the Court had imposed a devastating limitation on urban school desegregation. In Milliken v. Bradley, the Court prohibited busing between urban and suburban school districts absent unusual and difficult-to-prove circumstances. ${ }^{26}$ All-out desegregation would continue within urban districts, which essentially meant that poor black kids and a dwindling number of white kids would be bused from one urban school to another. Most suburban schools, meanwhile, would remain inviolable, out of the reach of desegregation decrees and out of the tumultuous integration controversies that wracked cities like Boston. ${ }^{27}$

Milliken is often identified as the reason why school desegregation failed to reach suburban schools in Northern and Western metropolitan areas. Although an accurate assessment as far as it goes, it is important to recognize that Milliken was not decided in a political vacuum. On the contrary, Milliken came during a period of intense antibusing political activity, which began shortly after the Court's decision in Swann. Over the five years following Swann, the public consistently expressed strong opposition to mandatory busing in polls, and state and national politicians worked hard to limit it. ${ }^{28}$

24. The Court finally brought down the hammer in Green when it ordered school districts to take affirmative steps to integrate students, and to do so immediately. As the Court said, "The burden on a school board today is to come forward with a plan that promises realistically to work, and promises realistically to work now." Green, 391 U.S. at 439.

25. 402 U.S. 1 (1971).

26. 418 U.S. 717 (1974). Milliken held that interdistrict relief could only be ordered upon proof of an interdistrict violation, which the Court suggested might involve drawing district lines upon the basis of race. $I d$. at 745 . Such proof was hard to come by primarily because residential segregation between cities and suburbs made altering school district lines that tracked municipal boundaries largely unnecessary. See, e.g., GARY ORFIELD ET AL., DEEPENING SEGREGATION IN AMERICAN PUblic SCHOOLS 20 (1997).

27. See J. ANTHONY LUKAS, COMMON GROUND (1985) (describing the desegregation battle in Boston); see also WILKINSON, supra note 8, at 213-15, 222 (describing how busing primarily affected poor whites and blacks and noting that Milliken "saved' the suburbs").

28. For an excellent overview of the busing controversy, see generally THE SCHOOL BUSING CONTROVERSY: 1970-75 (Judith F. Buncher ed., 1975), which collects newspaper editorials and articles on busing decisions and antibusing legislation. 
On the national level, President Nixon blasted busing and defended neighborhood schools. Nixon campaigned on the issue in 1968 and repeated his criticism of busing once in office. ${ }^{29}$ In March of 1972, Nixon delivered a televised address devoted exclusively to the topic, in which he again denounced busing to achieve racial balance. ${ }^{30}$ Nixon made his appearance a few months after federal district court judges in Detroit and Richmond had ordered suburban districts to participate in metropolitan-wide desegregation plans. ${ }^{31}$ The Supreme Court would eventually overturn these orders, ${ }^{32}$ but in 1972 , it appeared to many that suburbanites might be forced to participate in wide-ranging busing plans. ${ }^{33}$

In his televised address, Nixon offered a compromise that would surface time and again in federal and state debates regarding education reform. He proposed legislation that would prohibit busing to achieve racial balance, suggesting that such legislation was consistent with the views of "[t]he great majority of Americans-white and black - [who] feel strongly that the busing of school children away from their own neighborhoods for the purpose of achieving racial balance is wrong." ${ }^{34}$ At the same time, the proposed legislation would direct additional federal funds to poor, innercity schools. Nixon exhorted his television audience:

It is time for us to make a national commitment to see that the schools in the central cities are upgraded so that the children who go there will have just as good a chance to get quality education as do the children who go to school in the suburbs. ${ }^{35}$

The compromise Nixon proposed to the nation was thus quite clear: Kids in inner-city schools would not be permitted to attend suburban schools, but they would be entitled to additional support and resources. ${ }^{36}$

Members of Congress, meanwhile, tripped over each other in a rush to introduce an array of measures designed to limit busing, ranging from constitutional amendments outlawing busing to legislation that would

29. GARY ORFIELD, MUST WE BUS? 242-44 (1978).

30. Transcript of Nixon's Statement on School Busing, N.Y. TIMES, Mar. 17, 1972, at 22.

31. See Bradley v. Milliken, 345 F. Supp. 914 (E.D. Mich. 1972); Bradley v. Sch. Bd., 338 F. Supp. 67 (E.D. Va. 1972).

32. Milliken v. Bradley, 418 U.S. 717 (1974); Richmond Sch. Bd. v. Bd. of Educ., 412 U.S. 92 (1973) (affirming, by a divided 4-4 vote, a Fourth Circuit decision that had overtumed the district court's merger order).

33. ORFIELD, supra note 29, at 247.

34. Transcript of Nixon's Statement on School Busing, supra note 30.

35. Id.

36. It is worth noting that Nixon's compromise proposal ignored the conclusions of his own Commission for School Finance that such compensatory programs were largely ineffectual. George R. METCALF, From litTle Rock to Boston: THE History of SCHOOL DESEGREGATION 144 (1983). 
restrict the ability of federal courts to hear desegregation cases. ${ }^{37}$ Congress even considered a proposal to deny gasoline for school buses that would take students farther than their neighborhood school. ${ }^{38}$ Congress eventually managed to enact legislation declaring that "the neighborhood is the appropriate basis for determining public school assignments" and purporting to prohibit courts or federal agencies from ordering the busing of any student beyond her neighborhood school. $^{39}$ Although important symbolically, the legislation had little effect, as courts interpreted it to allow busing as a remedy for de jure segregation. ${ }^{40}$ Congress also passed legislation that was more effective, though less publicized, which prohibited federally funded legal services organizations from working on desegregation litigation. ${ }^{41}$

Opposition to busing within Congress was not limited to the traditional group of Southern conservatives and Northern sympathizers who reflexively opposed strong efforts to desegregate schools. Instead, antibusing legislation in the early 1970s was just as likely to be introduced and supported by Northern moderates and liberals whose constituents were facing the prospect of busing for school desegregation. ${ }^{42}$ The measure to cut off gasoline for school buses, for example, was proposed by John Dingell, a Democrat from the Detroit suburbs. ${ }^{43}$ Similarly, Joseph Biden and Birch Bayh, Democrats from Delaware and Indiana, respectively, each introduced legislation in the mid-1970s to limit or prohibit cross-district busing for the purpose of school desegregation. They did so in response to political pressure from their suburban constituents. ${ }^{44}$

Dingell, Biden, and Bayh were not alone in seeking to immunize suburban schools from busing orders. ${ }^{45}$ Indeed, although members of

37. For descriptions of the various proposals introduced and considered in Congress, see ORFIELD, supra note 29, at 247-72; and GEOFFREY R. STONE ET AL., CONSTITUTIONAL LAW 46466 (4th ed. 2001).

38. ORFIELD, supra note 29 , at 255-57.

39. Equal Education Opportunities Act of 1974, Pub. L. No. 93-380, tit. II, \$\$ 202(a)(2), 215, 88 Stat. $514,514,517$ (codified at 20 U.S.C. $\$ \S 1701,1714$ (1994)).

40. See, e.g., United States v. Tex. Educ. Agency, 532 F.2d 380, 394 n. 18 (5th Cir. 1976), vacated on other grounds sub nom. Austin Indep. Sch. Dist. v. United States, 429 U.S. 990 (1976).

41. The Legal Services Corporation Act, enacted on July 25, 1974, prohibited funds available under the Act from being used "to provide legal assistance with respect to any proceeding or litigation relating to the desegregation of any elementary or secondary school or school system." Legal Services Corporation Act of 1974, Pub. L. No. 93-355, sec. 2, \& 1007(b)(7), 88 Stat. 378, 385 (codified at 42 U.S.C. $\$ 2996 \mathrm{f}(\mathrm{b})(9)$ (1994)).

42. George Metcalf describes a virtual stampede of liberals rushing to vote in favor of antibusing measures following an outpouring of antibusing sentiment from their constituents. METCALF, supra note 36 , at 117, 162-63.

43. Id. at 163, 193; ORFIELD, supra note 29 , at 255 .

44. On Bayh's proposal and political motivation, see ORFIELD, supra note 29 , at 263 . On the Biden episode, see METCALF, supra note 36, at 235-37; and ORFIELD, supra note 29, at 272-73.

45. LILLIAN B. RUBIN, BUSING \& BACKLASH 6 (1972) (describing how "[m]any northern liberal Democrats, who until [the early 1970s] had been articulate spokesmen for school 
Congress disagreed on the various proposals introduced to restrict busing, on the question of restricting busing across city-suburban lines, there was a large consensus ${ }^{46}$ A similar consensus existed outside of Congress. Polls in the early 1970s consistently revealed strong opposition to busing, with one Gallup Poll in 1973 indicating that ninety-five percent of those surveyed opposed busing to achieve integration. ${ }^{47}$ Middle-class communities that faced the prospect of busing "protested on an unprecedented scale," and the mass movement taking to the streets in the early 1970s "marched not under the banner of 'INTEGRATION NOW' but with signs reading 'PRESERVE OUR NEIGHBORHOOD SCHOOLS." ${ }^{48}$ Not only did white communities oppose busing, but there was little organized support among blacks for busing. ${ }^{49}$ Many blacks, like many whites, preferred sending their children to neighborhood schools to placing them on buses to attend distant schools..$^{50}$ It is not surprising, then, that members of Congress could agree in principle that a better strategy than integrating suburban and urban students would be to enhance education within urban schools by devoting greater resources to those schools. This, of course, was precisely the compromise proposed by Nixon in his 1972 televised address.

Perhaps not coincidentally, this was also the compromise ultimately adopted by the Supreme Court. Three years after the Court prohibited busing between Detroit city schools and the surrounding suburbs, the Court approved remedial funding for Detroit city schools. In Milliken II, the Court held that states could be required to fund remedial and compensatory education programs in formerly segregated schools. ${ }^{51}$ What was true for Detroit became true for a host of other metropolitan areas in the North and West: Students in urban school districts would be confined to those districts but would receive additional resources under the guise of "desegregation" remedies. ${ }^{52}$

integration, cast their votes for thesc antibusing” measures); Alexander M. Bickel, Undertaking the Busing Snarl, NEW REPUBLIC, Sept. 23-30, 1972, reprinted in THE GREAT SCHOOL BuS CONTROVERSY 27, 28-29 (Micolaus Mills ed., 1973) (describing how Northem liberals took the lead in passing measures that virtually mandated neighborhood schools).

46. See ORFIELD, supra note 29 , at 233-78.

47. See THE SCHOOL BUSING CONTROVERSY: 1970-75, supra note 28, at 207, 210, 228, 231.

48. ORFIELD, supra note 29 , at 6, 248. For an interesting account of the fight over busing in the Richmond Unified District-a large, urban district in Northern California - see RUBIN, supra note 45 .

49. ORFIELD, supra note 29, at 248; WILKINSON, supra note 8, at 232-34; Christine H. Rossell, The Convergence of Black and White Attitudes on School Desegregation Issues During the Four Decade Evolution of the Plans, 36 WM. \& MARY L. REV. 613, 639-45 (1995).

50. See WILKINSON, supra note 8 , at 233 ; see also METCALF, supra note 36 , at 192 (noting that Detroit's black mayor, Coleman Young, declared after the Milliken decision that he would shed "no big tears for cross-district busing" and instead demanded equal funding for Detroit schools).

51. Milliken v. Bradley, 433 U.S. 267 (1977).

52. See Ryan, supra note 20 , at 263-64. 
It would be easy, and it may well be accurate, to suggest that the Supreme Court was influenced by the dominant and widespread political opposition to busing, especially busing between urban and suburban schools. ${ }^{53}$ Whether political pressure motivated the majority in Milliken I and Milliken II, however, is less important for the purposes of this Article than the fact that political pressure existed. Rather than contradict popular opinion or political actions, both decisions reinforced and ultimately superseded widespread political activities designed to accomplish the same goal. The Court, like state and federal politicians, acted to protect "local control" of the schools, which in the context of Milliken and interdistrict integration meant the physical independence of the suburban neighborhood school. ${ }^{54}$ The Court's efforts largely succeeded. After Milliken I, lower courts ordered interdistrict busing in only four metropolitan areas: Indianapolis, Little Rock, Wilmington, and Louisville. ${ }^{55}$ In addition to these court orders, lower federal courts approved a settlement in a St. Louis desegregation case that involved voluntary interdistrict busing ${ }^{56}$ and a small number of metropolitan areas in the South were integrated because the formerly segregated school districts happened to encompass both city and suburb. ${ }^{57}$ On the whole, however, suburban school districts received a pass and were exempted from busing plans. ${ }^{58}$

It is tempting to imagine that opposition to cross-district busing is a thing of the past and that suburbanites would now welcome the opportunity to open their schools to students from poor, urban neighborhoods.

53. Justice Marshall, in dissent, stated as much: “Today's holding, I fear, is more a reflection of a perceived public mood that we have gone far enough in enforcing the Constitution's guarantee of equal justice than it is the product of neutral principles of law." Milliken v. Bradley, 418 U.S. 717, 814 (1974) (Marshall, J., dissenting). For a similar but more strident argument, see Nathaniel R. Jones, An Anti-Black Strategy and the Supreme Court, 4 J.L. \& EDUC. 203 (1975). Jones, general counsel of the NAACP at the time (and later a federal court of appeals judge), argued that Milliken represented "the sad but inevitable culmination of a national anti-black strategy" and that it should be "viewed in light of the political climate created by the [Nixon] administration." Id. at 203; see also WILKINSON, supra note 8, at 222 (suggesting that precedent supported a metropolitan-wide remedy in Milliken).

54. See Milliken, 418 U.S. at 741-42 (suggesting that school district lines should be protected when possible because "[n]o single tradition in public education is more deeply rooted than local control over the operation of schools").

55. See Little Rock Sch. Dist. v. Pulaski County Special Sch. Dist. No. 1, 778 F.2d 404 (8th Cir. 1985); United States v. Bd. of Sch. Comm'rs, 637 F.2d 1101 (7th Cir. 1980); Evans v. Buchanan, 582 F.2d 750 (3d Cir. 1978); Newburg Area Council, Inc. v. Bd. of Educ., 510 F.2d 1358 (6th Cir. 1974).

56. See Liddell v. Missouri, 731 F.2d 1294 (8th Cir. 1984). For further discussion of this plan, which is currently being dismantled, see infra Subsection I.B.2.

57. Charlotte-Mecklenburg is the most well-known. Others included several large districts in Florida, as well as the Las Vegas metropolitan area and the Nashville-Davidson County district in Tennessee. See ORFIELD, supra note 29, at 412 tbl.12-1 (listing metropolitan-wide desegregation plans); Gary Orfield, Metropolitan School Desegregation: Impacts on Metropolitan Society, 80 MinN. L. REV. 825, 832-33 tbl.1 (1996).

58. Cf. WILKINSON, supra note 8, at 215 ("With busing [the Court] declared an all-out war, but then decided that much of the citizenry was not obliged to participate."). 
Tempting, but largely untrue. Although there are signs of progress regarding attitudes toward racial and socioeconomic integration of schools, as well as some regional variations, there is little sign that opposition to mandatory interdistrict integration has abated. In fact, the busing controversy that enveloped the country in the early 1970 s is currently being replayed in Connecticut, and the sequel is turning out to be a miniaturized version of the original.

In 1996, the Connecticut Supreme Court ruled in Sheff v. O'Neill that de facto segregation violated the state constitution, a holding that essentially outlawed current school district lines and required the state to take affirmative steps to ensure that all schools were racially balanced. ${ }^{59}$ The Court allowed the legislature to devise a remedial plan. Cross-district busing would obviously remedy the identified violation, but state political leaders took this option off the table almost immediately. ${ }^{60}$ Hearkening back to Nixon's compromise in 1972, the Governor and state legislators instead proposed to spend more money on racially isolated urban schools and slowly offer more opportunities for interdistrict school choice. ${ }^{61}$ Given the attitude of the Governor and the legislature, it is not surprising that very few students in Connecticut have crossed district lines to attend school since the 1996 decision. $^{62}$ Meanwhile, racial isolation in the Hartford District—which spurred the suit in the first place-has actually worsened, while spending in the district has increased fairly dramatically. ${ }^{63}$

What the national experience with busing demonstrates, and what the Connecticut experience confirms, is quite straightforward: A great deal of

59. Sheff v. O'Neill, 678 A.2d 1267 (Conn. 1996). For a discussion of the decision and some of the commentary about Sheff, see James E. Ryan, Sheff, Segregation, and School Finance Litigation, 74 N.Y.U. L. REV. 529 (1999).

60. The Governor, for example, said a few days after the decision that "[a]s long as I'm governor, [busing] will not be one of the options." Robert A. Frahm, Court Orders Desegregation; Rowland Rules Out Busing, Vows To Keep Local School Control; Legislature, Governor Left To Manage Remedy, HARTFORD COURANT, July 10, 1996, at Al. For descriptions of similar reactions by state and local officials, see Ryan, supra note 59, at 566-67 \& n.117.

61. See Ryan, supra note 59, at 567 \& n.119; Jeff Archer, Opposing Sides Agree Conn. Integration Efforts Need More Money, EDuc. WK., Jan. 10, 2001, at 23.

62. In the 2000-2001 school year, for example, fewer than 2000 students (out of 540,000 in Connecticut) participated in the state's "open choice" plan, which allows for interdistrict transfers. Rick Green, Desegregation Effort Called "Dismal": Analysts Say Racial Isolation in Schools Is Getting Worse, HARTFORD COURANT, Aug. 7, 2000, at A3 [hereinafter Green, Desegregation Effort]; Rick Green, Out-of-Town Schools Draw Support; Many Parents Like Racial Balance Idea, HARTFORD COURANT, Apr. 20, 1999, at Al [hereinafter Green, Out-ofTown Schools]. The open choice plan does not currently meet demand for interdistrict transfers, see Green, Desegregation Effort, supra, and the low enrollment figures are due in part to the fact that "[f]ew suburban districts allocate more than a few dozen seats for the program, and many allocate none," Green, Out-of-Town Schools, supra. An additional 6400 students attend regional magnet schools, but here, too, demand outstrips supply. See Archer, supra note 61; Rick Green, Magnet Schools Drawing a Crowd; Demand Is High, but Funding Falls Short, HARTFORD COURANT, Apr. 22, 2001, at A1.

63. See Robert A. Frahm, Sheff Plaintiffs Back To Prod Desegregation, HARTFORD COURANT, Dec. 29, 2000, at A1. 
opposition to forced interdistrict integration endures. At the same time, outside of a few civil rights groups, there is not much organized support for it. Black parents, who might be the most natural supporters of interdistrict busing, have always been divided on the issue, with a large number opposing a policy that forced their children to take long rides to distant schools. With strong opposition and weak support, it is little wonder that mandatory interdistrict busing has occurred in very few jurisdictions and that even voluntary interdistrict busing plans are relatively rare and uniformly modest. ${ }^{64}$ Put simply, the Supreme Court in 1972 helped halt desegregation when it reached the suburban border, and very few courts or legislatures have managed to open that border since. Suburban school districts have thus been able to remain physically independent of urban school districts. As the next Subsection describes, they have also been able to remain financially independent.

\section{School Finance Reform}

Almost all school finance systems rely on a mixture of state and local revenue, with localities funding the bulk of their contributions through property tax revenues. ${ }^{65}$ Inequalities arise because localities have differing amounts of property wealth and thus can raise disparate amounts of funding for schools with similar property tax rates-that is, the greater the property wealth, the easier it is to raise funds for schools. States make varying efforts to equalize funding, but the persistence of inequalities, not to mention the persistence of funding suits, demonstrates that such efforts typically fall short. ${ }^{66}$

School finance litigation began at a time when many civil rights advocates were growing frustrated with the slow and uneven pace of school desegregation. Advocates hoped that by attacking funding inequalities, they would be able to improve the education available to poor and minority students. Like desegregation proponents, early school finance reformers essentially proposed a tying strategy. Whereas school desegregation would tie the fate of white and black students together by placing them in the same

64. For a discussion of voluntary interdistrict integration plans, see infra notes $108-109$ and accompanying text.

65. For an overview of school finance systems, see Allen R. Odden, School Finance and Education Reform, in RETHINKING SCHOOL FINANCE 1 (Allen R. Odden ed., 1992).

66. For a discussion of the cause of inequalities and states' responses to them, see U.S. GEN. ACCOUNTING OfFice, SCHOOL Finance: STATE EFFORTS TO EQualize Funding BETweEN WEALTHY AND POOR SCHOOL DISTRICTS (1998). See also Peter Enrich, Leaving Equality Behind: New Directions in School Finance Reform, 48 VAND. L. REV. 101, 104-05 (1995) (describing variations in property wealth among school districts, along with reliance on property taxes for school funding, as sources of expenditure variations among districts). 
schools, school finance equalization would tie the fate of poor and wealthy schools together by ensuring equal access to resources. ${ }^{67}$

The Supreme Court put an early end to school finance litigation in the federal courts by ruling in San Antonio Independent School District v. Rodriguez that unequal school funding schemes do not violate the U.S. Constitution. ${ }^{68}$ Despite the early blow it inflicted, Rodriguez did not end school finance litigation but redirected it. Advocates turned their attention to state constitutions and state courts, where they have experienced mixed results. Since 1974, litigants have challenged the finance schemes in over forty states, and nearly twenty state supreme courts have declared their respective school funding programs unconstitutional. ${ }^{69}$ Prior to 1989 , those challenging school finance systems primarily sought equalization of resources. ${ }^{70}$ Since 1989 , however, adequacy-based challenges have largely supplanted equality-based claims. Most litigants now contend not that all students are entitled to the same resources, but rather that all students should receive the funds necessary to finance an adequate education. ${ }^{71}$

Much has been and could be said about these cases. ${ }^{72}$ For our purposes, two features of this litigation bear emphasis. The first has to do with the remedies that have been provided, and the second has to do with the changing nature of the claims that have been brought. As for the remedies, the most remarkable feature of school finance litigation is that even successful challenges have not led to equal funding, nor have any of the suits done much to alter the basic structure of school finance schemes. ${ }^{73}$ Indeed, only two states-Nevada and Hawaii-have finance systems that could be described as providing equal funding to all districts, and Hawaii hardly counts given that there is only one school district for the entire state. ${ }^{74}$ Inequalities caused by differing property values thus continue to

67. See Ryan, supra note 20, at 259-60. See generally Michael Heise, Equal Educational Opportunity, Hollow Victories, and the Demise of School Finance Equity Theory: An Empirical Perspective and Alternative Explanation, 32 GA. L. REV. 543, 553-57 (1998) (discussing how school desegregation and finance litigation share critical structural aspects); Ryan, supra note 59. at 563-64 (same).

68. San Antonio Indep. Sch. Dist. v. Rodriguez, 411 U.S. 1 (1973).

69. For descriptions of, and citations to, the cases, see Ryan, supra note 20 , at 266-69 \& nn. 70-86.

70. See Enrich, supra note 66, at 121-40; Michael Heise, State Constitutions, School Finance Litigation, and the "Third Wave": From Equity to Adequacy, 68 TEMP. L. REV. 1151, 1152-53 (1995).

71. See Ryan, supra note 20, at 268-69 (describing the shift in theories and pointing out that not all cases since 1989 have shifted from equity to adequacy claims).

72. For an excellent overview of the cases and discussion of the commentary, see Enrich, supra note 66.

73. There is a good deal of disagreement in the literature regarding the precise impact of court decisions on school funding. See Heise, supra note 67, at 585-628. There is no disagreement, however, regarding the central point made in the text: No school finance suit has led to equalized funding among school districts in any state.

74. For a discussion of Hawaii's finance scheme, see John A. Thompson, Notes on the Centralization of the Funding and Governance of Education in Hawaii, 17 J. EDUC. FIN. 286 
exist in nearly every state, even in those states whose courts have ordered equalization. ${ }^{75}$

The reason is not hard to fathom. In order to equalize funding, legislatures would have to do one of two things: Raise all districts to the level of the highest-spending ones, or bring districts down to a specified level and essentially cap any spending beyond that level. The first option is financially impractical in most states. ${ }^{76}$ The second option is financially possible, but it is so controversial that it is politically infeasible. ${ }^{77}$

The controversy stems from the fact that equalizing funding by controlling local spending requires a cap on local spending or the recapturing of some locally raised revenues. Neither measure is politically popular, to say the least. Local citizens, and especially parents, do not like to be told that they cannot raise and spend local revenues on their own schools. ${ }^{78}$ They especially dislike the idea that locally raised revenues might be recaptured and redistributed to the rest of the state. ${ }^{79}$ Indeed, in places like Texas, Kansas, and Vermont, recapture plans-dubbed "Robin Hood" schemes-have provoked continued and intense political squabbling, public protests, and litigation. ${ }^{80}$ Donor districts in Kansas and Texas, for example,

(1992). For a discussion of Nevada, see U.S. GEN. ACCOUNTING OFFICE, supra note 66, at 26. Nevada does not guarantee that all districts will have the same funds; rather, in Nevada (and only in Nevada) all districts can raise the average per-pupil funding amount at the same tax rate. See id.

75. See U.S. GEN. ACCOUNTING OFFICE, supra note 66, at 2-8; see also Kirk Vandersall, Post-Brown School Finance Reform, in STRATEGIES FOR SCHOOL EQUITY, supra note 6, at 11, 17-18 (discussing studies indicating little improvement in funding equity during the 1980s, despite successful school finance litigation).

76. See Enrich, supra note 66, at 156 (noting that "bringing all districts up to the spending or service level of the top districts would be prohibitively expensive in most states"); Thomas Vitullo-Martin, Charter Schools and Tax Reform in Michigan, in STRATEGIES FOR SCHOOL EQUITY, supra note 6, at 115, 121-22 (calculating that it would cost Michigan an additional \$7 billion in state aid (which would double state spending) to bring all districts up to the level of the wealthiest districts).

77. For a discussion of the political difficulties raised by limiting spending or redistributing locally raised revenues, see Enrich, supra note 66, at 157-59; Margaret E. Goertz, Steady Work: The Courts and Reform in New Jersey, in STRATEGIES FOR SCHOOL EQUITY, supra note 6, at 101, 111-13; and Molly S. McUsic, The Law's Role in the Distribution of Education: The Promise and Pitfalls of School Finance Litigation, in LAW AND SCHOOL REFORM 88, 108-15 (Jay P. Heubert ed., 1999).

78. Consider, for example, the recent controversy generated when school board officials initially refused to let parents in Greenwich Village raise funds to keep a popular teacher on the staff at a local school; the parents eventually won this battle. See NYC Parents, Willing To Pay Teacher's Sulary, Get To Keep Her, CNN, Sept. 26, 1997, at http://www.cnn.com/US/9709/26/ teacher.uproar. Consider, as well, the fact that parents in wealthy suburbs have established private foundations to supplement government funding for schools and to avoid court-imposed spending limitations. See FISCHEL, supra note 5, at 156; Richard Rothstein, Assessing Money's Role in Making Schools Better, N.Y. TimEs, Nov, 14, 2001, at D12.

79. For a discussion of this point, see William H. Clune, New Answers to Hard Questions Posed by Rodriguez: Ending the Separation of School Finance and Educational Policy by Bridging the Gap Between Wrong and Remedy, 24 CONN. L. REV. 721, 731, 739 (1992); and Enrich, supra note 66, at $156-59$.

80. For discussions of legislative reactions in Texas, see Albert Cortez, Power and Perseverance: Organizing Change in Texas, in STRATEGIES FOR SCHOOL EQUITY, supra note 6, 
sued their respective states, contending that the states had taken the districts' property without compensation. ${ }^{81}$ Some donor districts in Kansas even considered seceding from the state.$^{82}$ In Vermont, protestors purchased the station wagon owned by the chief sponsor of the finance plan, parked it near the state capitol, and allowed passersby to demonstrate their opposition to the plan by sledge-hammering the car. ${ }^{83}$

Given the strong opposition to spending caps and recapture plans, it is not surprising that almost no school finance systems-even those reformed in response to a court order-limit the amount that local districts can raise. ${ }^{84}$ Similarly, very few rely on explicit recapture provisions. ${ }^{85}$ States typically respond to court orders by increasing state aid to poorer districts. ${ }^{86}$ States usually hold aid to wealthier districts constant or increase it at a slower rate than aid to poorer districts, ${ }^{87}$ but wealthier districts are typically allowed to use their own revenues to spend more than the poorer districts can afford ${ }^{88}$ Providing more state aid to poorer districts while holding such aid to wealthier districts constant is, of course, redistributive, and it is often controversial. ${ }^{89}$ But the controversy generated by this response is nowhere near as intense as that created by recapture provisions. This is a point that legislatures will have to bear in mind when and if they determine how to finance interdistrict school choice plans, as such plans have the potential to be retail versions of general recapture plans, where local money is diverted to neighboring districts, private schools, or nonresident transfer students.

at 181; Mark Yudof, School Finance Reform in Texas: The Edgewood Saga, 28 HARV. J. ON LEGIS. 499 (1991); and Sam Howe Verhovek, Texans Reject Sharing School Wealth, N.Y. TIMES, May 3, 1993, at A12. For Kansas, see FISCHEL, supra note 5, at 120-21. For Vermont, see Joetta L. Sack, In Vermont's Funding Shakeup, a Bitter Pill for the “Gold Towns," EDUC. WK., Oct. 28, 1998, http://www.edweek.org.

81. See Unified Sch. Dist. No. 229 v. State, 885 P.2d 1170, 1194-96 (Kan. 1994) (concluding that recapture did not constitute an impermissible taking of property); Bess Keller, Districts File Lawsuit Against Texas' School Finance System, EDUC. WK., Apr. 18, 2001, at 26 (describing a suit filed by "[f]our Texas school districts that were forced by state law to share their tax revenue with poorer districts").

82. See John Augenblick, The Role of State Legislatures in School Finance Reform: Looking Backward and Looking Ahead, in STRATEGIES FOR SCHOOL EQUITY, supra note 6, at 89, 98.

83. See Sack, supra note 80.

84. See Augenblick, supra note 82, at 93 (noting that "Colorado and Washington are among the very few states that place limits on how much revenue school districts can choose to raise on their own").

85. See id.; Enrich, supra note 66, at 158; McUsic, supra note 77, at 111; see also Gittell, supra note 6, app. 1, at 70-83 (listing legislative school finance reforms current to 1997).

86. See U.S. GEN. ACCOUNTING OFFICE, supra note 66, at 20-29 (discussing state efforts at equalization); William N. Evans et al., Schoolhouses, Courthouses, and Statehouses After Serrano, 16 J. POL'Y ANALYSIS \& MGMT. 10, 12 (1997) (concluding from a study of litigation and legislative responses that "[c]ourt-ordered reform reduced inequality by raising spending at the bottom of the distribution while leaving spending at the top unchanged").

87. Evans et al., supra note 86 , at 12 .

88. Enrich, supra note 66 , at 158 .

89. The long-running controversy in New Jersey is probably the most well-known example. For an insightful discussion of the school finance saga in that state, see Goertz, supra note 77 
The second, related feature of school finance litigation worth emphasizing is the transition in litigation strategies from equalization claims to adequacy claims. Legislators are not the only ones to have recognized the political difficulty in equalizing resources. Advocates have as well, and they have generally altered the goal of school finance litigation. Instead of seeking equal funding or equal access to resources, most school finance suits now seek sufficient resources to fund an adequate education. ${ }^{90}$

A number of considerations prompted the switch in strategies and goals, including the fact that strict equality of resources could actually harm some urban districts, whose property values are higher than the state average. ${ }^{91}$ It seems clear, however, that one important consideration was political. Seeking adequate instead of equal resources is politically less controversial, as it does not raise the specter of leveling down through spending caps or recapture provisions. Adequacy arguments are thus "less threatening" than equality arguments because they do not interfere with local control over resources or the ability of wealthy districts to retain a superior position. ${ }^{92}$ Perhaps because they are less threatening, adequacy suits have proven more successful in court than have equality suits. ${ }^{93}$

Even successful adequacy suits, however, presuppose that existing funding inequalities will remain. More precisely, adequacy suits abandon the idea of tying districts together financially by requiring access to equal resources. Those districts that can fund a more-than-adequate education are free to do so. While not all of these districts are in the suburbs, the vast majority are. The progression of school finance suits has thus paralleled the progression of desegregation suits, in that both reforms have preserved the boundaries between urban and suburban districts. Indeed, the parallel between adequacy suits and Milliken II relief is quite striking: Both channel resources to poor, often urban, districts while protecting the independence and sanctity of wealthy, usually suburban, districts.

The desegregation and school finance experiences, we suggest, offer some important insights into the prospects for school choice plans, both public and private. It seems clear from the experience with desegregation, stretching from the busing crises to the Sheff decision, that suburban districts and their legislators can be expected to resist any attempt to join them forcibly with urban districts. One would therefore expect that most suburban districts would oppose any choice plan-be it public or privatethat requires suburban schools to accept interdistrict transfers. Such a plan

90. See Heise, supra note 70, at 1162-66; Ryan, supra note 20, at 268-69.

91. See Heise, supra note 67, at 579-84.

92. Enrich, supra note 66, at 168-69; see also McUsic, supra note 77, at 119 (arguing that adequacy claims have "political" advantages over equality claims, including the fact that "[u]nder adequacy claims, [wealthy] districts remain free to exploit their local property wealth in pursuit of educational excellence").

93. See Ryan, supra note 20, at 268-69. 
would be little different from a one-way mandatory interdistrict busing plan. At the same time, efforts to reform school finance suggest that it will be politically difficult to force localities to use local revenues to fund interdistrict choice plans, as such plans would be functionally similar to recapture provisions that require the redistribution of locally raised school revenues. ${ }^{94}$ The dynamics of school finance reform and the politics of desegregation thus suggest that local districts will rarely be forced to accept outsiders or to divert local revenues to private schools or schools outside of their districts. This will obviously limit the options available to students.

Taken together, then, experience with school desegregation and school finance reform suggests that school choice plans are likely to be fairly limited in scope and ambition. Politically, school choice seems most likely to succeed when it is confined to districts where there is not a great deal of attachment to neighborhood schools, which is most likely to be true in urban districts where neighborhood schools are not very good. Even within urban districts, however, there may be opposition to school choice if some neighborhood schools are much better than others. The dynamic between suburban and urban districts that we describe thus may also exist within some urban districts, making widespread intradistrict choice plans politically difficult to adopt and implement there. Any effort to extend choice beyond a particular district or to include private schools will be even more difficult politically, in large part because such plans threaten (or will be perceived to threaten) suburban schools. What we should expect to see, in short, are scattered, geographically constrained choice plans in urban areas with a large number of inadequate schools. What we should not expect to see, unless some significant political changes occur, are statewide or even robust regional choice plans. Although school choice is in what one could call the toddler years, the emerging pattern conforms to these expectations.

\section{B. The Shape of School Choice}

Formal school choice plans come in four main varieties: intra- and interdistrict public school choice, charter schools, and voucher plans. Although vouchers for private schools generate the most controversy and have attracted the most attention, they represent a tiny portion of the existing school choice universe. Most school choice currently occurs among public schools. Moreover, within the realm of formal public school choice plans, most students choose among schools within one district. The largest

94. Cf. Vitullo-Martin, supra note 76 , at 122 (arguing that, "in political reality," the state could not force local districts to pay the costs of out-of-district students attending local charter schools). 
school choice "program," of course, is not formalized at all, but rather occurs when parents select where to live based on the quality of public schools in a residential area. ${ }^{95}$ The existence of this type of school choice, which by conservative estimates encompasses at least twenty-five percent of public school students, is widely recognized but rarely discussed. ${ }^{96}$ The fact that such a large number of parents-including the overwhelming majority of well-to-do parents-have already exercised a form of school choice, however, is a crucial starting point in understanding the shape of current school choice plans as well as the political dynamics surrounding proposals to expand school choice.

\section{Intradistrict Public School Choice}

The next most popular form of school choice, after what could be called residential school choice, allows students to attend a nonneighborhood school within a single school district. Approximately four to five million students are involved in intradistrict choice plans. ${ }^{97}$ Although this number dwarfs the number of students involved in other types of school choice, it still only encompasses approximately eight percent of all public school students. ${ }^{98}$ Even this relatively modest figure may give a misleading impression regarding the degree of choice made available in intradistrict plans, most of which are designed to protect the neighborhood school.

There are three types of intradistrict plans. By far the most popular offers students the opportunity to attend one or more specialized schools within a district. These schools tend to offer alternative or accelerated programs and often use selective admission criteria. Famous examples include the Boston Latin School, Bronx Science, and Lowell High School in San Francisco..$^{99}$ In addition, a number of districts have created magnet schools to foster voluntary racial integration. ${ }^{100}$ Like traditional alternative schools, magnet schools typically offer specialized programs or curricular

95. Martha Minow, Choice or Commonality: Welfare and Schooling After the End of Welfare as We Knew It, 49 DUKE L.J. 493, 506 n.34 (1999).

96. For an exceptional discussion of residential school choice, including discussion of the estimated number of families exercising such choice, see Jeffrey R. Henig \& Stephen D. Sugarman, The Nature and Extent of School Choice, in SCHOOL CHOICE AND SOCIAL CONTROVERSY 13, 14-17 (Stephen D. Sugarman \& Frank R. Kemerer eds., 1999).

97. Id. at 17; see also NAT'L CTR. FOR EDUC. STATISTICS, U.S. DEP'T OF EDUC., ISSUE Brief No. IB-9-96, PUblic SCHOOL CHOICE PROGRAMS, 1993-94: AVALlabILITY AND STUDENT PARTICIPATION 2 (1996) (providing other relevant statistics).

98. Henig \& Sugarman, supra note 96 , at 32 n.8.

99. See id. at 18 .

100. One study reports that 1.2 million students attended magnet schools in 1991, most of them within their home districts, most of which were urban districts. Rolf K. Blank et al., After 15 Years: Magnet Schools in Urban Education, in WHO CHOOSES? WHO LOSES? CULTURE, INSTITUTIONS, AND THE UNEQUAL EFFECTS OF SCHOOL CHOICE 154, 157-58 (Bruce Fuller \& Richard Elmore eds., 1996). 
themes. Because they are designed to encourage racial integration, they often employ racial balance criteria in selecting students. ${ }^{101}$ Although specialized or magnet schools obviously increase the public school options available to students and parents, these programs do nothing to alter the traditional organization and structure of public schooling: The default in these districts is that students are assigned to neighborhood schools. This default further suggests that there may be resistance to widespread choice plans even within urban districts, especially if those districts are residentially segregated by race and income and feature schools that range in quality.

A more far-reaching but much less prevalent type of intradistrict choice plan requires all parents within a district to select a school for their children. Students are not assigned to neighborhood schools, and there is no guarantee that parents who choose a neighborhood school for their children will receive their first choice. Parents typically list several choices among district schools, and school officials then make the final assignments, usually with an eye toward creating racially or socioeconomically integrated schools..$^{102}$ While confined to single districts, these controlled choice plans are nonetheless fairly radical in their departure from the traditional neighborhood assignment plan. They are also, probably for that reason, quite rare. Developed first in Cambridge, Massachusetts, in 1981, such plans currently exist in little more than a handful of districts nationwide. ${ }^{103}$

Rounding out the intradistrict picture are districts that allow for individual student transfers out of neighborhood schools. These programs can either be formalized, such as the one in New York City, or remain fairly informal, with principals of neighborhood schools retaining a good deal of discretion as to whether to accept nonneighborhood students. ${ }^{104}$ In either case, first priority is given to neighborhood children. In New York, for example, students are allowed to choose any public school, but crosscommunity transfers are allowed only when space is available. Given that most public schools in New York are already overflowing with neighborhood kids, there is usually no space for outsiders, rendering school choice in this context more theoretical than real for the overwhelming majority of New York public school students. ${ }^{105}$

101. Henig \& Sugarman, supra note 96 , at 18. For an analysis of the constitutional dimensions of racial ceilings in the education context, see Michael Heise, An Empirical and Constitutional Analysis of Racial Ceilings and Public Schools, 24 SETON HALL L. REV. 921 (1993).

102. For a discussion of these "controlled choice" plans, see HENIG, supra note 22, at 11112; KAHLENBERG, supra note 23, at 116-30; and VITERITTI, supra note 23, at 58-60.

103. See HENIG, supra note 22, at 111-12; Henig \& Sugarman, supra note 96, at 19.

104. See Henig \& Sugarman, supra note 96, at 20.

105. See id. 


\section{Interdistrict Public School Choice}

A large gap between theory and reality also plagues interdistrict choice programs. These programs come in two varieties: statewide open enrollment plans and more targeted urban-suburban choice plans created to foster racial integration. Neither type of plan has led to much movement across district boundaries. Indeed, despite what might seem like a large number of programs, the number of students participating in interdistrict choice is minuscule. As of 1993, only about 200,000 students nationwide were involved in such plans; that figure represented less than one-half of one percent of all public school children. Although growing rates of participation have since been reported in various states, the figures remain tiny and suggest that participation is still limited to less than one percent of all public school students. ${ }^{106} \mathrm{~A}$ closer look at the open enrollment and urban-suburban choice plans reveals several structural limitations that help protect the autonomy of suburban districts and simultaneously depress participation rates.

On paper, seventeen states and the District of Columbia have open enrollment plans, which ostensibly allow students to attend any school within the state. ${ }^{107}$ Minnesota began this trend in the late 1980s and has since been followed by seventeen other states, most of which created their plans in the early $1990 \mathrm{~s} .{ }^{108}$ Despite the promise of open enrollment statewide, a number of formal restrictions and practical obstacles limit the options available to students. The most important restriction, at least for purposes of this Article, is that participation in most state plans is at least partially optional.

Local districts in all but four states can decide whether or not they wish to participate as receiving districts; fewer states (but still a majority) allow districts to control exit from as well as entry into the district. ${ }^{109}$ All plans, moreover, give first priority to students living within a desired district to attend the district's schools. That is, no plans require districts to accept students unless space is available. ${ }^{110}$

From a historical perspective, it is not surprising that the plans are structured this way. That almost all open enrollment plans are voluntary and

106. The figures in this paragraph are taken from id. at 22,29 .

107. See NinA ShoKRAII REES, SCHOOL CHOICE 2000, at xxii (2000) (listing states).

108. See HENIG, supra note 22, at 112-13. For an excellent description of various states' open enrollment plans as of 1993, see LOUANN BIERLEIN ET AL., A NATIONAL REVIEW OF OPEN ENROLLMENT/CHOICE (1993).

109. See BIERLEIN ET AL., supra note 108, at B1-49; see also Henig \& Sugarman, supra note 96, at 21 (noting that in Ohio, where districts have the option of participating or not, "the major urban school districts have opted not to participate for fear of losing far more students than they could expect to attract").

110. BIERLEIN ET AL., supra note 108, at B1-49. 
allow districts to reject incoming transfers is understandable when considered within the context of interdistrict desegregation. In light of the intense opposition to mandatory interdistrict integration, it would be odd for state legislatures to require districts to accept out-of-district transfer students. It is thus probably no coincidence that the states that require districts to accept transfer students-Iowa, Nebraska, Utah, and Washington-had limited experience with school desegregation."' In addition, that all plans, even the few mandatory ones, allow for transfers only if space is not already taken by resident students is consistent with the traditional preference for neighborhood schools. Indeed, this feature is similar to the one that exists in those districts that allow intradistrict transfers only if space is not already taken by neighborhood residents. ${ }^{12}$

These structural limitations obviously reduce the options available to students. In some states, the majority of districts simply have opted out of the program. ${ }^{113}$ In other states, more districts formally participate in open enrollment programs, but the fact that districts will nonetheless accept transfer students only when space is available restricts the actual number of possible transfers. We have been unable to find data regarding the actual or reported capacities of districts, so it is difficult to assess with any precision how many transfer options are available in the various states. It is therefore hard to gauge whether the remarkably low participation rates are due more to lack of space or to lack of interest. Undoubtedly space constraints and personal preferences both play a role in limiting participation, but it is impossible to tell without more data which factor is more important.

There is good reason to suppose, however, that at least relatively highspending districts have an incentive to limit or block the transfer of students into their districts. As discussed above, school financing is organized by district, and disparities exist among different districts. Interdistrict transfers thus pose more complicated financial (and political) questions than do intradistrict transfers. ${ }^{114}$ Although funding schemes for interdistrict plans

111. See id. at B20-21 (Iowa); id. at B31-32 (Nebraska); id. at B41 (Utah); id. at B44-45 (Washington). For more information about the demographics of public schools in these four states, including in their urban school districts, see Bess Keller, No Strings Attached, EDUC. WK., Jan. 8, 1998, at 153, discussing lowa; Bess Keller, Walking Softly, EDUC. WK., Jan. 8, 1998, at 195, discussing Nebraska; Mark Walsh, Small City, Big Issues, Educ. WK., Jan. 8, 1998, at 254 , discussing Utah; and Jeanne Ponessa, A United Way, EDUC. WK., Jan. 8, 1998, at 262, discussing Washington.

112. See supra Subsection I.B.1.

113. See BIERLEIN ET AL., supra note 108, at BIl (reporting that, in Arkansas, as of 1993, only 163 out of 319 districts were participating); David J. Armor \& Brett M. Peiser, Interdistrict Choice in Massachusetts, in LeARNING From SCHOOL ChOICE 157, 160 (Paul E. Peterson \& Bryan C. Hassel eds., 1998) (reporting that as of 1995-1996, only eighty-nine of Massachusetts's 331 districts accepted transfer students).

114. For an insightful discussion of some of the financing difficulties-as well as some of the potential benefits-surrounding interdistrict choice plans, see Stephen D. Sugarman, School 
vary in their details, states typically allow state aid to follow the student, but states usually do not cover the local district's share of school funding. Because incoming students represent additional costs, receiving districts, especially high-spending districts, have an incentive to reject transfer students. Such districts can act on that incentive either by formally opting out of a state's interdistrict plan or by claiming not to have space available for transfer students. ${ }^{115}$ The latter option seems readily available, given that states do not seem to monitor district capacity and instead allow districts simply to self-report regarding available space. ${ }^{116}$ This structure conforms to what one would expect from the experience with school finance reform: Local districts are rarely required to spend local revenues on students exiting local districts or transferring in from neighboring districts.

Even where space is available, additional limitations in most state plans make exercising choice practically difficult. Most states do not provide funds for transportation. ${ }^{117}$ Parents who wish to exercise choice are responsible for transporting their children either to the out-of-district school or to the district boundary lines. Although some states provide transportation subsidies for low-income students, these subsidies often come in the form of reimbursements, requiring parents first to pay the costs of transportation. ${ }^{118}$ In addition, not all states require parents to receive information about the existence of interdistrict choice programs, let alone the availability of transportation subsidies. ${ }^{119}$

In most states, therefore, exercising interdistrict choice is not for the faint of heart. Because some districts may have opted out and others may report no available space, options for parents interested in sending their children to another district may be limited in the first instance. Where options remain available, parents who wish to participate in open enrollment plans must be motivated to learn about those options and have the time and resources to help transport their children to school. Obviously, not all parents would send their children to other districts even if doing so were easier, but clearly the existing interdistrict choice plans are not

Choice and Public Funding, in SCHOOL CHOICE AND SOCIAL CONTROVERSY, supra note 96, at I11, 119-21.

115. Cf. Henig \& Sugarman, supra note 96, at 21 (noting that "in practice ... receiving districts can probably block in-transfers they oppose by refusing to acknowledge that they have space available").

116. See BIERLEIN ET AL., supra note 108, at B1.

117. See id. at B2-3; HENIG, supra note 22, at 225.

118. See BIERLEIN ET AL., supra note 108, at B3 (noting that five states, as of 1993, reimbursed low-income parents for some transportation costs); Armor \& Peiser, supra note 113, at 160 (reporting that transportation subsidies for Massachusetts's open enrollment plan were available to low-income students through the receiving district).

119. Bierlein and her coauthors report that, as of 1993 , seven states required the distribution of data regarding open enrollment programs; they do not indicate whether those states specifically required that information about transportation subsidies be included. See BIERLEIN ET AL., supra note 108 , at $B 2$. 
designed to maximize interdistrict transfers. On the contrary, many plans seem more like gestures toward choice, designed as much to protect local district autonomy as they are to enhance parental or student autonomy.

Telling proof of this point is found in Minnesota, long hailed as a progressive pioneer in the territory of school choice. Although Minnesota has had an open enrollment plan for more than a decade, the NAACP recently sued the state on grounds similar to those presented in the Connecticut Sheff case. ${ }^{120}$ The plaintiffs argued that the de facto racial and socioeconomic segregation between the city of Minneapolis and the surrounding suburbs violated the city students' fundamental right to an adequate education, as guaranteed in the state constitution. ${ }^{121}$ The parties ultimately settled. The settlement requires eight suburban districts collectively to make 500 seats available for low-income city students each year for the next four years, and it also requires the state to pay for transportation costs. ${ }^{122}$ One of the striking aspects of this case is that it highlights the deficiencies in the existing open enrollment plan. Open enrollment in Minnesota existed on paper, but it obviously was not doing much to alleviate the racial and socioeconomic segregation between city and suburban districts. The plan failed in this regard, at least in part, because the state let it fail: It did not provide any funds for transportation, and state officials did not require suburban schools to accept inner-city students. ${ }^{123}$

Just as the case itself is striking, so too is the settlement. The plaintiffs initially argued that students in the Minneapolis metropolitan area should have the option to attend any public school in the region, ${ }^{124}$ but they ultimately settled for a modest increase in the existing open enrollment plan. ${ }^{125}$ Even this limited increase generated a good deal of controversy, with community members likening it to "forced busing" and protesting the

120. See KAHLENBERG, supra note 23 , at $175-77$ (discussing the litigation).

121. Id. at 175; see also Statement of Minneapolis NAACP and Parents (Feb. 19, 1999), at http://cfl.state.mn.us/naacp0219.htm (calling for open enrollment to end segregated, inadequate, and unequal education).

122. See Minneapolis Pub. Schs., NAACP Settlement Information, at http://www.mpls.k12. mn.us/news/news release/naacp5.shtml (last visited Apr. 8, 2002).

123. See HENIG, supra note 22, at 167 (noting that state officials in Minnesota "have been very wary about requiring suburban school districts to accept inner-city residents"). According to opponents of school choice in Minnesota, wealthy suburban districts tended to "exclude lowincome and minority students from nearby citics." COOKSON, supra note 3 , at 45 .

124. See Statement of Minneapolis NAACP and Parents, supra note 121 (proposing that parents in Minneapolis and the surrounding suburbs have the right to choose "to send their children to any suburban school or to any Minneapolis school").

125. In fairness to the plaintiffs, it must be noted that under the existing open enrollment plan, most students transferring to suburban districts from the city were white, and most of the students transferring to city schools were minorities. By targeting low-income city students for transfers to suburban schools, the settlement may help curtail or reverse the segregating effects of the open enrollment plan. See Anne O'Connor. School Settlement Aims To Reverse Trend Set Under Open Enrollment, STAR TRIB., Mar. 22, 2000, at IB. 
fact that local school revenues would be spent on outsiders. ${ }^{126}$ At the same time, however, that a settlement was reached at all suggests that there is some tolerance among suburban districts for at least limited enrollment by urban students. In these respects, the Minnesota settlement typifies the limited urban-suburban choice programs targeted to achieve racial diversity, which constitute the second type of interdistrict choice plan.

Some of these "plans" are not full-fledged plans as such, and do not claim to be, but rather involve the creation of one or more urban magnet schools that accept suburban students. There are currently over one million students in nearly 2500 magnet schools. ${ }^{127}$ Although most of these schools accept only resident students, some accept out-of-district students as well. ${ }^{128}$ Interdistrict magnet schools, like their intradistrict counterparts, are designed to foster racial integration and typically use racial balance criteria in selecting students, a move that has created both political and legal controversies. ${ }^{129}$

In addition to interdistrict magnet schools, a very small number of suburban districts participate in programs that allow a limited number of urban students to attend suburban schools. These include suburban districts surrounding Boston and Springfield, Massachusetts, Hartford, Rochester, Milwaukee, and St. Louis. ${ }^{130}$ All of the programs, except for the one in St.

126. See Minneapolis Pub. Schs., NAACP Settlement Questions and Answers, at http://www.mpls.k12.mn.us/news/news_release/naacp7.shtml (last visited Feb. 26, 2002).

127. See Blank et al., supra note 100 , at 157.

128. We have bcen unable to find precise figures on enrollment in interdistrict magnet schools. Given that there are no more than 250,000 to 300,000 students in all interdistrict programs combined, see supra note 106 and accompanying text, the figure must be below 300,000 .

129. Politically, magnet schools are controversial because they cost more to operate and restrict admissions, taking away resources from other public schools while simultaneously limiting the opportunities of resident students to attend the schools in order to assure racial balance. See KAHLENBERG, supra note 23, at 128-29; VITERITTI, supra note 23, at 57-58. Legally, magnet schools are controversial because the use of racial balancing criteria might be unconstitutional outside of a remedial context. See, e.g., Tuttle v. Arlington County Sch. Bd., 195 F.3d 698 (4th Cir. 1999) (holding unconstitutional the use of race in assigning students to magnet schools); Wessman v. Gittens, 160 F.3d 790 (1st Cir. 1998) (holding unconstitutional the use of race in selecting students for academically elite public schools). The constitutional question remains unsettled, though given its importance to both grade schools and universities, the Supreme Court will surely have to address it soon. See generally Note, The Constitutionality of Race-Conscious Admissions Programs in Public Elementary and Secondary Schools, 112 HARV. L. REV. 940 (1999).

130. For a discussion of the Boston and Springfield METCO programs, see SUSAN E. EATON, THE OTHER BOSTON BUSING STORY (2001); KAHLENBERG, supra note 23, at I52; and Armor \& Peiser, supra note 113, at 161-70. For a discussion of the Hartford and Rochester programs, see KAHLENBERG, supra note 23, at 151-52. Joseph Viteritti discusses the Milwaukee program, VITERITTI, supra note 23, at $98-99$, and the St. Louis program is the subject of a recent book, AMY STUART WELls \& ROBERT L. CRAIN, STEPPING OVER THE COLOR LINE: AFriCANAMERICAN STUDENTS IN WHITE SUBURBAN SCHOOLS (1997). In addition to these interdistrict programs, there are a number of metropolitan-wide districts, mostly in the South, that allow city residents the opportunity to attend suburban schools. See infra Subsection II.A.2 (discussing metropolitan districts). 
Louis, are very limited in scope. Boston's METCO program, which began in the 1960 s as a purely voluntary effort to promote racial integration, started with 220 students and involved only 3100 students by the year $2000 .{ }^{131}$ Hartford's program also began in the 1960s with 265 students, and by the 1980s involved a little more than a thousand students; it has expanded recently, but this has been in response to the Connecticut Supreme Court's unique decision in Sheff outlawing de facto school segregation. ${ }^{132}$ The programs in Rochester and Milwaukee are similarly small, involving roughly 600 and 5000 students, respectively. ${ }^{133}$

These programs are limited in scope not because of lack of demand. The programs have long waiting lists; indeed, the waiting lists in Boston and Rochester are four to five times larger than the number of students participating in the program. ${ }^{134}$ Instead, the scope of the programs is intentionally limited to ensure space for district residents or simply to preclude a large number of urban transfer students. Like open enrollment plans, none of these programs requires suburban districts to make space available by expanding facilities or increasing staff. ${ }^{135}$

The only (temporary) exception to this pattern, and the only relatively large-scale interdistrict choice program, existed in St. Louis. This program resulted from the settlement of a desegregation lawsuit, which many suburbanites reasonably believed would lead to the consolidation of suburban school districts with the St. Louis district. ${ }^{136}$ To avoid this result, sixteen suburban districts agreed to a "voluntary" interdistrict choice plan, which required them to accept transfer students, with a goal of increasing black enrollment to at least fifteen but no greater than twenty-five percent of the districts' total. The settlement also called for the creation of urban magnet schools. In the mid-1990s, this program was easily the largest of its kind in the country, involving 12,700 black students who transferred to suburban schools and 1500 white suburban students who attended urban magnet schools. The program was also quite expensive, as the settlement required the state to provide an "incentive payment" to suburban school

131. EATON, supra note 130 , at 4-5.

132. See KAHLENBERG, supra note 23, at 151-52; see also supra Subsection I.A.1 (discussing interdistrict choice in Connecticut).

133. KAHLENBERG, supra note 23, at 152; VITERITTI, supra note 23 , at 99.

134. The Rochester program serves 600 students, while 3000 are on the waiting list. KAHLENBERG, supra note 23, at 152. The Boston program serves 3100 , while 13,000 are on the waiting list. EATON, supra note 130, at 5-6; see also Anand Vaishnav, For Metco Students, the Ride Was Worth It, BOSTON GLOBE, June 8, 2001, at D13 (reviewing EATON, supra note 130).

135. As Susan Eaton observed in her study of Boston's METCO program, "METCO operates on terms that suburbanites can accept. It does not greatly alter the status quo of either suburbia's schools or their larger communities." EATON, supra note 130, at 221.

136. See Wells \& CRAIN, supra note 130, at 97-102 (describing the litigation and settlement, and explaining that the aggressive tactics of the district court judge led suburban residents to fear that a trial would ultimately result in their districts being consolidated with the St. Louis district). 
districts which equaled the per-pupil cost of transfer students. The settlement also required the state to pay for transportation, which in 1995 averaged a remarkable $\$ 2000$ per student. ${ }^{137}$

Although the St. Louis program was large relative to other interdistrict choice programs, it still involved fewer than one-fourth of the students in St. Louis and a much smaller fraction of suburban students. ${ }^{138}$ Many black parents in St. Louis simply chose to keep their children in St. Louis schools, and obviously the great majority of white suburban parents opted against sending their children to urban magnet schools. ${ }^{139}$ Suburbanites, meanwhile, at best tolerated the influx of transfer students. Even those sympathetic to the program repeatedly suggested, in words President Nixon would have appreciated, "that the millions of dollars the state pays to bring nearly 13,000 African-American students to suburban schools would be better spent 'fixing up' the city schools." ${ }^{140}$ It appears that suburbanites may soon get their wish, as the plan, which was never meant to be permanent, is being dismantled. State funding for the program will continue for another ten years, and the St. Louis school district will have to continue its magnet school programs indefinitely. Beginning in 2002, however, suburban school districts will no longer have to accept transfer students. ${ }^{141}$ Thus, in the end, even the most ambitious interdistrict choice program in the country bowed to suburban autonomy.

This is not to suggest that interdistrict choice in general or urbansuburban transfers in particular can never work. In some ways, the paucity of urban-suburban integration is an accident of local government law and tradition, as most school districts track municipal boundaries. In many places in the South, however, school districts encompass both cities and the surrounding suburbs. These metropolitan districts tend to be much more racially stable, have higher achievement levels, and have much higher approval ratings among parents than do urban-only districts, and they serve as examples of relatively successful urban-suburban integration. ${ }^{142}$ In addition, evidence suggests that parents who participate in interdistrict choice plans are quite satisfied with the plans, and the waiting lists in places like Boston and Rochester indicate that more parents would participate if

137. For this paragraph, see $i d$. at $99-105$.

138. See KAHLENBERG, supra note 23, at 153.

139. WELLS \& CRAIN, supra note 130 , at 151-79.

140. Id. at 336.

141. For a discussion of the dismantling of the St. Louis plan, see Caroline Hendrie, Settlement Ends St. Louis Desegregation Case, EDUC. WK., Mar. 24, 1999, http://www.edweek.org.

142. See, e.g., Orfield, supra note 57, at 832-33 (extolling the benefits of metropolitan desegregation plans); Gary Orfield \& David Thronson, Dismantling Desegregation: Uncertain Gains, Unexpected Costs, 42 EMORY L.J. 759 (1993) (same). 
they had the opportunity. ${ }^{143}$ There is also evidence that some suburban receiving districts in metropolitan choice or desegregation plans eventually came to accept and support at least limited urban-suburban integration. ${ }^{144}$ And there is evidence, finally, that the students from urban areas who transfer to suburban schools improve their academic achievement, as well as their academic aspirations, as compared to students who remain behind. ${ }^{145}$

Despite the intriguing success of some metropolitan districts and some interdistrict choice plans, students currently have quite limited opportunities to transfer from one district to another. The promise of interdistrict choice thus remains largely unfulfilled. ${ }^{146}$ Indeed, in recent years, interdistrict choice programs have been eclipsed by a remarkably popular new form of choice; charter schools. Perhaps not surprisingly, charter schools offer choices mostly within particular districts.

\section{Charter Schools}

A charter school is a cross between a public and a private school. ${ }^{147}$ Authorized by state statutes, the schools are publicly funded, tuition-free, nonsectarian schools that operate pursuant to a contract between the school and the chartering agency, which is either the local school board, a state agency, or a state-designated agency. ${ }^{148}$ The schools themselves can be newly created schools, converted public schools, or converted private schools. They can be opened and operated by any number of groups,

143. On parental satisfaction, see WELLS \& CRAIN, supra note 130, at 180-218; and Armor \& Peiser, supra note 113 , at 183.

144. See, e.g., Davison M. Douglas, Reading, Writing \& Race: The Desegregation OF THE CHARLOTTE SCHOOLS 215-54 (1995) (describing the success and community support of district-wide desegregation in the Charlotte-Mecklenburg Metropolitan School District); KAHLENBERG, supra note 23, at 153-55 (describing support for interdistrict desegregation plans in St. Louis, Wilmington, and Indianapolis); WELLS \& CRAIN, supra note 130, at 309-34 (describing reaction to the St. Louis plan); Orfield, supra note 57, at 845-46 (describing support for such programs in North Carolina).

145. See KAHLENBERG, supra note 23, at 151; Orfield, supra note 57, at 847. Although studies regarding academic achievement cannot perfectly control for self-selection bias and therefore must be interpreted with caution, a study of the St. Louis plan suggests that the schools themselves play an important role in influencing academic achievement. The study found that students who attended city magnet schools began with higher test scores than those who transferred to suburban schools, but that the latter eventually outperformed the former. WELLS \& CRAIN, supra note 130 , at 183-84.

146. EATON, supra note 130 , at 251 ("In the current discussions about school reform, while there is often polite mention of the benefits of diversity, the interdistrict efforts that would actually create that diversity are rarely explored.").

147. See generally Brunno V. Manno et al., Beyond the Schoolhouse Door: How Charter Schools Are Transforming U.S. Public Education, 81 PHI DELTA KAPPAN 736 (2000) (explaining the theory and structure of charter schools).

148. Id. at 737; see WcstEd \& U.S. Dep't of Educ., Overview of Charter Schools, at http://www.uscharterschools.org/pub/uscs_docs/gi/overview.htm (last visited Feb. 26, 2002). 
including teachers, parents, and private corporations, although some states require that the charter school creators be a nonprofit group. ${ }^{149}$ The schools are freed from complying with various regulations-relating to such issues as teacher hiring, curriculum, calendar, and length of school day-in exchange for accountability for performance. ${ }^{150}$ The core idea behind charters is to grant greater flexibility to schools in exchange for greater accountability, which includes the threat of closure if a school fails to perform adequately. ${ }^{151}$ Although the charter periods can vary between three and fifteen years, charters typically last for five years, after which the school must be reviewed before the charter is renewed. ${ }^{152}$

Unlike interdistrict choice plans, which have either grown slowly or withered, charter schools are the kudzu of school choice. Minnesota opened the first charter school in 1992. Four years later, in 1996, 178 charters were operating in seventeen states. ${ }^{153}$ Another four years after that, there were roughly 2000 charter schools operating in thirty-four states and the District of Columbia. ${ }^{154}$ The number of students attending charter schools grew exponentially during the same period. Starting from a few hundred in 1992 , enrollment in charter schools last year exceeded 500,000 students. ${ }^{155}$ This is twice the enrollment in charter schools just three years prior and is nearly twice the estimated number of students involved in interdistrict choice programs. ${ }^{156}$

Statutes authorizing charter schools, which now exist in thirty-seven states and the District of Columbia, vary a great deal in terms of funding, who can authorize charters, whether there are caps on the annual or total number of charters, and the degree to which charter schools are exempt from traditional school laws and regulations. ${ }^{157}$ Although these variations

149. Manno et al., supra note 147, at 737; see also U.S. DEP'T OF EDUC., THE STATE OF CHARTER SCHOOLS 2000, at 12 (2000), http://www.ed.gov/pubs/charter4thyear.

150. See Manno et al., supra note 147, at 737.

151. WestEd \& U.S. Dep't of Educ., supra note 148 ("The basic concept of charter schools is that they exercise increased autonomy in return for this accountability.").

152. Id.; U.S. DEP'T OF EDUC., supra note 149, at 12.

153. U.S. DEP'T OF EDUC., supra note 149, at 10-11. Also, in 1996, an additional seven states, for a total of twenty-five, and the District of Columbia enacted legislation authorizing charter schools. Id. at 10; see also Henig \& Sugarman, supra note 96, at 23.

154. Ctr. for Educ. Reform, Survey of Charter Schools 2000-2001, at http://www.edreform. com/charter_schools/report/survey01.html (last visited Feb. 26, 2002).

155. Ctr. for Educ. Reform, Charter School Highlights and Statistics, at http://www.edreform.com/pubs/chglance.htm (last visited Feb. 26, 2002).

156. For 1998 enrollment figures, see U.S. DEP'T OF EDUC., supra note 149, at 18. For interdistrict choice figures, sec Henig \& Sugarman, supra note 96, at 22.

157. See U.S. DEP'T OF EDUC., supra note 149, at 12. The Center for Education Reform (CER) classifies charter legislation generally as either strong (meaning the laws foster the development of numerous, independent charter schools) or weak (meaning the laws inhibit the development of charter schools or significantly limit their autonomy). Ctr. for Educ. Reform, Charter School Laws: State by State Ranking and Profiles, at http:/www.edreform.com/ charter_schools/laws/ranking.htm (last visited Feb. 26, 2002). For the CER's most recent 
make it precarious to generalize, charter statutes and charter schools do share certain common features that are relevant for our purposes. First, almost all charter schools enroll students from their home districts. ${ }^{158}$ This typically results from statutes restricting enrollment or granting a preference to resident students. Nine of the thirty-eight charter statutes explicitly limit enrollment to district residents. ${ }^{159}$ In all but two of the other states, residency preferences are allowed or required. ${ }^{160}$ Given that most charter schools report having a waiting list, it is reasonable to presume that residency preferences operate in practice to exclude at least some nonresidents. ${ }^{161}$ Finally, very few states provide funding for transportation of nondistrict residents to attend charter schools, which also works to limit attendance to resident students. ${ }^{162}$

The second common feature of charter statutes involves funding. The details of funding schemes vary from state to state, and they also vary within states, depending on whether the charter is granted by a local school board or by a state agency. ${ }^{163}$ In general, however, charter schools are financed by a combination of state and local aid. Public schools in districts in which charter schools are located thus stand to lose a portion of both

rankings, see Ctr. for Educ. Reform, Charter School Laws: Scorecard and Ranking (Oct. 2001), at http://www.edreform.com/charter_schools/laws/ranking_chart.pdf.

158. See Henig \& Sugarman, supra note 96 , at 23.

159. These include Fiorida, Georgia, Illinois, Mississippi, Missouri, New Mexico, Rhode Island, South Carolina, and Virginia. FLA. STAT. ANN. ch. 228.056(6)(a) (Harrison 1998 \& Supp. 2000); Ga. CODE ANN. \& 20-2-2066(a) (2001); 105 LlL. CoMP. STAT. ANn. 5/27A-4(d) (West 1998 \& Supp. 2001); Miss. CODE ANN. \& 37-28-1 (2001); Mo. ANN. STAT. \& 160.410 (West 2000); N.M. STAT. ANN. \$ 22-8B-4.1 (Michie 2000); S.C. CODE ANN. \$ 59-40-50 (Law. Co-op. 2001); VA. CODE ANN. § 22.1-212.6 (Michie 2000); Ctr. for Educ. Reform, Charter School Legislation: Profile of Rhode Island's Charter School Law, at http://www.edreform.com/ charter_schools/laws/RhodeIsland.htm (last visited Feb. 26, 2002). Other states have double standards: Locally granted charters may have to limit enrollment to district residents while stategranted charters may admit students statewide. See, e.g., MICH. COMP. LAWS ANN. \& 380.504 (West 1997).

160. See, e.g., CAL. Educ. CODE $\S 47605$ (West 1993 \& Supp. 2002) (“"II]f the number of pupils who wish to attend the charter school exceeds the school's capacity, ... [p]reference shall be extended to pupils currently attending the charter school and pupils who reside in the district ...."); OHIO REv. CODE ANN. $\$ 3314.06$ (Anderson 1999) ("[P]reference shall be given to students attending the school the previous year and to students who reside in the district in which the school is located."). Of the twenty-eight states that nominally allow statewide enrollment, only Nevada and Minnesota do not allow or require residency preferences.

161. As of 2000-2001, seven out of every ten charter schools had waiting lists. U.S. DEP'T OF EDUC., supra note 149 , at 1 .

162. Only two states, Connecticut and Massachusetts, provide limited state aid for transporting out-of-district students. CONN. GEN. STAT. $\$ 10-66 \mathrm{bb}(2001)$; MASS. GEN. LAwS ANN. ch. 71, $\$ 89$ (West 1996 \& Supp. 2001). Most statutes do not mention transportation.

163. In Arizona, for example, recipients of charters granted by local agencies may negotiate for funding in their contract with the locality. State-chartered schools, however, receive funding calculated by the same formula used to calculate aid to district schools. See ARIz. REV. STAT. ANN. § 15-185 (West Supp. 2001); see also LA. REV. STAT. ANN. § 17:3995 (West Supp. 2001) (establishing a similar two-track system of funding). 
state and local funds. ${ }^{164}$ This gives local school boards an obvious financial incentive to block charter schools; as one observer commented, allowing local boards to authorize charters is akin to allowing "the New York Times to decide whether the Wall Street Journal can sell papers in New York [C]ity." ${ }^{165}$ Perhaps not surprisingly, local school boards have proven more reluctant to grant charters than have other granting agencies. ${ }^{166}$ In districts where there is a good deal of support for existing public schools, obtaining a charter from a local school board is especially difficult, if not quixotic. ${ }^{167}$

This last point leads to the third and final common feature of charter schools, namely, their location. Most charter schools are located in urban school districts. A New York Times report in December 2000, for example, estimated that approximately two-thirds of all charter schools were located in cities. ${ }^{168}$ In some states, this concentration is mandated or encouraged by charter statutes. At least twelve statutes explicitly provide that authorizing agencies, whether local or state, should give priority to charter schools that serve poor, minority, or low-achieving students, and more often than not these students are located in urban districts. ${ }^{169}$ In two states, Ohio and Missouri, charter schools are by law allowed only in urban districts. ${ }^{170}$ In one other, Wisconsin, charters can more easily be opened in Milwaukee than elsewhere in the state, by virtue of the fact that charters can be authorized by several different agencies in Milwaukee but only by local school boards everywhere else. ${ }^{171}$ In addition to these statutory provisions

164. See, e.g., DEL. CODE ANN. tit. $14, \S 408$ (1999) (entitling charter schools to $100 \%$ of state and local per-pupil funding).

165. Lisa Black, Elective Excellence, School Officials Measure Responses to Non-Traditional Schools, CHI. TRIB., Aug. 30, 2000, Schaumberg \& Hoffman Estates, at 5.

166. As of 2000-2001, states requiring local approval had an average of 9.6 charters per state, while states with multiple chartering entities and strong appeals processes had an average of 80.8 charters per state. Ctr. for Educ. Reform, supra note 154.

167. The difficulty faced by those attempting to locate the Thomas Jefferson Charter School in the Chicago suburbs is perhaps the most egregious example. At least eleven suburban districts had rejected the proposal by June 1997. In Elk Grove Township, the district fought off the school for four years until, in 2000 , a court ruled in favor of the State Board of Education's decision to overtum the district's rejections. Noreen S. Ahmed-Ullah, District 59 May Drop Fight over Charter, CHI. TRIB., Nov, 22, 2000, Metro Northwest, at 1. The judge's decision, not surprisingly, was perceived by residents as a blow to local control. Becky Beaupre, Judge Permits First Suburban Charter School, CHI. SUN-TIMES, Sept. 30, 1998, at 14.

168. Kate Zemike, Suburbs Face Tests as Charter Schools Continue To Spread, N.Y. TIMES, Dec. 18, 2000, at Al.

169. ARK. CODE ANN. § 6-23-304 (Michie 1999 \& Supp. 2001); CAL. EDUC. CODE $§ 47605$ (West 1993 \& Supp. 2002); Colo. REV. STAT. ANN. § 22-30.5-109 (West 1998 \& Supp. 2001); CONN. GEN. STAT. § 10-66bb (2001); DEL. CODE ANN. tit. 14, § 503 (1999); D.C. CODE ANN. \$ 38-1702.1 (2001); 105 ILl. COMP. STAT. ANN. 5/27A-4 (West 1998); MASS. GEN. LAWS ANN. ch. 71, $\$ 89$ (West 1996 \& Supp. 2001); MO. ANN. STAT. $\S 160.405$ (West 2000); N.Y. EDUC. LAW \& 2852 (McKinney 2001); N.C. GEN. STAT. \$115C-238.29C (1999).

170. OHIO REV. CODE ANN. \$ 3314.013 (Anderson 1999) (limiting the total number of charter schools and eligible districts); MO. ANN. STAT. \& 160.400 (West 2000) ("Charter schools may be operated only in a metropolitan school district or in an urban school district . . ..").

171. WIS. STAT. ANN. $\$ 118.40$ (West $1999 \&$ Supp. 2001). 
that encourage or require the concentration of charters in failing, urban districts, constituent demand and local politics push in the same direction.

Suburbanites seem much less interested in charter schools, which undoubtedly has to do with the fact that suburban residents are generally more satisfied with their public schools than are urban residents and thus see less of a need for alternatives. ${ }^{172}$ In fact, news reports suggest that suburbanites see charter schools not only as unnecessary but as an insult to their public schools and a threat to suburban property values. ${ }^{173}$ As one resident of Glen Cove, a New York suburb, told a New York Times reporter, "We want to keep our community desirable. The connotation of a charter school is, 'The schools are lousy, they're not meeting the needs of our children.' Our property values will go down, our taxes will increase because we'll need to pay more money to keep up the standards." ${ }^{174}$ Another community member echoed this point. "There's nothing wrong with our public schools," she exclaimed, "and I take great offense to people coming in here and telling me otherwise." 175

Charter schools can send the same message in urban school districts, of course, and many urban leaders and educators also see charter schools as a threat to existing public schools. ${ }^{176}$ The difference, however, is that urban residents are generally more prepared than suburban residents to admit that their public schools are failing and that alternatives are needed. ${ }^{177}$ Urban educators, in turn, generally seem more willing to endorse alternatives, both because of a greater degree of desperation and because the large size of urban districts makes it easier to absorb a few charter schools. ${ }^{178}$ In addition, some educators see charter schools as a way of attracting middleclass residents back to city schools. The suburbs, by contrast, are generally already filled with middle-class residents, and charter schools may, because of the signals they send, drive some of them away. ${ }^{179}$

172. See, e.g., Black, supra note 165 (explaining that suburban Chicago communities are indifferent to charters, which are perceived as altematives to failing schools); Emily Wax, Alexandria Votes To Consider Charter Schools; Arlington Rejects Similar Plan, WASH. POST, Dec. 21, 2000, at B1 (noting that public meetings to discuss charter school proposals have been sparsely attended in Arlington and Alexandria due to lack of interest).

173. See, e.g., Editorial, Give Charters a Better Chance, CHI. TRIB., May 20, 1999, at 28 (suggesting that some suburban local school boards view charter schools as a threat to their authority and control).

174. Zernike, supra note 168.

175. Id.

176. See, e.g., Kit Wagar, Lawmakers Ponder Possible Removal of Accreditation, KAN. CITY STAR, Oct. 20, 1999, at B7 (noting that urban lawmakers argued that charter schools in Kansas City would weaken public schools).

177. See MOE, supra note 4, at 147-54 \& tbl.5-7 (explaining that among those most supportive of school choice are those who are interested in removing their children from the public schools they are attending).

178. See Zernike, supra note 168.

179. See id. (describing suburban residents' opposition to charter schools). 
Charter schools are thus an interesting political phenomenon. They draw broad and bipartisan support on the national level and in many state legislatures. ${ }^{180}$ Although the charter concept is generally popular, the assumption underlying much of the support appears to be that charter schools are mostly appropriate for students in failing, urban districts. They are rarely viewed or created as a means of offering significant opportunities for interdistrict school choice, ${ }^{181}$ and they are often greeted with hostility when proposed in suburban districts. Many thus see charter schools as an innovative, not to mention relatively low-cost, way of reforming failing urban school systems. In this sense, charter schools are quite similar to the few existing voucher plans.

\section{School Vouchers}

Publicly funded vouchers have for a while seemed right around the corner, but they have yet to arrive in force. Three limited programs have been created in the last decade, in Milwaukee, Cleveland, and Florida. ${ }^{182}$ All provide vouchers that can be used at private schools, including religious schools, and all have been challenged on constitutional grounds, though each is currently operating. ${ }^{183}$ Despite the lavish attention each program has received, very few students receive vouchers through them.

Milwaukee's program is the oldest and largest of the three. It began in 1990 and currently allows for a maximum of 15,000 vouchers to be distributed to low-income students, but as of last year, only a few more than 10,000 students took advantage of the plan. ${ }^{184}$ The Cleveland program

180. See, e.g., Peterson, supra note 4 , at 53 .

181. There are some limited exceptions, as some states allow out-of-district students to enroll in (at least) state-created charter schools. See supra notes 159-160 and accompanying text. A few other states allow for regional charter schools. See, e.g., ALASKA STAT. \& 14.03.265(b) (Michie 2000); MASS. Gen. LAWS ANN. ch. $71, \S 89$ (West 1996 \& Supp. 2001); PA. STAT. ANN. tit. 24, § 17-1718A (West 2001).

182. Much has been written about these plans. For a basic description of all three, see MOE, supra note 4, at 37-38; and Henig \& Sugarman, supra note 96, at 26-28. See also VITERITTI, supra note 23, at 98-113 (discussing the Milwaukee and Cleveland plans). In addition to these programs, Maine and Vermont provide money for students in rural districts too small to run their own schools to attend private schools, and many states pay the costs for at least some disabled students to attend private schools. See Sugarman, supra note 114, at 128-29, $138 \mathrm{n}$. 18. Although the Vermont and Maine plans have caught the attention of voucher supporters, see id. at 128 , vouchers for students in districts too small to run schools, like payments to private schools for disabled students, are tangential to the general battle over vouchers, and we treat them accordingly.

183. See Henig \& Sugarman, supra note 96 , at $26-28$. For a discussion of the various legal challenges that have been filed against the programs, see Alison Frankel, On the Way to a Supreme Court Test, AM. LAW., May 2000, LEXIS, Nexis Library, American Lawyer File.

184. See Bruce Fuller et al., SChOOl Cholce: ABundant HoPes, SCARCE EVIdeNCE of Results 62 (1999); Milwaukee Parental Choice Program Facts and Figures for 2001-2002 (2001), http://www.dpi.state.wi.us/dpi/dfm/sms/pdf/mpc0lfnf.pdf (noting that a total of 10,882 students were enrolled in the Milwaukec voucher program as of November 2001). 
began more recently and involved, as of 1998-1999, 3500 students. ${ }^{185}$ The Florida program is the newest and, as described above, offers vouchers to students in persistently failing schools. ${ }^{186}$ Since 1999 , the first year of its operation, only two schools met the "persistently failing" standard, and only fifty-two students accepted vouchers to attend private schools. ${ }^{187}$ At the moment, then, fewer than 15,000 students receive publicly funded vouchers, which is less than one-tenth of one percent of all elementary and secondary students and is smaller than the number of students currently receiving privately funded vouchers. ${ }^{188}$

More voucher plans have been rejected than passed. Though the rejections have been a disappointment to the plans' proponents, the rejected plans are as instructive as the few that have been adopted. Every proposal to provide vouchers on a large scale has failed. ${ }^{189}$ Between 1990 and 1993 alone, for example, fourteen state legislatures considered and ultimately rejected voucher proposals. ${ }^{190}$ Voucher or tax-credit initiatives also appeared on a number of state ballots in the 1990s, including ones in

It is not entirely clear why the Milwaukee program is undersubscribed. Some have suggested that it has to do with the lack of space in private schools, the availability of better-funded charter schools, and a preference for public schools that have responded to the competitive threat posed by the voucher program. See Alan J. Borsuk, Charter Schools Gaining on Choice Program, MiLWAUKEE J. SENTINEL, Dec. 22, 2000, at 3B; Scott S. Greenberger, Voucher Lessons Learned, Boston Globe, Feb, 26, 2001, at A1; Jill Leovy, School Voucher Program Teaches Hard Lessons, L.A. TIMES, Oct. 9, 2000, at A1. It may also be due to the fact that the program was only recently expanded to allow for 15,000 vouchers.

185. Henig \& Sugarman, supra note 96 , at 27.

186. See Fla. STAT. ANN. ch. 229.0537 (West, WESTLAW through 2001 1st Reg. Sess.) (describing the "Opportunity Scholarship Program").

187. See Jay P. Greene, Manhattan Inst., An Evaluation of the florida a-Plus ACCOUNTABILITY AND SCHOOL CHOICE PROGRAM (2001) (describing the voucher program in Florida).

188. Private scholarship programs exist in over thirty cities nationwide and involve over 50,000 students. See FuLLER ET AL., supra note 184, at 63-64. It is certainly relevant to note that these private scholarships, like publicly funded voucher programs, target low-income students and offer them some choice of private schools, but no ability to enter good, suburban public schools. See id. It is also likely, as Professor Moe has argued, that the existence of private vouchers helps keep the issue of publicly funded vouchers visible. See MOE, supra note 4 , at 38 . We will not devote much attention to private vouchers, however, because they are really not at the core of the debate over publicly funded vouchers and are unlikely to become so. As Henig and Sugarman describe, most of the private scholarships provide only partial and modest funding for private school tuition, and, more importantly, it "is currently unimaginable that private charity could sustain a nationwide private scholarship scheme that would provide choice opportunities for all the low-income families wishing to pursue them." Henig \& Sugarman, supra note 96, at 28.

189. For a discussion of the failed proposals, see MOE, supra note 4, at 37; Robert C. Bulman \& David L. Kirp, The Shifting Politics of School Choice, in SCHOOL CHOICE AND SOCIAL CONTROVERSY, supra note 96, at 46-52; John J. Miller, Why School Choice Lost, WALL ST. J., Nov. 4, 1993, at A 14; and Mark Walsh, Voucher Initiatives Defeated in Calif, Mich., EDuC. WK., Nov. 15, 2000, at 14.

190. See Amy Stuart Wells, Time To ChoOse 157-58 (1993). 
California, Colorado, Oregon, and Washington. ${ }^{191}$ In each case, voters not only rejected the proposals, but did so by wide margins. ${ }^{192}$ School choice proponents typically blame the losses on teachers' unions and the fact that the unions greatly outspent voucher proponents on initiative campaigns. ${ }^{193}$ Although the formidable opposition of teachers' unions played some role in the defeat of these initiatives, it is hard to accept union opposition as the sole explanation, in part because voucher initiatives have failed even when proponents outspent opponents. Just last year, for example, proponents in Michigan outspent opponents by $\$ 7$ million; yet a voucher proposal that would have given $\$ 3300$ to children in failing schools and allowed other districts to authorize vouchers failed by a wide margin. ${ }^{194}$ Similarly, proponents of the most recent California voucher initiative spent roughly the same amount as did their opponents, but the proposal was nonetheless crushed at the polls by a seventy-one to twenty-nine percent margin. ${ }^{195}$

Voucher ballot initiatives lost in California and elsewhere not only, and perhaps not even primarily, because teachers' unions opposed them, but also because suburbanites did not support them. ${ }^{196}$ As John J. Miller, associate director of the pro-voucher Manhattan Institute, explained after the defeat of the 1993 voucher ballot initiative in California: "School choice failed in California because Republican voters didn't want it." 197 The initiative rejected by California voters would have provided a $\$ 2600$ voucher for use at virtually any private school in the state. Some voucher proponents explained the defeat by pointing to teachers' unions and the biased media, but Miller suggested that the real explanation had more to do with suburban apathy:

Most suburbanites-the folks who make up the GOP's rank and file-are happy with their kids' school systems. Their children already earn good grades, score well on tests, and gain admission into reputable colleges and universities. Moreover, suburban affluence grants a measure of freedom in choosing where to live

191. See Miller, supra note 189. All told, "[v]oters of various states have been asked 10 times to approve either vouchers or tuition tax credits for private school tuition, and they have said no each time." Walsh, supra note 189.

192. See MoE, supra note 4, at 365-69; Miller, supra note 189. California and Michigan voters most recently rejected voucher proposals in November 2000 , and again did so by wide (more than two-to-one) margins. See MOE, supra note 4, at 366-69; Walsh, supra note 189.

193. See, e.g., Robert D. Novak, Halfhearted Fight for Choice, WASH. POST, Oct. 18, 1993, at $A 19$ (blaming the loss of the voucher initiative in California on the lack of funding to match the amount spent by teachers' unions opposed to the initiative).

194. MOE, supra note 4, at 367-68; see also Walsh, supra note 189.

195. MOE, supra note 4, at 366-67; see also Walsh, supra note 189.

196. In this respect, it might be helpful to consider that teachers' unions also strongly opposed Proposition 209 in California, which banned any racial preferences in public education and employment. See Annie Nakao, Prop. 209 Lead Shrinks in Poll, S.F. ExAMINER, Oct. 30, 1996, at Al.

197. Miller, supra note 189. 
and thus provides at least some control over school selection. It's not that suburbanites refuse to admit the country's deep education crisis; they just don't believe the problem affects them personally. ${ }^{198}$

Voucher opponents exploited these sentiments by suggesting, for example, that the voucher program would weaken public schools by taking money away from them and giving it to parents whose children were already attending private schools. ${ }^{199}$ Voucher opponents used similar tactics in fighting the most recent ballot initiatives, in Michigan and California, with similar results. ${ }^{200}$

What Miller and others allude to is an odd disjuncture between the leadership of the two main political parties and their rank-and-file members on the issue of school vouchers. On the one hand, vouchers are typically associated with the Republican Party, and many Republican leaders do support vouchers. ${ }^{201}$ Many suburban members of the party, however, remain skeptical of-if not strongly opposed to-large-scale voucher programs. They do so at least in part out of self-interest: They have already paid a premium in purchasing their homes in order to ensure that their children attend good public schools, and they-like their neighbors-want to protect both the schools and their property values. ${ }^{202} \mathrm{~A}$ wide-ranging voucher program, which allows resident students to exit freely and nonresident students to enter suburban schools, might take money away from local students and local schools and introduce lower-income and minority students. As Bill Burrow, associate director of the first President Bush's Office on Competitiveness, explained, "School choice is popular in the national headquarters of the Republican party but is unpopular among the Republican rank-and-file voters who have moved away from the inner city in part so that their children will not have to attend schools that are racially

198. Id; see also David Barulich, Four Reasons why Voucher Plans Lose Elections, EDUC. WK., Sept. 6, 2000, at 58. Barulich campaigned in favor of the same California initiative and said that his "most difficult encounters were casual conversations in living rooms with white, middle to upper-class conservative voters... who expressed deep reservations about vouchers." Barulich, supra.

199. Miller, supra note 189 . For an insightful and nuanced account of the fight over the California voucher initiative, see MOE, supra note 4, at 359-65. Moe suggests that the money spent by teachers' unions played a role, but so too did the public's ambivalence toward vouchers. He also suggests that the deck is usually stacked against initiatives-that is, it is much easier to defeat an initiative than to secure its passage. See id. On the last point, an instructive counterexample, again, is the passage of Proposition 209 in California, which was obviously able to overcome this status quo bias.

200. See Walsh, supra note 189.

201. See COOKSON, supra note 3, at 17-37; HENIG, supra note 22, at 81-96.

202. Thomas W. Hazlett, Class Warfare: It's Soccer Moms vs. Poor Kids-in a Rout, REASON, Feb. 1997, http://www.reason.com/9702/co.hazlett.html (calling this "the ugly financial story lurking behind the soccer-mom pandering on education"). 
or socioeconomically integrated." ${ }^{203}$ The possibility that school choice might introduce a substantial number of urban students into suburban schools thus makes choice threatening to many suburban parents and homeowners alike. ${ }^{204}$

This chasm within the Republican Party may help explain why, when push comes to shove, leaders in the Republican Party often back away from voucher plans. Governor Wilson, for example, came out in opposition to the 1993 California ballot initiative, just as Republican Governor Engler (as well as Republican Senator Spencer Abraham) opposed the recent voucher initiative in Michigan. ${ }^{205}$ Similarly, Governor Whitman toyed with a modest voucher proposal for New Jersey students, but ultimately let it die in the face of legislative opposition from both Democrats and Republicans. ${ }^{206}$ Most recently, the second President Bush gave up fairly quickly, and without much fight, his initial plan to allow poor students to use federal money to pay for private school tuition. ${ }^{207}$ Surely these Republican leaders were not trying to court the teachers' unions by opposing or dropping their calls for vouchers; more likely, they were responding to the less-thanenthusiastic message being sent by their constituents.

On the other side of the aisle, there is also a gap between the leadership of the Democratic Party and some of that party's core constituents, although the arrows here point in the opposite directions. The leadership of the Democratic Party remains opposed to vouchers for private schools, and this undoubtedly reflects the influence of teachers' unions within the Democratic Party. ${ }^{208}$ African Americans, however, especially those younger than fifty, consistently express strong support for vouchers. ${ }^{209}$ Although this support represents a switch from the 1950s and 1960s, when vouchers were associated with Southern resistance to desegregation, it is not altogether surprising. African Americans are disproportionately represented in failing, urban school systems. ${ }^{210}$ Given that parents are most likely to support

203. COOKSON, supra note 3 , at 68 .

204. Hazlett, supra note 202.

205. On Wilson's position, see Miller, supra note 189. On Engler's and Abraham's opposition, see MOE, supra note 4 , at 367 ; and Walsh, supra note 189.

206. Bulman \& Kirp, supra note 189, at 50-51.

207. See Lizette Alvarez, Senate Rejects Tuition Aid, a Key to Bush Education Plan, N.Y. TIMES, June 13, 2001, at A26.

208. See COOKSON, supra note 3, at 39; Peterson, supra note 4, at 53.

209. Bositis, supra note 4 (reporting the results of four annual surveys, conducted between 1996 and 2000, each of which indicated that "[m]ore African-Americans supported school vouchers than opposed them, and blacks consistently supported them more than whites did"). For similar reports, see MOE, supra note 4, at 212-17; VITERITTI, supra note 23, at 5; and Bulman \& Kirp, supra note 189 , at 38.

210. See Ryan, supra note 20 , at $272-73$. 
vouchers when they are dissatisfied with their children's public schools, the support for vouchers among African Americans is understandable. ${ }^{211}$

With these political and economic dynamics in mind, it becomes easier to understand why the three publicly funded voucher programs operating today look the way they do. The programs in Milwaukee and Cleveland offer vouchers to a limited number of poor students to attend private schools. ${ }^{212}$ The Milwaukee plan explicitly limits the use of vouchers to private schools within city boundaries, thus assuring that Milwaukee voucher students will not enter suburban schools. ${ }^{213}$ The Cleveland plan allows students to use the vouchers at any private school within Cleveland and also at any suburban public school that agrees to accept voucher students; none has. ${ }^{214}$ Florida's plan, which is the most recently adopted and the only ostensibly statewide program, allows students in failing schools to use vouchers at private or public schools. The program pushes students to choose nearby public or private schools, however, as it fails to provide transportation to private schools and explicitly requires parents to transport their children to public schools in other districts, which must accept voucher students only if space is available. ${ }^{215}$

These programs are not designed to provide poor students the opportunity to attend elite private schools. The voucher amounts are fairly modest and enable students to enroll primarily in private, religious schools. Milwaukee's voucher program is the most generous, providing students roughly $\$ 5300$ to use for private school tuition. ${ }^{216}$ The Cleveland program is the least generous, providing a maximum of $\$ 2500$ and requiring parents to pay a portion of private school tuition. ${ }^{217}$ The Florida program provides a maximum of $\$ 4000$ per pupil. ${ }^{218}$ The vouchers represent less than the average amount spent per pupil, either in the Cleveland or Milwaukee districts or in Florida, primarily because the voucher amount is roughly the amount of state aid provided to students and does not include local

211. MOE, supra note 4, at 212-17; Bositis, supra note 4. The failure of most Democratic leaders to respond to African-American support for vouchers may be due not only to the leadership's ties to teachers' unions, but also to the fact that older African Americans tend to oppose vouchers and are more likely to vote than those who are younger. Given that African Americans in general are unlikely to vote for Republicans in any event, Democrats who oppose vouchers may not risk losing many votes. Bositis, supra note 4.

212. See supra notes $184-188$ and accompanying text.

213. WIS. STAT. ANN. $\$ 119.23(2)$ (a) (West 1999) (providing that eligible pupils may use vouchers at "any private school located in the city" of Milwaukee).

214. See OHIO REv. CODE ANN. $\$ \S 3313.974-.979$ (Anderson 1999); Simmons-Harris v. Zelman, 234 F.3d 945, 949 (6th Cir. 2000).

215. See Fla. STAt. ANN. ch. 229.0537 (West, WESTLAW through 2001 1st Reg. Sess.).

216. See Milwaukee Parental Choice Program Facts and Figures for 2001-2002, supra note 184 , at 1 .

217. See ERIK Roush, Cleveland Voucher SySTEM 1 (Legislative Budget Office, Policy Brief, Vol. 1, No. 5, 1999), http://www.lbo.state.oh.us/123ga/publications/periodicals/ policybriefs/cleveland_voucher.pdf.

218. REES, supra note 107 , at 36. 
revenues. ${ }^{219}$ While the voucher amounts have been criticized as being too low, the voucher programs have also been criticized as being too expensive or unfairly funded. In Ohio, for example, the program is more expensive than the voucher amount suggests, because the state continues to allow local districts to count voucher students for purposes of receiving state aid. ${ }^{220}$ And in Wisconsin, where the state has reduced aid to other districts in order to fund the Milwaukee voucher program, districts outside of Milwaukee charge that the funding scheme is unfair. ${ }^{221}$ The funding controversies generated by these programs undoubtedly help explain why the vouchers are fairly modest and are provided only to a limited number of students. ${ }^{222}$ The controversies are also ongoing and threaten the stability of even these limited plans. ${ }^{223}$

Just as these programs are not designed to send voucher students to the local equivalents of Exeter or Andover, it is also obvious that these programs are not meant to open up suburban public schools to inner-city students. This fact is apparent from the structure of the programs, and it is understandable in light of the political forces that shaped the plans. In Milwaukee and Cleveland, for example, minority leaders teamed with state and local Republican leaders to create these programs, which in turn reflect their respective interests. ${ }^{224}$ The minority leaders pushing for the programs

219. Funds for the Cleveland plan are allocated from state aid for disadvantaged pupils, and the voucher amount is substantially less than the average per-pupil amount, which is over $\$ 7000$. RouSH, supra note 217 , at 3 . Half of the Milwaukee plan is funded by a reduction in state aid to the Milwaukee school district, and half by a statewide reduction in aid. See MJLWAUKEE Parental ChoICE Program FACTS AND FIGURES FOR 2001-2002, supra note 184, at 1. The voucher amount is less than the average per-pupil amount, which in 1997-1998 was just shy of $\$ 6500$. Lynn Olson, Fighting Back, EDUC. WK., Jan. 8, 1998, at 268. The Florida plan is funded by transferring state aid from local districts to students who accept the opportunity scholarships, see FLA. STAT. ANN. ch, 229.0537(6)(a)(1), and the amount is less than the statewide average perpupil expenditure, which in 1996 was \$5497, Craig D. Jerald et al., The State of the States, EDUC. WK., Jan. 8, 1998, at 76.

220. See RousH, supra note 217 , at 2-3.

221. See Julie Blair, Fight Erupts over Way Wisconsin Pays for Vouchers, Educ. WK., May 23, 2001, http://www.edweek.org. The financial story in Wisconsin is actually more complicated than this because the state allows local districts that lose money to raise local taxes and then contributes additional state aid when local taxes are increased. As a result, some districts outside of Milwaukee have actually made money as a result of the voucher funding scheme. Id.

222. The Milwaukee program is explicitly limited to no more than fifteen percent of the Milwaukee Public Schools' enrollment, while the Cleveland program is limited by the amount of funds allocated by the legislature. WIS. STAT. ANN. \$ 119.23(2)(b) (West 1999); OHIO. REV. CODE ANN. $\S \S 3313.974-.979$ (Anderson 1999). The Florida program has no set limit on the number of participants; all who attend persistently failing schools are eligible. See FLA. STAT. ANN. chs. 229.0535-.0537. In reality, however, there may be very few schools that qualify as persistently failing, a possibility suggested by the fact that in two years, only two schools have qualified. See supra notes $186-187$ and accompanying text.

223. Legislators in Wisconsin, for example, are considering requiring Milwaukee to foot the bill for the entire voucher program, which would require a $\$ 30$ million tax increase for Milwaukee citizens. See Blair, supra note 221.

224. For the legislative and political history of the Milwaukee program, see COOKSON, supra note 3, at 64-68; VITERITT1, supra note 23, at 98-108; and Jim Carl, Unusual Allies: Elite and 
were interested primarily in improving the educational opportunities available to students in failing schools, and they tended not to be interested in enhancing opportunities for racial integration. ${ }^{225}$ Republican leaders, meanwhile, seized the opportunity to support a market-based educational reform that would operate largely within the confines of urban school districts. ${ }^{226}$ Urban vouchers allow Republican leaders to push a policy that is ideologically attractive and politically low-risk, as it leaves suburbanites alone. If anything, urban vouchers will win the support and votes of suburbanites, because they offer assistance to urban students. ${ }^{227}$ Suburbanites continue to express support for programs that offer greater assistance to inner-city students in failing schools. ${ }^{228}$ At the same time, however, criticizing the bureaucracy of urban school districts as inefficient and corrupt is a popular sport among many legislators and governors, some of whom must believe that doing so plays well in the suburbs. ${ }^{229}$ All of which suggests that a reform that does not provide large sums of money to city-school bureaucrats, but instead allows parents to escape the clutches of those bureaucrats, is likely to be pretty popular among suburbanitesprovided that city kids stay in city schools.

\section{Pulling Together the Politics of Choice}

\section{The Radical Potential of School Choice}

In most areas of the country, school districts or neighborhood schools within large districts are quite segregated by race and income. This is typically a result of the fact that school districts tend to track municipal boundaries and attendance zones within districts track different neighborhoods. Because municipalities, often through exclusionary zoning, are segregated by income (and thus, to a large degree, by race), so too are

Grass-Roots Origins of Parental Choice in Milwaukee, 98 TCHRS. C. REC. 266 (1996). For the history of the Cleveland program, see VITERITTI, supra note 23, at 108-13. In Florida, the Opportunity Scholarship Program was endorsed by a number of African-American state legislators as well as the Urban League of Greater Miami. See Prepared Testimony of the Honorable Jeb Bush to the House Budget Committee, FED. NEWS SERVICE, Sept. 23, 1999, at 3.

225. See VITERITTI, supra note 23, at 98-109; Carl, supra note 224, at 268-75.

226. See VITERITTI, supra note 23, at 109; Carl, supra note 224, at 275-76.

227. Cf. MOE, supra note 4, at 318-19 (noting that more than one-third of those who generally oppose vouchers would be willing to support voucher programs for the inner-city poor, and that these programs are supported $57 \%$ to $35 \%$ among Democrats and $52 \%$ to $42 \%$ among Republicans).

228. See, e.g., Lowell C. Rose \& Alec M. Gallup, The 30th Annual Phi Delta KapparGallup Poll of the Public's Attitudes Toward the Public Schools, PHI DELTA KAPPAN, Sept. 1998, at 41, 49 (reporting that $86 \%$ of those surveyed believe it is "very important" "to improve the nation's inner-city schools," and that $66 \%$ say that they would be willing to pay more taxes to do so).

229. An example of this tendency is found in the increasing number of state takeovers of failing urban school districts. James E. Ryan, The Influence of Race in School Finance Reform, 98 MICH. L. REV. 432, 446-47 \& n.57 (1999). 
the districts that track them. The same is true with regard to neighborhoods within larger districts. ${ }^{230}$ Districts that have higher property values and residents in higher income brackets have a double advantage of being able to spend more locally raised revenues on students who are easier to educate because they come to school with few of the problems that attend students living in poverty. If states and districts adhere to a neighborhood-school policy and allow local districts to raise and spend what they wish on local schools, schools will obviously continue to be segregated by income and race, and they will continue to be funded unequally. ${ }^{231}$

Recognizing these basic facts unveils the radical potential of school choice. Simply put, allowing students to choose freely among schools could transform the way that education is provided in this country. To accept school choice in its most aggressive and purest form is to accept the proposition that all students should be able to choose from a range of schools. Further, if one believes that schools should really compete for students - and compete fairly - then all students should have an equal opportunity to attend all schools. It seems arbitrary to limit choice to a particular type of school, whether public or private, or to schools in a particular geographic area. A robust school choice plan would give all students a ticket good for entry at any school. Under these circumstances, students would have the widest range of choices practicable, and schools would have to compete on the basis of services provided with similar resources. A universal school choice plan thus would undermine the rationales for local control of public schools; local restrictions on attendance would be inconsistent with allowing students to choose freely, and unequal expenditures among localities would be inconsistent with requiring schools to maximize their efficiency by competing fairly with one another.

What we suggest is that, while advocates and commentators rarely discuss the radically equalizing potential of school choice, suburbanites intuitively recognize this potential and the threat it poses to their interests. The typical story about school choice, especially private school choice and to a lesser extent choice among charter schools, suggests that the most important opponents of choice are the teachers' unions. It is certainly true that teachers' unions are formidable opponents of certain kinds of school choice, and that this opposition has shaped and will continue to shape school choice plans. The unions' steadfast opposition to vouchers and their

230. For a more detailed discussion, see Ryan, supra note 20, at 272-84; and Ryan, supra note 229 , at $435-37$.

231. See, e.g., EATON, supra note 130, at 252 ("Because our local communities, especially in the northern metropolitan areas, are still heavily segregated by race and income level, dividing school districts along municipal lines is, for all practical purposes, segregation by race and class."). 
eventual, grudging acceptance of charter schools, for example, certainly helps explain why far more students attend charter schools than receive publicly funded vouchers. ${ }^{232}$ Yet the pattern we have just described suggests that teachers' unions are certainly not the only important characters involved in the school choice drama. If they were that powerful, it would be hard to explain why there are any voucher programs at all. ${ }^{233}$ Moreover, given their strong connection to the Democratic Party, it is hard to point to teachers' unions as the reason why many Republican leaders have opposed or walked away from voucher proposals.

What the pattern instead suggests is that suburbanites are the key players in all school choice plans, public or private. Think first of the fact that suburbanites strongly support local control over student attendance, as demonstrated by their intense resistance to interdistrict desegregation, and that they also strongly support a certain degree of local control over locally raised revenues, as demonstrated by the myriad battles over school finance reform. Then consider that most choice plans, public and private, involve choices within particular school districts, most typically within urban districts. Plans that allow interdistrict choice are not only less prevalent, but they almost always contain restrictions-allowing districts to opt out of participation or to accept transfers only if space is available-designed to protect the autonomy of local school districts. Plans that require suburban schools to accept urban students are extremely rare, almost always the result of court order or settlement and, for that reason, not necessarily stable-as the dismantling of the St. Louis plan demonstrates. Recall as well that charter schools most often, by practice or design, draw students from within the district in which they are located, and that they, too, are located most often in urban areas. Consider, finally, that two of the three voucher plans in existence specifically target poor, urban students and constrain their choices to schools within city limits, while the third allows greater choice in theory but places practical obstacles in the way of those who wish to use their vouchers outside of their home districts.

What do all of these plans have in common? They protect the ability of suburban parents to send their kids to suburban public schools, to spend locally raised revenues primarily if not exclusively on local kids, and to shield their kids from having to attend schools with more than a relative handful of "outsiders." At the same time, the plans represent some attempt to reform urban school systems and improve the opportunities available for

232. See William G. Buss, Teachers, Teachers' Unions, and School Choice, in SCHOOL CHOICE AND SOCIAL CONTROVERSY, supra note 96, at 300, 300-05 (describing the position of teachers' unions regarding charter schools).

233. Teachers' unions opposed the voucher plans ultimately adopted in Cleveland, Milwaukee, and Florida. See VITERITTI, supra note 23, at 98-113; Bulman \& Kirp, supra note 189 , at $47-50$. 
students currently stuck in failing city schools. All of this fits perfectly within a worldview that believes that educational crises exist in the cities but not in the suburbs and that some efforts should be made to address those crises, provided that doing so does not simultaneously threaten suburban school autonomy. This was the worldview essentially expressed by Nixon in his antibusing speech and that has been echoed and implemented time and again by suburbanites faced with the prospect of having to share their schools or their local tax dollars with urban students. ${ }^{234}$ The pattern, in short, is unmistakable. Suburbanites like their public schools, want to be able to devote local money to "their" schools, and want generally to limit attendance to local residents; existing school choice plans, in turn, tend to conform to these preferences.

\section{Suburban Political Power}

If it is clear enough that existing school choice plans reflect suburban preferences, it remains to explain why this is so. The answer, we think, is straightforward: political strength. In most state legislatures, where choice plans are crafted, suburban legislators hold the balance of power. ${ }^{235}$ Although legislators obviously respond to special interest groups on some issues, public choice theory posits and empirical studies confirm that they are more likely to follow the wishes of their constituents on high-visibility issues. ${ }^{236}$ As George Stigler put it, an "obvious characteristic of democratic political life [is that] special minorities...can exploit uninterested

234. See supra Section I.A.

235. See, e.g., Marilyn Gittell, Conclusion: Creating a School Reform Agenda for the Twenty-First Century, in STRATEGIES FOR SCHOOL EQUITY, supra note 6, at 230, 238 ("Suburban interests and power are pervasive in almost all state legislatures and in the state education bureaucracies."); Margaret Weir, Central Cities' Loss of Power in State Politics, CiTYSCAPE, May 1996, at 23, 23 (examining how large cities have fared in state politics and concluding that such politics "are increasingly driven by a suburban-based politics of 'defensive localism' that seeks to limit State action in addressing urban economic and social problems"); see also William Schneider, The Suburban Century Begins, ATLANTIC MONTHLY, July 1992, at 33, 33 (noting that, because of population shifts, "[w]e are now a suburban nation with an urban fringe and a rural fringe" and arguing that national politics is now driven by the concerns of suburban voters).

236. On this aspect of public choice theory, see DanIEl A. FARBER \& PHILIP P. FRICKEY,

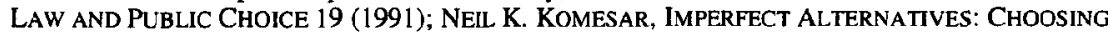
Institutions in Law, EConomics, and Public Policy 53-82 (1994); Arthur T. Denzau \& Michael C. Munger, Legislators and Interest Groups: How Unorganized Interests Get Represented, 80 AM. POL. SCI. REV. 89 (1986); Herbert Hovenkamp, Legislation, Well-Being, and Public Choice, 57 U. CH1. L. REv. 63, 88 (1990); and James Q. Wilson, The Politics of Regulation, in THE POlItICS OF REGULATION 357, $357-72$ (James Q. Wilson ed., 1980). For empirical studies supporting this theory, see, for example, KAY LEHMAN SCHLOZMAN \& JOHN T. TIERNEY, ORGANIZED INTERESTS AND AMERICAN DEMOCRACY 261-388 (1986). For a particularly relevant case study, indicating that legislators in education funding battles tend to follow their constituents' wishes over the wishes of organized interest groups, see Dorothy A. Brown, The Invisibility Factor: The Limits of Public Choice Theory and Public Institutions, 74 WASH. U. L.Q. 179 (1996). 
majorities but will be exploited by interested majorities." 237 Within the realm of state and local politics, few if any issues are more highly visible than those concerning schools and education; electoral majorities, in other words, are keenly interested in education issues. Suburban legislators thus have the political power, as well as the political incentives, to protect their constituents' interests. ${ }^{238}$

At the same time, it is important to recognize that there are not many organized groups pushing in the opposite direction-that is, pushing to expand the opportunities for choice beyond particular districts or to abolish neighborhood schools. Those advocating for school choice-especially private school choice and charter schools - are typically not very interested in enhancing opportunities for racial or socioeconomic integration. ${ }^{239}$ Civil rights groups that remain committed to integration, by contrast, devote more of their energy to blocking private school choice than to seeking ways to use choice to enhance integration. The NAACP, for example, has formed a partnership with People for the American Way for the stated purpose of preserving public education. ${ }^{240}$ The partnership's main activity, however, appears to be fighting against vouchers rather than offering much in the way of new programs generally or new ideas for increasing integration in particular. ${ }^{241}$ Given the strength of suburban voters and legislators, it is hard to imagine that even a strong push toward expanding school choice into the suburbs would be hugely successful. As it stands, however, no one is really even pushing that hard.

Consider the situation in Milwaukee, which captures many of the themes we have highlighted and serves as a good concluding vignette. The story of the Milwaukee voucher program has been told often enough that there is now a conventional narrative, which describes how a liberal, African-American state legislator, Annette "Polly" Williams, teamed up with Republican leaders to launch what essentially amounted to a pilot voucher program. ${ }^{242}$ Initially, the program was limited to 1000 students, who could use the vouchers in nonsectarian private schools within the city limits. ${ }^{243}$ Polly Williams pushed the choice program in part because she was fed up with school desegregation within Milwaukee, which she believed

237. GeorGe J. Stigler, THe Citizen AND THE STATE 162 (1975).

238. See, e.g., David M. Herszenhorn, Rich States, Poor Cities and Mighty Suburbs: In Connecticut and New Jersey, Urban Poverty Confronts Leafy Affluence, N.Y. TIMES, Aug. 19, $2001, \S 1$, at 39 (describing suburban political dominance in New Jersey and Connecticut and the reluctance of suburban legislators to devote resources to urban areas, including urban schools).

239. See supra Subsection I.B.4.

240. See Partners for Public Educ., Every Child Counts, at http://www.everychildcounts.org (last visited Feb. 19, 2002) (describing the partnership).

241. See id. (listing activities).

242. See infra notes $244-247$ and accompanying text.

243. See WELLS, supra note 190, at 160-61. 
was unfair to blacks and educationally ineffective. ${ }^{244}$ Her voucher allies were equally uninterested in desegregation, while those civil rights groups that remained committed to racial integration-the NAACP chief among them-opposed the voucher plan. ${ }^{245}$ Given this political lineup, it is not surprising that the voucher plan that finally emerged offered no means by which city students could attend suburban schools, whether public or private, nor is it that surprising that the conventional account suggests that vouchers were offered as an alternative to a failed attempt to desegregate the schools.

What does not make it into the conventional account of the voucher program, and what makes Milwaukee so interesting and instructive, is that the Milwaukee metropolitan area has operated a voluntary desegregation program for the last twenty-five years. ${ }^{246}$ Known as the Chapter 220 plan, this program allows approximately 5500 Milwaukee students to attend suburban schools that have volunteered to accept the students, while 1300 suburban students attend city magnet schools. ${ }^{247}$ Although state leaders have occasionally proposed ending the program, it has survived and remains fairly popular, at least among Milwaukee residents. ${ }^{248}$ Indeed, while 5000 city students attend suburban schools, another 3800 remain on a waiting list to do so. $^{249}$ Moreover, a legislative audit of the program in 1994 found that minority transfer students performed better on statewide achievement tests than minority students in the Milwaukee city schools, including those students who tried to transfer to suburban schools but were unable. ${ }^{250}$ Those who would support expanding this demonstrably effective program, however, clearly lack sufficient political power, which just as clearly resides with those who support the Milwaukee voucher program. Thus, while the number of city students attending suburban schools has remained steady for the last ten years, ${ }^{251}$ during that same time period the

244. See Bulman \& Kirp, supra note 189, at 48; see also Lynn Olson, Choice Plan's Architect Relishes Her Role as State Legislature's Lone Independent, EDUC. WK., Sept. 12, 1990, http://www.edweek.org (describing Williams's 1987 attempt to create an all-black school district in Milwaukee).

245. See VITERITTI, supra note 23, at 102 (noting that the local chapter of the NAACP opposed the plan).

246. See Michael Stolee, The Milwaukee Desegregation Case, in SEEDS OF CRISIS: PUBLIC SCHOOLING IN MILWAUKEe SinCE 1920, at 229, 256-60 (John L. Rury \& Frank A. Cassell eds., 1993).

247. For an overview of the program as of 1994, see STATE OF WIS. LEGISLATIVE AUDIT BuREaU, AN EVAluation of THE CHAPTER 220 PROGRAM (1994). For more recent figures on participation, see VITERITTI, supra note 23, at 99; and Alan J. Borsuk, Eyes on Milwaukee for School Choice, Mil WAUKEE J. SENTINEL, Aug. 21, 2000, at A1.

248. Joseph A. Ranney, "Absolute Common Ground": The Four Eras of Assimilation in Wisconsin Education Law, 1998 WIS. L. REV. 791,816 n.96.

249. See Olson, supra note 219 , at 269.

250. STATE OF WiS. LEgISLATIVE AUdiT BUREAU, supra note 247, at 4.

251. Telephone Interview with James McIntosh, Chapter 220 Financial Officer, Wisconsin Department of Public Instruction (July 11, 2001). 
state legislature expanded the number of vouchers available to Milwaukee students from 1000 to 15,000 . ${ }^{252}$

The lesson from Milwaukee is not that school integration in general, or urban-suburban integration in particular, is a failure and has lost all support among African Americans. What we take from Milwaukee is that there is continued support for suburban-urban integration programs among African Americans, and at least limited tolerance of such programs among suburban districts. ${ }^{253}$ At the same time, however, there is obviously much stronger political support for school choice that is limited to inner cities. What is true in Milwaukee is obviously true elsewhere. Indeed, the voucher program in Milwaukee is yet another version of the compromise proposed by Nixon in his antibusing speech in 1972: A reform that offers some assistance to urban students but makes sure that they remain in city schools. All of this suggests that the radical potential of school choice, if the trends we have highlighted continue, will be contained, and school choice plans will be limited in scope. The next Part tries to gauge what we can expect from such limited plans.

\section{THE CONSEQUENCES OF CONSTRAINED CHOICES}

If our assessment of the political economy of school choice is correct, and if the political and economic dynamics do not change substantially, we should continue to see school choice plans confined to single districts. Within single districts, we should expect to see mostly limited choice plans that allow some students to attend specialized nonneighborhood schools, either public or private, but that also preserve the traditional neighborhood school. In this Part we try to assess the likely impact of such limited school choice plans along three dimensions: racial and socioeconomic integration, academic achievement, and productive competition among schools. These three are the most important and most discussed criteria for assessing school choice plans. Our analysis relies on data regarding the current demographics of school districts and neighborhoods, studies of the impact of previous and existing choice plans, and economic literature on school competition. We cannot pretend, of course, to predict with precision the impact of limited school choice plans; variations among the thousands of school districts, residential mobility, and the limits of existing research are

252. See Wells, supra note 190, at 160-62.

253. Although initially part of a legal settlement, the program has continued past the deadline, in 1993, for the termination of the settlement. See STATE OF WIS. LEGAL AUDIT BUREAU, supra note 247, at 12; $c f$. EATON, supra note 130, at 12-13 (noting that, despite media reports of growing disenchantment among African Americans with busing in Boston and elsewhere, "the waiting list for METCO continues to grow, even though it buses students much farther than typical desegregation plans"). 
but three factors that counsel caution in trying to predict the future here. Nonetheless, we have enough information to provide a general sense of what we can expect limited choice plans to accomplish.

\section{A. Racial and Socioeconomic Integration}

One of the more controversial questions that looms over choice programs involves their implication for racial and socioeconomic integration. The implications are historically framed in unflattering light. As Betsy Levin, among others, reminds us, in the middle of the twentieth century school choice flourished in the South principally as a mechanism to thwart desegregation efforts. ${ }^{254}$ Prohibiting school choice was thus one step toward desegregating Southern schools. Although school choice policies have been used to integrate rather than segregate schools since the $1970 \mathrm{~s},{ }^{255}$ Levin speculates that school choice would nonetheless unwind decades of school integration efforts, fuel increased socioeconomic stratification, and thereby enhance rather than ameliorate social inequities. ${ }^{256}$

Professor Levin is not alone in her concerns. One recurring argument against school choice plans in general and vouchers in particular is that they lead to greater racial and socioeconomic isolation. ${ }^{257}$ This argument reflects a belief that white and black parents, if given the choice, will opt for schools that are more racially homogeneous than current public schools. The argument also reflects a belief that if more families are empowered to choose among education options, the most well-informed, motivated, and economically well-off families are more likely to avail themselves of school choice. ${ }^{258}$ Indeed, even choice proponents recognize the salience of the "skimming effect" as well as the need for policymakers to address this danger when crafting choice programs. ${ }^{259}$

Advancing dire predictions about the impact of school choice on racial and socioeconomic integration is a powerful rhetorical strategy, but it is crucial to examine the often unstated assumptions that underlie such predictions. Suggestions that school choice will exacerbate racial and socioeconomic isolation often rest on an implicit premise that the nation's public schools are fairly well integrated by race and income. As we explain

254. Betsy Levin, Race and School Choice, in SCHOOL CHOICE AND SOCIAL CONTROVERSY, supra note 96, at 266, 267-68; see also HENIG, supra note 22, at 101-06.

255. Cf. HENIG, supra note 22 , at 110-11 (discussing "controlled choice" plans); KAHLENBERG, supra note 23, at 116-30 (same); VITERITTI, supra note 23, at 58-60 (same).

256. Levin, supra note 254 , at 286.

257. See, e.g., McUsic, supra note 77, at 125-28; Martha Minow, Reforming School Reform, 68 FORDHAM L. REV. 257, 283 (1999).

258. See COOKSON, supra note 3, at 91-93.

259. Terry M. Moe, Private Vouchers, in Private Vouchers 1, 23 (Terry M. Moe ed., 1995); see also MOE, supra note 4, at 10 (stating that "readers should be aware that I am a supporter of vouchers"). 
below, this premise is mostly false. Most children in this country attend schools largely identifiable by race and socioeconomic status. ${ }^{200}$ To make progress on this issue, we believe that assessments of the effects of choice programs must be approached from a comparative perspective. Thus, existing integration levels in public schools must be the starting point in determining the likely net impact of school choice, both public and private.

\section{Residential Patterns and School District Demographics}

School enrollment patterns and residential patterns are tightly linked in this country because the overwhelming majority of public school students attend neighborhood schools. Public schools therefore tend to reflect the neighborhoods in which they are located. And neighborhoods in most metropolitan areas remain remarkably segregated by income and by race.

A common measurement of residential segregation is the dissimilarity index, which captures the degree to which various groups are evenly spaced throughout a particular geographic area. For racial segregation, the index measures the percentage of blacks who would have to move to achieve an even residential pattern-where every neighborhood reflects the composition of the larger geographical area. ${ }^{261}$ The higher the index number, the greater the level of segregation, with a score of zero indicating perfect balance and a score of 100 indicating complete apartheid. Looking at segregation by race, in 1990, the average dissimilarity index was $77.8 \%$ for Northern metropolitan areas and $66.5 \%$ for Southern metropolitan areas. ${ }^{262}$ Racial segregation is down a bit from levels recorded in the $1970 \mathrm{~s},{ }^{263}$ but African Americans remain more segregated than any other racial or ethnic group now or in the history of the United States. ${ }^{264}$ They are also more segregated today than they were in 1940, despite decades of efforts to increase residential integration. ${ }^{265}$

Indeed, one-third of all African Americans live under "hypersegregated" conditions, which essentially means that they live in large, contiguous, racially homogeneous neighborhoods clustered around city centers. African Americans living in such cities as Atlanta, Baltimore, Chicago, Dallas, Detroit, Los Angeles, Milwaukee, and New York are not

260. See VITERITTI, supra note 23, at 49; see also infra Subsection II.A.1.

261. Douglas S. MASSEY \& NANCY A. DENTON, AMERICAN APARTHEID: SEGREGation AND THE MAKING OF THE UNDERCLASS 219 (1993).

262. Id. at 222 tbl.8.1 (1993).

263. While most observers agree that residential segregation lessened between 1970 and 1990, little agreement exists on the precise magnitude. For a discussion of the range of estimates, see David M. Cutler et al., The Rise and Decline of the American Ghetto, 107 J. POL. ECON. 455, 471-72 (1999) (discussing estimates ranging from $7.5 \%$ to $16.7 \%$ ).

264. MASSEY \& DENTON, supra note 261 , at 2.

265. Abraham Bell \& Gideon Parchomovsky, The Integration Game, 100 CoLuM. L. REV. $1965,1980(2000)$. 
likely to encounter any whites in their own neighborhoods, the neighborhoods adjacent to theirs, or the ones adjacent to those. ${ }^{266}$ It is a sad paradox that many blacks living in the nation's largest and most populous urban centers are actually quite isolated. ${ }^{267}$

Although segregation in school or housing patterns is often discussed solely in terms of blacks and whites, attention should also be paid to Hispanics, who make up the fastest growing segment of the public school population. ${ }^{268}$ Hispanics have experienced similar, though less dramatic, residential segregation. In 1990, the dissimilarity index for Hispanics living in the largest 100 metropolitan areas in the United States was $45.1 \% .{ }^{269}$ This figure dropped slightly, to $44.6 \%$, by $2000 .{ }^{270}$ This slight decline, however, masks an increase in segregation among Hispanic immigrants; that is, housing segregation increased for those areas with rapidly increasing Hispanic populations. ${ }^{271}$

Just as residential areas are quite segregated by race and ethnicity, they are also economically segregated. In 1990, the dissimilarity index for poor households in the 100 largest metropolitan areas in the country was $36.1 \%{ }^{272}$ This number was higher than the number in 1970 , indicating an increase in economic segregation. ${ }^{273}$ Economic segregation, moreover, interacts and corresponds with racial segregation. Although half of the poor people in metropolitan areas are white, three-quarters of poor whites live in middle-class neighborhoods. ${ }^{274}$ Neighborhoods of concentrated poverty "are overwhelmingly black ghettos and Hispanic barrios." 275

This leads to our final point about racial, ethnic, and socioeconomic residential segregation. A good deal of residential segregation takes place between municipalities rather than within a particular town or municipality. Residential segregation most visibly tracks boundaries separating cities and their suburbs. ${ }^{276}$ Since the middle of the twentieth century, whites and middle-class blacks have left cities in droves, leaving behind cities

266. MASSEY \& DENTON, supra note 261 , at $74-78$.

267. Id. at 77 .

268. Gary Orfield \& John T. Yun, Civil Rights Project, Harvard Univ., RESEGREGATION IN AMERICAN SCHOOLS (1999), at http://www.harvard.edu/civilrights/ publications/resegregation99/resegregation99.html.

269. Memorandum from David Rusk to Rick Kahlenberg 4 (Aug. 29, 2001) (on file with authors).

270. Id.

271. Id. at 1,4 .

272. ld. at 5 .

273. Id.

274. Id.

275. Id.

276. Indeed, racial segregation between cities and their suburbs has become so pronounced that social scientists no longer find it helpful to measure segregation within cities alone. See MASSEY \& DENTON, supra note 261, at 61 . 
increasingly dominated by poor minorities. ${ }^{277}$ By the end of the 1970 s, the pattern of an urban core dominated by blacks surrounded by a ring of predominantly white suburbs emerged. ${ }^{278}$ That pattern has continued, with large numbers of Hispanics joining poor African Americans in the cities. ${ }^{279}$ One consequence of this demographic shift has been to concentrate poverty in urban neighborhoods. And what is true for urban neighborhoods is true for urban schools.

The numbers tell the story, and the numbers are stark. Most AfricanAmerican and Hispanic students attend urban schools that are predominantly minority. In $1996-1997$, for example, nearly $70 \%$ of African-American and nearly 75\% of Hispanic students attended schools that were between $50 \%$ and $100 \%$ minority ${ }^{280}$ Perhaps even more striking, over one-third of African-American and Hispanic students attended schools that were almost exclusively (over $90 \%$ ) minority. ${ }^{281}$ The overwhelming majority of white students, in turn, attended schools that were predominantly white; indeed, the average white student attended a school that was $81.2 \%$ white. ${ }^{282}$

If we shift our gaze from national statistics and focus on some large, urban districts, the intensity of racial and ethnic segregation becomes clear. As of 1995, all of the students in East St. Louis, Illinois, and Compton, California, were minority. ${ }^{283}$ Close to all-between $93 \%$ and $96 \%$ - of the students in Atlanta, Camden, Hartford, Los Angeles, New Orleans, Oakland, San Antonio, and Washington, D.C., were minority. ${ }^{284}$ In Richmond, Virginia, and Newark, New Jersey, over $90 \%$ of the students were minority. ${ }^{285}$ In Chicago, as of $1996-1997$, just under $90 \%$ of the students were minority, while in Detroit in the same year, close to $95 \%$ of the students were minority. ${ }^{286}$ In New York, meanwhile, nearly $84 \%$ of the over one million public school students are minorities. ${ }^{287}$

277. See, e.g., Sheryll D. Cashin, Middle-Class Black Suburbs and the State of Integration: A Post-Integrationist Vision for Metropolitan America, 86 CORNELL L. REV. 729 (2001) (considering the costs and benefits of black suburbs).

278. See Thomas F. Pettigrew, Racial Change and Social Policy, 441 AnNals AM. ACAD. POL. \& SOC. SCI. 114, 122 (1979) ("This doubled proportion of blacks in central cities is the basic fact underlying the spatial maldistribution of the races; and it is the largest single reason for the vast residential separation of black and white citizens in America today.").

279. See MASSEY \& DENTON, supra note 261, at 67, 77.

280. ORFIELD \& YUN, supra note 268 , tbl.9.

281. Id.

282. Id. tbl.11.

283. Craig D. Jerald \& Bridget K. Curran, By the Numbers: The Urban Picture, EDUC. WK., Jan. 8, 1998, at 56 .

284. Id.

285. Id.

286. ORFIELD \& YUN, supra note 268 , tbl.4.

287. Jerald \& Curran, supra note 283 , at 56. 
Where there is racial and ethnic isolation of minorities, there is also usually concentrated poverty. Generally speaking, the larger the percentage of minority students, the larger the percentage of poor students. We consider a school to be predominantly poor if more than $50 \%$ of the students are eligible for free or reduced-price lunches, which is a common measure of student poverty. ${ }^{288}$ Less than $10 \%$ of schools whose enrollment is between $10 \%$ and $20 \%$ minority are predominantly poor. Exactly half of the schools that are $50 \%$ to $60 \%$ minority are predominantly poor. And nearly $90 \%$ of schools that are $90 \%$ to $100 \%$ minority are predominantly poor. ${ }^{289}$ If we narrow our focus again and look at particular urban districts, the extent of poverty in urban public school districts becomes clear. Over two-thirds of the students in Atlanta, Bridgeport, Camden, Jersey City, Chicago, Los Angeles, New York, New Orleans, Newark, and St. Louis are poor. So too are nearly two-thirds of the students in Oakland, Washington, D.C., Baltimore, Detroit, Kansas City (Missouri), Buffalo, and Dallas. ${ }^{290}$

It bears emphasizing that the racial and economic segregation that exists in America's schools typically occurs between districts rather than within the same district. A recent study of all schools that reported data on poverty and race-slightly over 33,000 schools-revealed that most poor primary school students are clustered in majority-poor districts. ${ }^{291}$ The same is true for both African-American and Hispanic students; most attend schools within majority-minority school districts. ${ }^{292}$ This has very important implications for school choice because it means that even if schools within districts were perfectly integrated, schools within those districts would remain majority poor and majority-minority. In order to reduce significantly the isolation by race, ethnicity, and poverty, integration must occur between rather than within districts. ${ }^{293}$

\section{Gauging the Impact of School Choice}

As the demographic statistics indicate, public schools today are highly segregated by race and income. Urban schools, in particular, principally serve poor, minority students, and most minority students attend urban schools. ${ }^{294}$ If school choice plans are confined to single districts and are

288. See infra note 300 .

289. These figures are reported in ORFIELD \& YUN, supra note 268, tbl.13.

290. The district poverty figures are reported in Jerald \& Curran, supra note 283, at 64-65. See also Table 1, infra Subsection II.A.2.

291. See Duncan Chaplin, Estimating the Impact of Economic Integration of Schools on Racial Integration 2-3, 12-13 tbl.A.1 (Oct. 15, 2001) (unpublished manuscript, on file with authors).

292. See id. at 6; ORFIELD \& YUN, supra note 268, tbls.8-9.

293. Cf. Chaplin, supra note 291 , at 6 (concluding that "most segregation (both racial and economic) is across districts and not within districts").

294. See Ryan, supra note 20 , at $272 \&$ n. 92 . 
implemented primarily in urban districts, the effect of such plans on racial and socioeconomic integration will be marginal. The reason is straightforward: If those in a school district are predominantly minority and poor, moving them around through choice plans to other schools within the district will not have much impact on integration levels.

This is not to deny that there may be some movement, in either direction, at the margins. Much will depend on the structure of the plan and the demographics of particular districts. If choice is confined to public and charter schools, there may be slightly more or slightly less integration in particular schools as students move from one setting to another. But given the demographic starting point, it seems implausible that such school choice plans will significantly modify current levels of integration.

If instead of a choice plan confined to public schools, an urban district launches a voucher program, those who use the vouchers to attend private schools may move from a relatively segregated to a relatively integrated setting. This is because in a number of cities, private schools are more racially and socioeconomically integrated than are the public schools. ${ }^{295}$ Poor, minority students who choose private schools may well find themselves in either a more integrated setting, or one that is equally isolated by race and socioeconomics but consists not of poor minorities, but middleclass whites. Evidence from the Cleveland and Milwaukee voucher programs supports this hypothesis, as reports indicate that voucher students are in more integrated settings than are nonvoucher students who remain in city public schools. ${ }^{296}$

Vouchers for private schools, however, can only do so much to enhance racial and socioeconomic integration. To begin, the politics of vouchers have thus far resulted in fairly limited programs, where a small percentage of public school students receive vouchers for use at private schools. If this trend continues, the impact of a voucher program on integration levels will necessarily be slight. A select few students may find themselves in more integrated settings than the ones they departed, but this will do little to alter

295. See, e.g., Nicole Garnett, The NAACP's Parent Trap, WKLY. STANDARD, Dec. 30, 1996-Jan. 6, 1997, at 16, 17 (reporting that "[m]any of the private and religious schools in innercity Milwaukee are more integrated than their public counterparts, some of which are virtually all black"); Jay Greene, The Racial, Economic, and Religious Context of Parental Choice in Cleveland, Paper Prepared for the Annual Meeting of the Association for Policy Analysis and Management 5-8 (Oct. 8, 1999) (unpublished manuscript, on file with authors) (reporting a similar dynamic in Cleveland). See generally Paul E. Peterson \& Jay P. Greene, Race Relations \& Central City Schools: It's Time for an Experiment with Vouchers, BROOKINGS REV., Spring 1998, at 33,36 (reporting statistics that show that private school students are typically "less racially isolated than their public school peers").

296. See Peterson \& Greene, supra note 295, at 35-36; Joe Williams, Religious Schools See Racial Mix: Study Says Integration Rises in Parochial Schools, MILWAUKfE J. SENTINEL, June 26,2000 , at IB. 
the demographics of public schools or the overall levels of integration in urban districts.

Urban districts' integration levels are unlikely to change in any meaningful way even if the programs are expanded in size, as existing private schools will be unable to accommodate all of the voucher students. This is true not only because there is a limited supply of private schools generally, but also because voucher programs have not been-and likely will not be-sufficiently generous to allow voucher students to attend expensive private schools. The private schools available for voucher students will thus continue to be even more limited than the already limited supply of private schools generally. Although it seems fair to assume that new private schools would develop in response to an expanded voucher program, these schools presumably would be filled primarily with voucher students, which obviously would do little to change a district's overall integration levels.

Again, none of this is to deny that integration levels may increase or decrease slightly in districts with school choice plans. It is instead to suggest that such marginal changes, which garner a great deal of attention in the academic literature on charter schools and vouchers, ${ }^{297}$ should not distract us from the larger picture. Unless the politics change, the larger picture will remain dominated by racial and socioeconomic segregation, with a splash of exceptional, integrated areas here and there. To provide a better glimpse of this picture and a more concrete sense of the likely impact of choice, we have organized data drawn from a representative sample of American public school districts across the country. As is clear from the table below, we endeavored to report demographic data from four different types of school districts-large urban, small urban, suburban, and rural. Within each of those classifications, we provide data on three different school districts from different geographic locations within the United States. 


\section{TABLE 1. RESIDENCE ${ }^{298}$ AND PUBLIC SCHOOL ENROLLMENT ${ }^{299}$ BY RACE AND POVERTY RATE ${ }^{300}$}

\begin{tabular}{|c|c|c|c|c|c|c|c|c|c|}
\hline & $\begin{array}{l}\text { Ress. } \\
\text { White }\end{array}$ & $\begin{array}{c}\text { Res. } \\
\text { Black }\end{array}$ & $\begin{array}{l}\text { Res. } \\
\text { Hisp. }\end{array}$ & $\begin{array}{c}\text { Res. } \\
\text { (other) }\end{array}$ & $\begin{array}{l}\text { Sehool } \\
\text { White }\end{array}$ & $\begin{array}{l}\text { Schnol } \\
\text { Black }\end{array}$ & $\begin{array}{l}\text { School } \\
\text { Hisp. }\end{array}$ & $\begin{array}{l}\text { Schoot } \\
\text { fother) }\end{array}$ & $\begin{array}{l}\text { School } \\
\text { Poverty }\end{array}$ \\
\hline \multicolumn{10}{|l|}{ Urban: } \\
\hline New York City & 39.5 & 28.7 & 24.4 & 7.4 & 15.7 & 35.8 & 37.5 & 11.0 & 69.6 \\
\hline Los Angeles & 35.8 & 14.0 & 39.9 & 10.3 & 10.9 & 13.8 & 68.5 & 6.8 & 73.3 \\
\hline Chicago & 37.3 & 39.1 & 19.6 & 4.0 & 10.3 & 53.7 & 32.6 & 3.4 & $* 70.1$ \\
\hline \multicolumn{10}{|l|}{ Small Urban: } \\
\hline Charl.-Meck. & 64.6 & 31.8 & 1.4 & 2.2 & 50.9 & 41.7 & 2.9 & 4.5 & 38.1 \\
\hline Indianapolis & 75.2 & 22.6 & 1.1 & 1.1 & 38.4 & 58.5 & 2.4 & 0.8 & $* 53.5$ \\
\hline Portland, $O R$ & 82.6 & 7.7 & 3.2 & 6.5 & 66.7 & 16.0 & 6.4 & 10.9 & 38.2 \\
\hline \multicolumn{10}{|l|}{ Suburban: } \\
\hline Plano, TX & 85.4 & 4.0 & 6.2 & 4.3 & 75.5 & 6.1 & 7.6 & 10.8 & 3.5 \\
\hline Bellevue, WA & 85.0 & 2.2 & 2.5 & 10.3 & 70.1 & 3.7 & 6.5 & 19.6 & $" 7.8$ \\
\hline Loudoun Cty., VA & 87.7 & 7.1 & 2.5 & 2.7 & 81.9 & 8.7 & 4.7 & 4.7 & 4.2 \\
\hline \multicolumn{10}{|l|}{ Rural: } \\
\hline Gilbert, AZ & 84.8 & 1.5 & 11.6 & 2.1 & 84.4 & 2.2 & 10.6 & 2.8 & "9.1 \\
\hline Moore, OK & 88.5 & 1.8 & 3.4 & 6.4 & 80.1 & 4.3 & 3.9 & 11.6 & $\bullet 10.3$ \\
\hline St. Johns Cty., FL & 88.3 & 8.7 & 2.3 & 0.8 & 86.2 & 11.0 & 1.7 & 1.1 & $\bullet 15$ \\
\hline
\end{tabular}

298. See Bureau of the Census, U.S. Dep't of Commerce, Statistical abstract of THE UNITED STATES 47-49 tbl.48 (1998) (giving 1990 U.S. census data).

299. See NAT'L CTR. FOR EdUC. STATISTICS, U.S. DEP'T OF EdUC., DigeST OF EDUCATION STATISTICS: 2000, at 116 thl.93 (2001) (presenting fall 1987 enrollment data).

300. Except where otherwise indicated, "school poverty" reflects the percentage of a school district's students eligible for the free or reduced-price lunch program, and the data are drawn from NAT'L CTR. FOR EdUC. STATISTICS, U.S. DEP'T OF EDUC., ChaRACTERISTICS OF THE 100 LARGEST PUblic ElementaRY aNd SECONDARY SCHOOL DISTRICTS IN THE UNITED STATES: 1999-2000, at 28-29 tbl.9 (2001). Data for district figures noted with * are drawn from CouNCIL

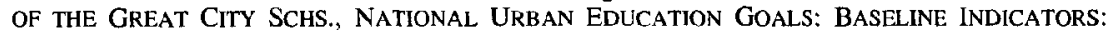
1990-91, at 118-211 (1992). We could not locate reliable school free or reduced-price lunch program eligibility data for all school districts, and those districts are noted with ${ }^{\circ}$. For these districts we report general school poverty rate data for five- to seventeen-year-olds drawn from NAT'L CTR. FOR EDUC. STATISTICS, supra note 299, at 117 tbl.95.

The school poverty rate is typically lower than the percentage of students eligible for free and reduced-price lunch, as students whose families are above the poverty level by a certain amount are still eligible for federal lunch programs. See 42 U.S.C. \& 1758(b)(1)(A) (1994) (providing, inter alia, that students from families below $185 \%$ of the federal poverty level are eligible for reduced-price lunch). The difference in poverty rates between some of the districts is thus slightly exaggerated because of the different data used. Nevertheless, it remains very safe to conclude that there is a stark difference between urban and suburban district student poverty. Finally, as between the two types of data, we feel that free and reduced-price lunch program eligibility is a more probative proxy for student socioeconomic status, especially in the school context. It is also the criteria used to determine federal Title I aid, which is designed to assist "poor" students. See 20 U.S.C. \$§ 6301-6514 (1994). 
The data presented in Table 1 reflect the general trends outlined above and raise several points that warrant discussion. To begin, white enrollment in the nation's largest districts (New York City, Los Angeles, and Chicago) is comparatively minimal, principally because these districts experienced significant losses of white students. Equally important, the percentage of poor students in each of these districts is quite high, nearing or exceeding seventy percent. The high degree of racial and socioeconomic isolation within these districts indicates that intradistrict choice plans there would have little chance of significantly altering levels of integration. To the extent that the relatively few white and nonpoor students are clustered in particular schools, intradistrict choice may improve integration. On the other hand, to the extent those students are evenly distributed, choice could increase segregation. Both movements, though, will be at the margins. No matter how evenly one might disburse students within urban districts, these schools will remain majority-minority and majority poor.

Another notable demographic feature of large urban districts is that the proportion of whites remaining in these large cities exceeds, in many instances by more than $100 \%$, the proportion of white students attending public schools. Thus, not only do white families avail themselves of school choice by departing urban areas when their children reach school age (or never living in cities to begin with), those white families who do live in the nation's largest cities avail themselves of private schools at a rate that greatly exceeds their nonwhite counterparts. White families' mobilityboth in terms of departing urban for suburban areas and departing public for private schools-fuels a disproportionate absence of white schoolchildren in urban public schools and generates levels of racial isolation in urban public schools that exceed what residential integration levels predict. This, again, suggests that choice plans that include vouchers for private schools may increase integration levels by tapping into the white student population in private schools. Conversely, it also suggests that plans limited to choice among public schools in these districts have no real chance-absent significant demographic changes—of altering the drastic degree of racial isolation that currently exists.

If we turn our attention to smaller urban districts, we see a good deal of variation even among just the three sample districts. Some of the variation flows from different demographics within traditionally drawn urban districts. Indianapolis is majority-minority, for example, while Portland is majority white, which will affect the opportunities for increased racial integration through intradistrict choice. Similarly, there are fewer poor students in Portland than in Indianapolis, which would make it easier to achieve socioeconomic integration in Portland because fewer students would have to change schools to achieve this goal. 
Some of the variation among these districts has less to do with the demographics of the cities themselves and more to do with how the district lines are drawn. Many Northern and Western metropolitan areas are divided into a large number of relatively small, independent school districts that usually track city lines. This approach contrasts with a number of metropolitan areas in the South, such as Charlotte-Mecklenburg, that organize school districts along county lines. ${ }^{301}$ County-wide school district attendance zones reduce the possibility for nearby predominantly white public school districts and thereby enhance the prospect for integrated schools. ${ }^{302}$ Because they also include suburban areas, the overall poverty rates in such districts also tend to be lower than in districts that only include central cities.

Choice plans within districts that include cities and suburbs almost always have a greater chance of improving racial and socioeconomic integration than choice plans confined to districts that only include central cities. But the choice must be fairly widespread and must essentially require the abandonment of neighborhood assignments or neighborhood preferences. This may be especially difficult to accomplish in a number of these Southern districts, which are just now being released from desegregation decrees that required busing in order to achieve and maintain integration. (Charlotte-Mecklenburg, for example, was just declared unitary in September 2001.) ${ }^{303}$ Often the drive for unitary status is motivated by a desire within the district to return to neighborhood schools; those neighborhood schools, in turn, because of lingering residential patterns, would be largely segregated by race. ${ }^{304}$ Under those circumstances, the odds that a district released from a busing plan will choose to adopt a choice plan that rejects neighborhood assignments seem fairly slim.

On the other hand, if the drive for unitary status is not a popular one, and if there is political support for continuing integration efforts, transitioning from mandatory busing to controlled choice may actually be easier in these metropolitan districts than elsewhere. In CharlotteMecklenburg, for example, most reports suggest that the desegregation plan was politically popular and that the drive for unitary status was not widely supported. $^{305}$ Charlotte-Mecklenburg thus may be fertile ground for a

301. Gary Orfield, Metropolitan School Desegregation: Impacts on Metropolitan Society, 80 MINN. L. REV. 825, 841 (1996) (emphasizing the importance of the South's county-line school districts on bolstering school integration levels).

302. Id.

303. See Belk v. Charlotte-Mecklenburg Bd. of Educ., 269 F.3d 305 (4th Cir. 2001).

304. In Charlotte-Mecklenburg, for example, residential areas continue to be very segregated by race. See id. at 311 (Traxler, J., concurring). See generally ORFIELD \& YUN, supra note 268 (arguing that the dismantling of desegregation decrees is causing schools, especially in the South, to resegregate).

305. See, e.g., DougLAS, supra note 144, at 215-54; Douglas M. Jarrell \& Scott W. Gaylord, Will 4th Circuit Continue Race-Based Assignments?, NAT'L L.J., Dec. 11, 2000, at B9. 
widespread, intradistrict choice plan that offers an alternative means to maintain racial and socioeconomic integration; indeed, the district has already begun contemplating such a plan. ${ }^{306}$

The sample rural and suburban districts, finally, present a picture that is nearly the perfect opposite of that presented by large, urban districts. The rural and suburban districts are predominantly white and middle-class. The rural schools are between roughly eighty-five and eighty-nine percent white, as are the suburban schools. Poverty rates are higher in the rural than in the suburban schools, but poverty in the rural districts is still far below that of the urban districts. Choice confined to suburban and rural districts, therefore, would not significantly affect racial or socioeconomic integration levels in the schools in these districts, because the students are nearly all white and middle-class. Again, intradistrict choice in these districts could alleviate or exacerbate racial or socioeconomic isolation, depending on the current distribution of students, but the overall impact on integration levels would necessarily be slight.

\section{B. Academic Achievement}

For many involved in the choice debate, the ultimate barometer of success or failure is student academic achievement. We tackle this issue second not because we quarrel with that ranking of priorities, but rather because academic achievement and integration often intertwine. To be sure, exactly what causes some students to perform well and others to perform poorly is endlessly debated in the literature. Amid a vigorous debate, a consensus exists that a student's own socioeconomic status, as well as the socioeconomic status of the student's peers, greatly affect the student's academic achievement and social behavior. ${ }^{307}$ There is also some agreement that good teachers, strong principals, small schools, small class sizes, and parental involvement in schools can improve achievement, but the

306. See SCHOOL CHOICE 2001: WhAT'S HAPPENING IN THE STATES 169-70 (Robert E. Moffit et al. eds., 2001). Districts, of course, may be constitutionally prohibited from explicitly using racial criteria in student assignment, including any school choice plan. The extent to which race can be used in student assignment outside of the remedial context remains an unsettled constitutional question. See Note, supra note 129. The use of socioeconomic status for student assignment is more clearly constitutional, as it would not trigger strict scrutiny. For just this reason, Wake County, North Carolina, recently adopted a socioeconomic integration plan to take the place of its racial integration plan. See KAHLENBERG, supra note 23, at 251-54.

307. James Coleman was the first to report this phenomenon in his famous 1966 study for the Department of Health, Education, and Welfare, which has since become known simply as the Coleman Report. James S. COLEMAN ET AL., U.S. DEP'T OF HEALTH, EDUC. \& WELFARE, EQUALITY OF EDUCATIONAL OPPORTUNITY 301-04 (1966). Scores of subsequent studies have confirmed Coleman's conclusion. For citations to the literature, see KAHLENBERG, supra note 23, at 25-28; and Ryan, supra note 20, at 287 n. 167. 
significance of these variables remains subject to debate. ${ }^{308}$ Added to these specific areas of contest is the more general dispute over the extent to which expenditures correlate with achievement-i.e., over how much money "matters." 309

We do not wish to add fuel to these debates, although we must note that it seems clear that something as complex as academic achievement almost assuredly does not pivot on any single variable, such as funding, teacher quality, or class size. We instead focus on a fact beyond dispute: Schools with a majority of poor students rarely, if ever, perform as well as their middle-class counterparts. This holds true even when substantial resources are provided to these schools. There are several reasons why this is so, as we explain below, but the most important point is the clear and undisputed one that schools of concentrated poverty almost always perform poorly. If school choice plans, as we predict, do little to alter the demographics of schools or to break apart and preclude schools of concentrated poverty, it follows that those plans will likely do little to alter the student achievement levels within those schools. Again, there will likely be some movement in both directions at the margins, but the larger picture will be one of stasis. We begin with evidence regarding the relationship between concentrated poverty and academic achievement, and then turn to emerging data on existing choice programs, which thus far support our hypothesis that limited choice plans will have a limited impact on student achievement.

\section{Concentrated Poverty and Academic Achievement}

High-poverty schools, especially high-poverty urban schools, almost always have lower levels of academic achievement than do low-poverty schools. Studies reaching this conclusion abound. A 1997 longitudinal study of 40,000 students, for example, concluded that " [t]he poverty level of the school (over and above the economic status of an individual student) is negatively related to standardized achievement scores." ${ }^{310}$ This study confirmed that "the poverty level of certain schools places disadvantaged $86-90$.

308. For a further discussion of research on this point, see KAHLENBERG, supra note 23, at

309. For research generally skeptical of a correlation between educational spending and educational achievement, see ERIC A. HANUSHEK ET AL., MAKING SCHOOLS WORK (1994); Allan R. Odden \& Lawrence O. Picus, School Finance 277-81 (2d ed. 2000); and Eríc A. Hanushek, The Impact of Differential Expenditures on School Performance, EDUC. RESEARCHER, May 1989 , at 45 . For research generally supportive of such a correlation, see Ronald F. Ferguson, Paying for Public Education: New Evidence on How and Why Money Matters, 28 HARV. J. ON LEGIS. 465 (1991); and Larry V. Hedges et al., Does Money Matter? A Meta-Analysis of Studies of the Effects of Differential School Inputs on Student Outcomes, EDUC. RESEARCHER, Apr. 1994, at 5 .

310. Michael J. Puma et al., U.S. Dep't of Educ., Prospects: Final Report on STUdENT OUTCOMES 73 (1997). 
children in double jeopardy. School poverty depresses the scores of all students in a school where at least half the students are eligible for subsidized lunch, and seriously depresses the scores when over 75 percent of students live in low-income households." 311 A similar study conducted in 1993 found that students in low-poverty schools typically score fifty to seventy-five percent higher on reading and math tests than do students in high-poverty schools. ${ }^{312}$

In addition to depressing achievement, attending a high-poverty school also depresses academic attainment. Students attending high-poverty schools are more likely to drop out than students attending low-poverty schools. ${ }^{313}$ This helps explain why dropout rates remain alarmingly high in many cities. The average dropout rate in the nation's forty-seven largest school districts is more than twice the national average of $12.1 \%{ }^{314}$ In individual districts, the dropout rates astonish. In 1998, for example, the overall dropout rate in Cleveland was seventy-two percent; in Memphis and Milwaukee, it exceeded fifty-six percent. ${ }^{315}$ Problems also persist for those students who remain in high-poverty, urban schools. Urban teachers report spending more time on classroom order and discipline than their nomurban counterparts, ${ }^{316}$ as well as more problems relating to student absenteeism, ${ }^{317}$ pregnancy, ${ }^{318}$ and weapons possession. ${ }^{319}$ Finally, those who manage to graduate from high-poverty, urban schools are less likely to attend college than those who graduate from low-poverty schools. ${ }^{320}$

There are a number of reasons why high-poverty schools tend to produce such dismal academic records. One of the most important is peer influence. In 1966, James Coleman released a mammoth and controversial report on the nation's schools, which concluded that in determining student achievement, family background matters the most, followed by the

311. Id. at 12 .

312. Michael J. Puma et Al., U.S. DeP'T of EduC., Prospects: The Congressionally MANDATED STUDY OF EDUCATIONAL GROWTH AND OPPORTUNITY-INTERIM REPORT 44 (1993).

313. KAHLENBERG, supra note 23, at 54.

314. See COUNCIL OF THE GREAT CITY SCHS., supra note 300, at xvi (reporting a four-year dropout rate for the nation's largest forty-seven school districts in 1990 of 26.1\%); NAT'L CTR. FOR EDUC. STATISTICS, supra note 299, at 129 tbl.107 (reporting the national dropout rate in 1990 at $12.1 \%$ ).

315. Jay P. Greene, Manhattan Inst, High School Graduation Rates in the UNITED STATES 4 (2001). It must be noted that Greene's definition of "dropout" is fairly expansive and includes some students who are typically left out of dropout calculations, such as students who dropped out but later earned a GED.

316. LaURA LiPPMAN ET al., NAT'L CTR. FOR EDUC. STATISTICS, U.S. DEP'T OF EDUC., URBAN SCHOOLS: THE CHALLENGE OF LOCATION AND POVERTY 116 (1996).

317. Id. at 114 figs.4.41-.42.

318. Id. at 124 figs.4.56-.57.

319. Id. at 120 figs.4.50-.51.

320. KAHLENBERG, supra note 23, at 54 ("Few students graduating from high-poverty high schools are likely to be going on to college: just 15 percent of inner-city graduates do."). 
characteristics of the student body. ${ }^{321}$ What mattered very little, he concluded, was school spending. ${ }^{322}$ Although scores of social scientists continue to debate the influence of spending, ${ }^{323}$ a remarkable consensus has formed on the point that the socioeconomic status of one's peers matters a great deal ${ }^{324}$ Indeed, study after study confirms that the social composition of the student body is more highly related to achievement, independent of the student's own social background, than is any other school factor. ${ }^{325}$ Education commentators of every stripe acknowledge the robustness and consistency of these findings. ${ }^{326}$ Simply put, "[i]f there is one thing that is more related to a child's academic achievement than coming from a poor household, it is going to school with children from other poor households." ${ }^{27}$

The explanation for this effect is both straightforward and intuitive. Students from higher socioeconomic backgrounds, like their parents and teachers, tend to have higher expectations and aspirations regarding academic achievement. In schools, as in other communities, most participants tend to conform to the dominant culture. In schools that are majority middle-class, that culture typically is one that values academic achievement and generally expects students to attend college. This school environment is contagious; it affects most students and thus tends to raise the aspirations and motivation of poorer students. In schools that are majority poor, by contrast, expectations and motivations tend to be fairly depressed. ${ }^{328}$ Indeed, in poor inner-city schools, researchers have found that the dominant school culture often actively denigrates academic success, associating success in school with "acting white." ${ }^{329}$ To be sure, this results not from some moral failing of poor or minority students, but rather from the starkly different realities confronting many of these students. Presented

321. COLEMAN ET AL., supra note 307, at 298-305.

322. See id. at 21-22, 296-97, 312-16.

323. See sources cited supra note 309.

324. See, e.g., Gary ORfield \& Susan E. Eaton, Dismantling Desegregation 53 (1996) (stating that the powerful influence of the socioeconomic status of peers on student achievement is "[o]ne of the most consistent findings in research on education").

325. James S. Coleman, Toward Open Schools, PUB. INT., Fall 1967, at 20 (summarizing the findings of the Coleman Report). For a discussion of the numerous studies confirming this point, see KAHLENBERG, supra note 23, at 26-28.

326. KAHLENBERG, supra note 23, at 37 (" '[M]oney is not the only issue that determines inequality. A more important factor, I am convinced, is the makeup of the student enrollment, who is sitting next to you in class." (quoting Jonathan Kozol)); Chester E. Finn, Jr., Education That Works: Make the Schools Compete, HARV. BuS. REV., Sept.-Oct. 1987, at 63, 64 (acknowledging that "disadvantaged children [tend] to leam more when they attend[] school with middle-class youngsters").

327. Trine Tsouderos, Schools Out of Balance: Murfreesboro Rezoning May Fix Inequalities, TENNESSEAN, Dec. 27, 1998, at 2A (quoting James Guthrie).

328. For a discussion of the numerous studies confirming these observations, see KAHLENBERG, supra note 23, at 48-58.

329. Signithia Fordham \& John U. Ogbu, Black Students' School Success: Coping with the “'Burden of 'Acting White,'” 18 URB. REV. 176, 177 (1986). 
with few positive role models and surrounded by poverty and despair, poorer students have little reason to expect that hard work in school could lead to success afterward, and some poor, minority students may come to define themselves in opposition to white, middle-class culture. ${ }^{330}$

Evidencing the importance of peers are examples and studies that show positive gains from socioeconomic integration and relatively little gains from increased funding in predominantly poor schools. As for the former, the overwhelming weight of the research suggests that one of the most promising ways to improve student academic achievement is to put poorer, struggling students into majority middle-class schools, with students who want to excel academically and whose families support such goals. ${ }^{331} \mathrm{By}$ contrast, there is very little evidence that increased expenditures in predominantly poor schools have thus far improved academic achievement. Milliken II funding, for example, has been of very limited success, even when quite generous. ${ }^{332}$ Similarly, the largest federal compensatory program, Title I, has been notoriously ineffective in generating sustained achievement gains. ${ }^{333}$ In cities that spend "substantially more ... than their surrounding suburbs," moreover, Gary Orfield and Susan Eaton find that

330. The existence of an "oppositional culture" in poor, African-American neighborhoods and schools has received increased academic attention. See, e.g., Philip J. Cook \& Jens Ludwig, The Burden of "Acting White": Do Black Adolescents Disparage Academic Achievement?, in THE BLACK-WHITE TEST SCORE GAP 375, 376-84 (Christopher Jencks \& Meredith Phillips eds., 1998). The theory is that when subordinated minorities, including African Americans, have been defeated in attempts to assimilate, they develop a sense of collective identity in opposition to the majority culture. Thus,

[i]f whites speak Standard American English, succeed in school, work hard at routine jobs, marry, and support their children, then to be "black" requires one to speak Black English, do poorly in school, denigrate conventional employment, shun marriage, and raise children outside of marriage. To do otherwise would be to "act white."

MASSEY \& DENTON, supra note 261 , at 168 . Significantly, although most recent studies focus on African Americans, adherence to an oppositional culture seems to have more to do with class than with race, as studies indicate that poor whites are also more likely than affluent whites to devalue education and denigrate middle-class achievement norms. KAHLENBERG, supra note 23, at 52. Nonetheless, the theory remains, as one would expect, fairly controversial. See, e.g., Richard $\mathbf{H}$. Sander, Book Review, 44 J. LEGAL EDUC. 143, 150 (1994) (reviewing MASSEY \& DeNTON, supra note 261) (challenging the "generalizations" that "fit well into the common media images picturing the deepening failure of inner-city schools").

331. Richard J. Murnanc, Evidence, Analysis, and Unanswered Questions, 51 HARV. EDUC. REv. 483, 486 (1981); see also KAHLENBERG, supra note 23, at 25-29 (describing numerous studies confirming this point); Ryan, supra note 20 , at 287 \& n.167, 297-301 (same). Importantly, the evidence also suggests that the introduction of poorer students into more affluent schools does not depress the achicvement of affluent pupils, provided that the schools remain majority middleclass. KAHLENBERG, supra note 23, at 38-42. Although this may seem too good to be true at first, it makes sense when one recognizes that the majority culture of a school determines the school environment. Id. at 39-42.

332. Ryan, supra note 20, at 289-91.

333. See Gary Natriello \& Edward McDill, Title I: From Funding Mechanism to Educational Program, in HARD WORK FOR GOOD SCHOOLS: FACTS NOT FADS IN TITLE I REFORM 31, 33-34 (Gary Orfield \& Elizabeth H. DeBray eds., 1999) (reviewing research on Title I and concluding that, despite billions of dollars spent and huge increases over time in funding, the program has produced only "small, short-term, achievement effects"). 
performance is still worse when the city schools are segregated by race and socioeconomic status. ${ }^{334}$ Other studies, finally, have found that poor students in middle-class schools achieve higher levels of academic achievement than do poor students in predominantly poor schools, even when the predominantly poor schools spend more per pupil. ${ }^{335}$ As David Rusk, author of one of these studies, concluded, to improve education we should focus less on "moving money" and more on moving families and students. ${ }^{336}$

This is not to suggest that peers are the sole determinant of academic success or that increasing expenditures would necessarily be futile. In addition to peers, teacher quality clearly influences academic achievement, as does the degree of parental involvement in the school..$^{337}$ But just as motivated peers are typically found in more affluent schools, so too are high-quality teachers and active parents. ${ }^{338}$ This combination of variables, more than any single one, creates a nearly insuperable set of interacting obstacles for high-poverty schools, as Richard Kahlenberg forcefully describes:

The portrait of the nation's high-poverty schools is not just a racist or classist stereotype: high-poverty schools are marked by students who have less motivation and are often subject to negative peer influences; parents who are generally less active, exert less clout in school affairs, and garner fewer financial resources for the school;

334. ORFIELD \& EATON, supra note 324 , at 83.

335. See KAHLENBERG, supra note 23 , at 28, 36-37 (discussing studies); Ryan, supra note 20, at 298-300 (same).

336. David Rusk, To Improve Poor Children's Test Scores, Move Poor Families, ABELL REP., June-July 1998, at 1, 5. Rusk found that $61 \%$ of low-income students in Alamo Heights passed the Texas Assessment of Academic Skills, while only 39\% of low-income students in San Antonio passed, even though San Antonio spent more per pupil. In Alamo Heights, however, only $17 \%$ of students were low-income, while San Antonio's student poverty rate was $88 \%$. Id. Benefits from greater socioeconomic integration of students, it should be noted, bear on nonacademic student behavior as well. See Susan E. Mayer, How Much Does a High School's Racial and Socioeconomic Mix Affect Graduation and Teenage Fertility Rates?, in THE URBAN UNDERCLASS 321, 327 (Christopher Jencks \& Paul E. Peterson eds., 1991) (reporting that high school students attending higher socioeconomic schools are less likely to drop out and become pregnant than similar students attending lower socioeconomic schools).

337. On the influence of good teachers on achievement, see MARK KELMAN \& GILLIAN LESTER, JUMPING THE QUEUE 138-45 (1997); Ronald Ferguson, Can Schools Narrow the BlackWhite Test Score Gap?, in THE BLACK-WHITE TEST SCORE GAP, supra note 330, at 318, 365-66; and Adam Gamoran, Resource Allocation and the Effects of Schooling: A Sociological Perspective, in MiCROLEVEL SCHOOL FINANCE 207, 211-13 (David Monk \& Julie Underwood eds., 1988). On the influence of active parents on achievement, see CHUBB \& MOE, supra note 1, at 16; TIMOTHY Z. KEITH ET AL., EFFECTS OF PARENTAL INVOLVEMENT ON EIGHTH GRADE ACHIEVEMENT (1992); Joyce L. Epstein, Parent Involvement: What Research Says to Administrators, 19 EDUC. \& URB. SOC'Y 119 (1987); and Esther Ho Sui-Chu \& J. Douglas Willms, Effects of Parental Involvement on Eighth-Grade Achievement, 69 SoC. EDUC. 126 (1996).

338. For an exhaustive review of the literature on this point, see KAHLENBERG, supra note 23, at 61-76. 
and teachers who tend to be less qualified, to have lower expectations, and to teach a watered-down curriculum..$^{339}$

These factors point to a devastating paradox. Racial and socioeconomic patterns currently interact with public school student assignment policies in a manner that consigns those students most in need of high-quality educational services to educational environments less equipped to deliver them.

The key question is whether school choice will change any of this. Our analysis in the first Part indicates that we should not expect much change. Instead, it suggests that most school choice plans will do little to alter the demographics of schools, and thus will do little to break apart the concentrated poverty that exists in many urban school districts. If choice schools remain similar in socioeconomic status to current public schools, there is little reason to assume that choice alone will improve academic achievement. Concentrated poverty in choice schools, in other words, will be just as daunting an obstacle as it is in existing public schools.

To be sure, there may be some improvement. Choice schools may be smaller than regular public schools, and they may have smaller classes, both of which have been found to correlate with increased achievement. ${ }^{340}$ We might also imagine some greater parental involvement, for example, when parents choose their child's school. It is unlikely that there will be significant increases, however, given that some parents will have no additional time to spend and that some choice schools will be farther from a student's home, making participation more difficult for parents. We could also imagine that some high-quality teachers will be drawn to choice schools, especially if those schools offer teachers more autonomy. ${ }^{341}$ But it seems unrealistic to expect a significant migration of strong teachers to choice schools absent higher pay. It seems equally unrealistic to expect that sufficient resources will be devoted to choice schools to support higher pay for teachers than is currently available in many middle-class, suburban schools. Indeed, school choice is often proposed as an alternative to increasing expenditures in predominantly poor schools, and it often entails providing students less funding rather than more ${ }^{342}$ In short, there is some reason to expect limited academic gains from school choice, but not much more. Research on the limited existing plans buttresses this hypothesis.

339. Id. at 47 .

340. See id. at 89 (discussing research on class size).

341. See Caroline M. Hoxby, Wolld School Choice Change the Teaching PROFESSION? (Nat'l Bureau of Econ. Research, Working Paper No. 7866, 2000), http://www.nber.org/papers/w7866.

342. See supra note 219 and accompanying text. 


\section{Evidence from Existing Choice Plans}

Evidence on the actual or potential benefits of school choice, especially when it involves private schools, has always been controversial. The controversy originated with Professor Coleman, who along with several colleagues published the first major quantitative study exploring differences in achievement between public and private (principally Catholic) school students. Coleman and his colleagues found that students in private schools performed slightly better, after controlling for the students' race and socioeconomic background. ${ }^{343}$ Their findings, not surprisingly given the stakes, attracted sustained criticism. ${ }^{344}$ More recently, for every study finding an advantage for private schools, ${ }^{345}$ another study concludes that little or no such advantage exists. ${ }^{346}$ Indeed, the controversy surrounding the research is becoming so searing that at least one observer worries that the debate itself will blunt the potential influence of high-quality research on the growing policy debate surrounding vouchers. ${ }^{347}$

Despite the swirling controversy, some helpful and relatively uncontroversial conclusions may be drawn. To begin, there is little evidence yet that charter schools significantly improve student achievement. Some of this has to do with the paucity of data: There are few student achievement data sets for charter schools that are amenable to sophisticated and nuanced analyses. What data do exist, moreover, are either inconclusive or contradictory. For example, a 1999 study of Arizona charter schools concludes that "it appears that charter schools are not performing very differently from other regular [Arizona] public schools." 348 That same report also notes, however, that the achievement data "provide[] some indication of student progress in charter schools." ${ }^{349}$ A similar evaluation of Arizona charter schools one year later found more positive results. Researchers from the Goldwater Institute evaluated three years of data (1997-1999) and concluded that "students enrolled in charter schools for

343. James S. COlEMAN ET AL., High SCHOOL ACHIEVEMENT 180 (1982).

344. See, e.g., Arthur S. Goldberger \& Glen G. Cain, The Causal Analysis of Cognitive Outcomes in the Coleman, Hoffer and Kilgore Report, 55 SoC. EDUC, 103 (1982) (criticizing the Coleman study for flaws in sampling, research design, and sample bias).

345. See, e.g., Caroline Minter Hoxby, The Effects of Private School Vouchers on Schools and Students, in HOLDING SCHOOLS ACCOUNTABLE 177 (Helen F. Ladd ed., 1996).

346. See, e.g., Adam Gamoran, Student Achievement in Public Magnet, Public Comprehensive, and Private City High Schools, 18 EDUC. EVAlUaTION \& POL'Y ANALYSIS 1 (1996).

347. Jeffrey R. Henig, School Choice Outcomes, in SCHOOL CHOICE AND SOCIAL CONTROVERSY, supra note 96 , at 68,98 .

348. Lori A. Mulholland, Arizona Charter School Progress Evaluation 39 (1999), at http://www.ade.state.az.us/charterschools/info/CharterSchoolStatusMainReport3-1599.pdf.

349. Id. (emphasis added) 
two and three consecutive years have an advantage over students staying in TPSs [traditional public schools] for the same period of time." 350

None of these reports, however, claims that charter schools have yet succeeded in significantly boosting achievement. This may be due in part to the fact that many charter schools are fairly new. It is nonetheless consistent with earlier research demonstrating the importance of the socioeconomic status of schools. Charter schools tend to reflect the status of the districts in which they are located. It would be surprising, therefore, if these schools consistently posted significantly stronger academic results.

There is more positive news regarding student achievement in voucher programs, but the scholarly debate on this question often generates more heat than light. Studies of the publicly funded Milwaukee voucher program illustrate the scholarly controversy. ${ }^{351}$ On the one hand, a study by the stateappointed program evaluator found no systematic differences between voucher students in Milwaukee's private schools and their counterparts in Milwaukee's public schools. ${ }^{352}$ However, reanalyses of the same data by other researchers uncovered systematic differences. ${ }^{353}$ In a third independent analysis of the Milwaukee data, Professor Rouse found a modest systemic advantage for private schools in mathematics achievement and no such advantage in reading scores ${ }^{354}$ In his survey of the empirical research on the influence of educational vouchers on student academic achievement, Professor Levin, no advocate of vouchers, ${ }^{355}$ concurred in "Rouse's careful analysis." ${ }^{356}$ Similar controversy has surrounded studies of privately funded voucher programs, with one team of researchers

350. Lewis Solmon et al., Does Charter School Attendance Improve Test Scores?: The Arizona Results 4 (Mar. 2001) (unpublished manuscript, on file with authors).

351. It should be noted that while academic disputes concerning such technical issues as sample bias, control groups, and regression equations are usually confined to academic journals, such disputes surrounding the Milwaukee voucher program have managed to spill into the national press. See, e.g., Bob Davis, Class Warfare: Dueling Professors Have Milwaukee Dazed over School Vouchers, WALL ST. J., Oct. 11, 1996, at A1.

352. John F. Witte et al., Fifth-Year Report: Milwaukee Parental Choice Program (1995), http://dpls.dacc.wisc.edu/choice/choice_rep95.html; JOHN F. WITTE, THE MARKET APPROACH TO EDUCATION 125, 133-43 (2000) (arguing that voucher students in private schools in Milwaukee have not improved in math or reading).

353. See Jay P. Greene et al., Effectiveness of School Cholce: The Milwaukee EXPERIMENT (Program in Educ. Pol'y \& Governance, Harvard Univ., Occasional Paper 97-1, 1997), http://www.ksg.harvard.edu/pepg/other/mil.htm; Paul E. Peterson, School Choice: A Report Card, 6 VA. J. SOC. POL'Y \& L. 47, 70-71 (1998) (arguing that voucher students in private schools in Milwaukee have improved their achievement in their third and fourth years).

354. Cecilia Elena Rouse, Private School Vouchers and Student Achievement, 113 Q.J. ECON. 552 (1998).

355. Professor Levin acknowledges that educational vouchers can generate positive individual gains, but he concludes that these are offset by the negative social consequences. See Henry M. Levin, Educational Vouchers: Effectiveness, Choice, and Costs, 17 J. POL'Y ANALYSIS \& MGMT. 373, 374 (1998).

356. Id. at 378 . 
reporting positive findings and the next team criticizing the other's methodology. ${ }^{357}$

Despite the lingering disputes, some fairly clear findings are beginning to emerge. As Jay Greene observes, in the last few years there have been seven random-assignment ${ }^{358}$ and three non-random-assignment studies of school choice experiments from eight different programs, conducted by several different researchers. ${ }^{359}$ Although they disagree on the magnitude, the authors of all ten voucher studies find at least some academic benefits to students enrolled in the voucher programs. ${ }^{360}$ It is surely possible that one or even a few of the studies might be flawed, but the probability that all ten studies might be wrong is very low.

Consistent findings of academic benefits associated with voucher programs that place students in private schools comport with the research regarding the importance of socioeconomic integration. Many private schools-including urban Catholic schools-are more integrated economically (and racially) than public schools. ${ }^{361}$ To the extent poorer students are using their vouchers to enter higher socioeconomic status schools, existing research would predict that their academic performance would improve. However, if and when space runs out in existing private schools and poor voucher students end up in newly created, predominantly poor private schools, we should expect the academic benefits associated with private school vouchers to wane.

That the benefits from private school voucher programs would likely wane as capacity is reached does not mean that choice plans could never result in overall academic gains in the absence of significant socioeconomic integration. It just means that the gains will likely be fairly limited. The example of Catholic schools, which is more nuanced than generally portrayed, is again helpful. High-poverty Catholic schools generally outperform high-poverty public schools, which suggests that changing the school environment rather than altering the student body can produce some

357. Compare William G. Howell et al., Test-Score Effects of School Vouchers in Dayton, Ohio, New York City, and Washington, D.C.: Evidence from Randomized Field Trials, Paper Presented at the Annual Meeting of the American Political Science Association (Sept. 2000) (unpublished manuscript, on file with authors) (finding positive academic gains), with Kate Zernike, Doubt Is Cast on Blacks' Gains Under School Voucher Program, SAN DIEGO UNIONTRIB., Sept. 15, 2000, at A8 (reporting methodological criticisms of the study).

358. Professor Hoxby has described random-assignment as the "gold-standard" of research designs. See CARoline M. HoXby, Cambridge SCH. Choice Conference, EfFects of VOUCHERS ON STUdENTS AND FAMILIES 72, 85 (Manhattan Inst., Conference Series No. 5, 2000) (describing the desired methodological characteristics of empirical choice research); see also Jay P. Greene, The Surprising Consensus on School Choice, PUB. INT., Summer 2001, at 19, 19.

359. Greene, supra note 358 , at 26.

360. $I d$.

361. See ANTHONY S. BRYK ET AL., CATHOLIC SChOOLS AND THE COMMON GOOD 73 (1993); Peterson \& Greene, supra note 295, at 36. 
academic gains. ${ }^{362}$ At the same time, however, high-poverty Catholic schools do not perform as well as their more affluent counterparts, nor do inner-city Catholic schools serving high concentrations of low-income children perform as well as more socioeconomically integrated suburban public schools. ${ }^{363}$ This is just what the research regarding the importance of socioeconomic integration would suggest, and it is perfectly consistent with our hypothesis that choice plans that are limited in scope are unlikely to produce more than limited academic gains.

\section{School Choice and School Competition}

There are two basic questions regarding the relationship between school choice and school competition. The first is whether increased competition among schools generates improvements in education, and the second is whether school choice plans will foster much competition. The first question has received a good deal of attention, and the emerging evidence suggests, as we explain, that there are indeed gains from competition. The second question has not received as much attention, but it is probably the more important one given the political constraints we identify in this Article. And here the evidence supports what common sense would suggest: The more limited the plan, the more limited the competition. To the extent competition is limited, the gains from competition will also be limited.

School choice advocates rarely dwell on the connection between socioeconomic status and academic achievement. ${ }^{364}$ Instead, they tend to place a great deal of faith in the power of competition to improve schools generally and to boost academic achievement in particular. The precise causal link between increased competition and academic gains is rarely specified, however, and the theoretical connection between competition and overall educational gains is rarely explained. In theory, it is not entirely clear why competition through school choice would inevitably produce overall gains. ${ }^{365}$ It may be that choice results in advantaged parents and students clustering in particular schools, which would benefit those schools but do nothing for, or harm, less advantaged schools. (Consider here the inequalities among colleges and universities.) Put differently, the same selfsorting that might increase family-level utility might simultaneously decrease net social utility by reducing the socially optimal level of

362. See KAHLENBERG, supra note 23 , at 101.

363. See BRYK ET AL., supra note 361, at 264-66.

364. Kahlenberg is an important exception. See KAHLENBERG, supra note 23, at 47-76.

365. Caroline Minter HoXby, Does Competition Among Public SChOOls Benefit STUDENTS AND TAXPAYERS? 4-5 (Nat'l Bureau of Econ. Research, Working Paper No. 4979, 1994), http://papers.nber.org/papers/w4979. 
socioeconomic integration. Local residents, in addition, might have less reason to care about local school quality because residence would no longer determine school placement, and housing values and local school quality would no longer be as tightly linked. Any competitive gains through choice might thus be offset by losses from a reduction in monitoring by local residents. ${ }^{366}$

Notwithstanding the theoretical uncertainty, emerging empirical evidence suggests that existing competition has increased overall academic gains, although the evidence supports only tentative conclusions and is disputed. ${ }^{367}$ The best work on this topic has been done by Professor Caroline Hoxby. In a widely cited paper assessing competitive effects generated by public schools, Professor Hoxby found positive effects on student achievement, further noting that these effects are more pronounced in districts with less-educated adults and in districts located in states with higher degrees of local control. ${ }^{368}$ Additional findings suggest that competition can increase high school graduation rates, ${ }^{369}$ lead to greater resources being directed to the classroom, ${ }^{370}$ and increase overall school performance. ${ }^{371}$

If we assume, as seems quite plausible, that there are positive benefits to competition, the question that remains for school choice programs is whether they will spur much productive competition. The evidence suggests, as one would expect, that limited choice plans produce limited competitive effects. ${ }^{372}$ Consider, for example, the evidence from Arizona. Because of the number of charter schools there, Arizona provides something approaching a natural experiment for assessing their competitive

366. See Cecilia Elena Rouse \& Michele McLaughlin, Can the Invisible Hand Improve Education?: A Review of Competition and School Efficiency 8 (Feb. 1998) (unpublished manuscript, on file with authors) (suggesting that school choice "may decrease the monitoring incentive of residents living near 'good' schools since property values would no longer be as dependent on the quality of the neighborhood schools"); cf. FISCHEL, supra note 5, al 4-13 (showing that homeowners monitor government policies that affect their property values). To the extent school choice breaks the link between the quality of local schools and property values, it could also reduce incentives to support generous funding of schools by nonparent homeowners. See McUsic, supra note 77 , at 121.

367. Compare, e.g., GREENE, supra note 187 (finding positive competitive effects in Florida). with Gregory Camilli \& Katrina Bulkley, Critique of "An Evaluation of the Florida A-Plus Accountability and School Choice Program," 9 EDUC. POL'Y ANALYSIS ARCHIVES (2001), at $h t t p: / / e p a a . a s u . e d u / e p a a / v 9 n 7$ (challenging Greene's findings on the Florida program).

368. See HOXBY, supra note 365; see also Rouse \& McLaughlin, supra note 366, at 40.

369. See Thomas S. Dee, Competition and the Quality of Public Schools, 17 ECON. EDUC. REV, 419 (1998).

370. See CARoline M. HoXby, Do Private Schools Provide Competition for Public SchOOLs? 28-29 (Nat'l Bureau of Econ. Research, Working Paper No. 4978, 1994), http://www.nber.org/papers/w4978; Thomas S. Dee, Expense Preference and Student Achievement in School Districts 21 (May 1998) (unpublished manuscript, on file with authors).

371. See GREENE, supra note 187 , at ii.

372. See generally Frederick M. Hess, The Work Ahead, EDUC. NEXT, Winter 2001, at 8 (discussing the likely effects of a range of stimuli on public school performance). 
effects on other public schools. By. 1998, Arizona's charter school legislation had spawned 222 charter schools that served approximately 20,000 students, which represented $2.3 \%$ of Arizona's total school-age population. ${ }^{373}$ Due to the development of charter schools, some Arizona public school districts lost more than ten percent of their student enrollment. $^{374}$

Through teacher surveys focused on changes in school policy or practice implemented at the leadership level between 1994 and 1997, researchers sought to assess school-district-level changes attributable to the emergence of competition from charter schools. They observed some competitive effects and noted that many education scholars would find these effects to be "beneficial." ${ }^{375}$ However, they characterized the size of the effects as "modest" and noted the presence of a "ceiling [e]ffect." 376 That is, public school districts do not appear to respond to competitive pressures generated by charter schools beyond a "certain level." ${ }^{377}$ This, of course, makes perfect intuitive sense: The more limited the competition, the more limited the response.

Because most school choice plans, especially those involving vouchers, are currently quite limited, the threat to existing schools is small. Indeed, given that enrollments and spending have generally increased over the last ten years, losing some students through choice plans may not constitute much of a threat at all. ${ }^{378}$ To be sure, publicity surrounding school choice, especially publicly and privately funded voucher programs, might spur some response from public school officials who wish to avoid the embarrassment of students and parents lining up to apply for vouchers and clamoring to exit the public schools. But if the amount of exit from schools is capped at a low amount, few tangible consequences will follow for public schools that lose a few students. This will be true not only for voucher plans, but also for any school choice plan that offers a limited number of students an exit option. As with integration and achievement, then, it seems safe to conclude that limited choice plans will have limited effects on competition and in consequence limited capacity to force public schools to improve.

In sum, both proponents and opponents of choice policies - especially charter schools and voucher programs - can point to empirical evidence supporting their positions. Our sense is that the research points in a direction favoring choice policies, though we concede that reasonable

373. Frederick Hess et al., Coping with Competition: How School Systems Respond to School Choice 10 (n.d.) (unpublished manuscript, on file with authors).

374. Id.

375. Id. at 28 .

376. Id. at $25-26$.

377. Id. at 26

378. See Hess, supra note 372 , at 8-11. 
people may differ in their interpretations of the admittedly limited and scant data. In addition; we also believe that any optimism about existing choice programs must yield to the constraints we identify and discuss in this Article. Simply put, even if current choice programs succeed in terms of enhancing integration, student achievement, and productive competition, further success is capped by the very structure of the choice programs. More specifically, the ability of suburbs to insulate their public schools from the ambit of choice programs will effectively foreclose choice programs from achieving the full benefits promised by theory. Given suburbs' political and economic incentives, we currently see only limited room for improvement-unless, of course, there exist ways to alter those political and economic incentives.

\section{EXPANDING SCHOOL CHOICE}

If our analysis above is correct, one obvious strategy to improve the effectiveness of school choice would be to expand school choice programs, especially in ways that will increase opportunities for socioeconomic integration. Given the strong relationship between student achievement and the socioeconomic status of a student's peers, choice plans that increase socioeconomic integration are quite likely to increase student achievement as well. And given the strong correlation between race and poverty, choice plans that increase socioeconomic integration are also likely to increase racial integration. ${ }^{379}$ Expanding school choice programs, finally, would increase the competition faced by public schools, which might induce many of those schools to innovate and improve.

This is not to suggest that simply expanding school choice will lead to improvement along all three axes we consider. Depending on how it is structured, an expanded school choice program could lead to increased racial and socioeconomic stratification. If all students in a state, for example, received a voucher for use at private schools, and private schools could in turn charge tuition that was higher than the voucher amount, it is quite easy to imagine that the program would increase economic stratification among schools. ${ }^{380}$ Similarly, simply expanding any and all types of school choice will not necessarily lead to productive competition and improvements in public schools. As suggested above, some competition might boost overall achievement and improve schools, but

379. For a review of the social science evidence on this point, see supra notes $272-275$ and accompanying text. See also Ryan, supra note 20, at 284-307.

380. See, e.g., Liebman, supra notc 2, at 284 (raising this objection to vouchers); McUsic, supra note 77 , at $125-28$ (same). 
other forms of competition might simply exacerbate existing inequalities among schools. ${ }^{381}$

Despite the complexities and uncertainty, it seems reasonably clear that, at least from the perspective of those trapped in failing schools, expanding opportunities for school choice is worth the risk. Students in such schools, almost by definition, do not have much to lose. ${ }^{382}$ Moreover, the main alternative to expanding choice-increasing funding in order to reduce class size, hiring better teachers, and addressing the special needs of poorer students-does not seem obviously more promising. In addition to the political hurdles facing proposals to increase funding for failing schools, especially urban ones, ${ }^{383}$ the efficacy of increased funding remains debatable, as we described above. Even where increased funding does eventually lead to improvements in academic achievement, funding alone does not address racial or socioeconomic isolation, ${ }^{384}$ nor does it do much on its own to increase the efficiency of public schools. Under these circumstances, it seems worthwhile at least to experiment with expanded choice programs that can increase socioeconomic and racial integration, especially given the apparently strong support among the parents of students currently stuck in failing schools. Attention to the details of programs will be crucial, to be sure, but the fact that choice programs can be structured in ways that either help or harm the neediest students hardly seems like a good reason to shy away from experimenting with choice. ${ }^{385}$

The risk calculus for those already attending good schools, as we have explained, is much different. Students in adequate or excellent schools might indeed gain under a choice program, as they and their parents become able to find schools more suited to their needs, interests, or values. On the other hand, students in good public and private schools might lose at least some of their competitive advantage over students in poor schools if choice programs are expanded. It is also possible that expanded choice programs could lead to a decline in the quality of education or overall student achievement at some existing schools, if choice results in decreased funding or a substantial increase in students with special needs. Just as

381. See supra Section II.C.

382. For statistics describing the state of urban schools, see, for example, Ryan, supra note 20 , at 272-75. For a starting anecdotal account of several urban school systems, see JONATHAN KOZOL, SAVAGE INEQUALITIES: CHILDREN IN AMERICA'S SCHOOLS (1991).

383. See Ryan, supra note 229 , at 480 (summarizing the findings of a study suggesting that urban minority districts fare poorly in school finance litigation and reform).

384. For more discussion of this point, see Ryan, supra note 20, at 286-95.

385. There is an interesting parallel here to school desegregation. Decried as a failure by opponents (just as school choice is), social science evidence suggests more accurately that sometimes desegregation is successful in raising achievement and improving race relations, sometimes it is not, and sometimes it makes things worse. Much depends, as intuition would suggest, on how the desegregation plan is structured. Brief of Amicus Curiae NAACP, DeKalb County, Georgia, at 6a-7a, Freeman v. Pitts, 503 U.S. 467 (1992) (No. 89-1290). The same is true for school choice plans. 
importantly, it seems likely that, regardless of the actual consequences of expanded school choice, many suburban parents will perceive it as threatening. Many parents of students in good suburban schools already exercised a form of school choice when they chose their places of residence, and many are quite content with the status quo. Even if expanding school choice would in fact benefit (or at least not harm) their children, suburban parents are likely to be risk averse and wary of any proposals that affect either the student population or the funding of suburban schools.

The central question remaining thus comes into fairly sharp relief: Are there politically acceptable ways to expand school choice in order to increase and improve the opportunities for students in failing public schools? Put more bluntly: Are there plausible ways to increase the opportunities for poor students to attend middle-class public or private schools? Our answer is "yes, but...." In the short run, advocates can pursue a number of promising strategies, some with proven track records, to expand school choice in politically acceptable ways. These strategies include replicating and strengthening some existing choice programs, such as the controlled choice program in Cambridge, Boston's METCO program, and Milwaukee's Chapter 220 program, ${ }^{386}$ as well as devising politically feasible incentives for suburban districts to accept urban students and suburban parents to choose urban schools. The precise strategy or strategies to employ will depend on local circumstances; there is no single strategy suitable for all locales.

But: It is important to recognize that although opportunities to expand choice exist, they are at present fairly limited. Unless political coalitions or preferences change, suburban parents will likely tolerate only a limited number of urban students in suburban schools, while only a limited number of suburban parents will choose urban schools. ${ }^{387}$ For this reason, we believe that advocates interested in expanding opportunities for school choice should also consider ways to alter the current political landscape. One promising long-term approach, which we discuss at the end of this Part, is to bolster access to preschools and to use the experience that parents have in selecting preschools to loosen their reflexive attachment to neighborhood elementary and secondary schools.

386. For descriptions of these plans, see supra Subsections I.B.1-2.

387. Cf. Edward A. Zelinksy, Metropolitanism, Progressivism, and Race, 98 CoLUM. L. REV, 665, 667-68 (1998) (book review) (suggesting that policies to increase residential segregation will succeed only when "the preferences of the American people" support more integration). 


\section{A. Working Within Existing Political Constraints}

There is a tendency in academic writings to offer a new, universal solution to an identified problem. We think this tendency must be resisted here. It surely would be elegant if we could offer a single solution to the problem of how to expand school choice in productive and equitable ways. However, the diversity of school districts and residential patterns renders a universal solution all but impossible. In addition, although proposing new solutions may seem more creative, it would be a mistake, we think, to jettison all existing programs in favor of a novel plan. Instead, those interested in expanding choice should look first to the possibility of replicating and strengthening some existing choice programs. An additional strategy entails devising politically feasible incentives for expanding choice. We discuss each approach in turn, emphasizing, again, that local circumstances will dictate which approach or combination of approaches is most appropriate.

\section{Replicating and Strengthening Existing Programs}

Each of the four types of school choice plans-intradistrict, interdistrict, charter school, and voucher-can generate opportunities for poorer students to escape predominantly poor schools, depending on the demographics of particular districts or metropolitan areas. Each can also offer greater opportunities for racial integration. For school districts that are economically and racially diverse, but in which there is a good deal of residential segregation, expanding opportunities for intradistrict choice is obviously a promising strategy. This could be accomplished by increasing the number of magnet schools, allowing for transfers among different schools within the district, or adopting the sort of "controlled choice" plan created in Cambridge and implemented in a handful of other cities, including Montclair, New Jersey, and Buffalo, New York. ${ }^{388}$

Controlled choice would obviously create the most opportunities for choice, as it would eliminate neighborhood assignments and convert all schools into choice schools; it would also avoid some of the inequities created by magnet schools, which serve a limited number of students and often drain off an inordinate amount of resources from a district's budget. ${ }^{389}$ It is unclear, however, how many districts would be amenable to controlled choice; that some districts have adopted such plans indicates that controlled choice is not out of the question, but the paucity of the plans also suggests

388. For further discussion of controlled choice plans, see supra Subsection I.B.2.

389. See KAHLENBERG, supra note 23, at 128-30 (comparing the benefits of controlled choice to the benefits of magnet schools). 
that they are politically difficult to implement. For those interested in creating controlled choice plans or in encouraging their proliferation, the first step would be to study the political dynamics in places like Cambridge, Montclair, and Buffalo in an effort to learn how to create-if possible-a political climate conducive to such plans. ${ }^{390}$

In metropolitan areas where districts, rather than neighborhoods, are segregated by income and race, interdistrict choice will accomplish more than intradistrict choice. Enhancing opportunities for interdistrict choice will not be easy, and it is not likely that suburban schools in the near future will accept a very large number of urban transfer students. But there are examples of successful, if limited, programs that allow urban students to attend suburban schools. Boston's METCO program, Hartford's Project Concern, and Milwaukee's Chapter 220 program all allow a limited number of urban students to attend suburban schools. ${ }^{391}$ The keys to their success, which could be replicated in other metropolitan areas, seem to be allowing suburban schools to limit the number of transfer students admitted and providing generous funding to schools that accept transfers. Both steps reduce the actual and perceived sacrifice demanded of suburban districts by limiting the burden on those districts, which in turn obviously limits the scope of the programs. Nonetheless, advocates interested in expanding interdistrict choice should pursue efforts to create programs modeled on the METCO program and others similar to it.

Choice advocates should also consider combining such programs with the creation of additional interdistrict magnet schools in urban areas, so that the flow of students goes in both directions. Magnet schools do create some problems of equity, which might be exacerbated if the schools not only draw resources away from other schools within the district, but also do so to educate kids from wealthier suburban districts. ${ }^{392}$ However, to the extent magnet schools succeed in improving the academic achievement of some district students and in attracting parents and students from the suburbs, they may serve as examples of how schools could be structured and financed in ways that improve achievement and racial and socioeconomic integration. Again, given the state of many urban school districts, some additional investments in magnet schools seem worth the risk.

390. For a study of the Cambridge plan, see NORMA TAN, THE CAMBRIDGE CONTROLLED Choice Program (1990). For Montclair, see Beatriz C. Clewell \& Myra F. Joy, Choice IN MontClair, NEw Jersey (1990). For Buffalo, see Christine H. Rossell, The Buffalo Controlled Choice Plan, 22 URB. EDUC. 328 (1987). For a general study of controlled choice, see CHARLES V. Willie \& Michael J. Alves, Controlled Choice: A New ApProach to SChOOL DESEGREGATED EDUCATION AND SCHOOL IMPROVEMENT (1996).

391. See supra Subsection I.B.2 for a discussion of these plans.

392. See KAHLENBERG, supra note 23 , at $128-30$ (describing the "new forms of unfairness" created by magnet schools). 
On a broader scale, efforts should be made to strengthen existing open enrollment plans and to create open enrollment plans in the roughly thirty states where none exists. ${ }^{393}$ To increase the effectiveness of such plans, several steps should be taken. We list them in increasing order of difficulty. First, information about the programs should be made more available to parents, so that they are aware of their choices and can receive assistance in making the best choices for their children. Second, greater transportation assistance should be provided. Depending on the distances involved, as well as the availability of public transportation, offering free transportation could be fairly expensive. It is thus overly facile to suggest simply that states provide free transportation for any and all interdistrict transfers. As it stands, however, few state plans even address transportation issues; at the very least, states should devote attention and some resources to enhancing opportunities for choice by providing some transportation assistance. ${ }^{394}$ Finally, efforts should be made to include more districts in the plan, both as sending and receiving districts. This is the most important and the most difficult improvement that could be made, and there is no single strategy guaranteed to succeed. Requiring all districts to participate is one possibility, but it will not be politically plausible in some states, and it will not always be effective if districts can exclude students simply by saying that they lack space. A more promising approach, which we discuss in more detail below, would be to create incentives for districts to open their schools to incoming transfers.

Similar steps could be taken to replicate, expand, and strengthen existing charter school programs, and advocates should look to existing examples of "strong" charter laws for guidance as well as political leverage ${ }^{395}$ The precise steps necessary to increase opportunities for racial and socioeconomic integration will depend on the demographics of the district or region in which charter schools are contemplated. In districts that are diverse racially and economically but marked by residential segregation, simply expanding the number of charter schools would be a useful first step. One way to do this would be to press states to allow not just districts to approve charters but to provide the same authority to state agencies and state-delegated entities such as universities. States that do not limit granting authority to local districts have a larger number of charter schools, which is not surprising given the incentives of local districts to quash charter applications. ${ }^{396}$ Advocates should also seek more equitable funding of charter schools to ensure that they have a fair chance of competing with

393. For descriptions of existing open enrollment plans, see REES, supra note 107.

394. For similar suggestions regarding information and transportation, see JOHN E. COONS \& Stephen D. Sugarman, Making School Choice Work for All Families 66-69, 87 (1999).

395. For descriptions of existing charter programs, see supra Subsection I.B.3.

396. See id. 
existing public schools and providing a good education. Again, advocates can look to existing examples of states that fund charter schools at levels comparable to traditional public schools. They can also encourage states to take advantage of the funding made available by the federal government for the creation and maintenance of charter schools. ${ }^{397}$

In states or regions where districts are segregated by race and income, advocates should seek to increase the opportunities for students to cross district boundaries to attend charter schools. To begin, advocates could attempt to ensure that there are a decent number of charter schools that are open to nonresident students. One way to do this, which several states have already implemented ${ }^{398}$ is to require that charter schools authorized by state agencies be open to all students within the state on an equal basis. ${ }^{399}$ Another method, also implemented by several states, ${ }^{400}$ would be to allow several districts to cosponsor charter schools. Given existing politics, this may not result in a large number of regional charter schools that span urban-suburban boundaries, but it at least creates the option. Once options for interdistrict charter schools exist, advocates should focus on the same sorts of details that need attention in any interdistrict choice program. They should ensure that parents are sufficiently informed of their options, and they should work to ensure that some provision is made for transporting students.

As for vouchers, finally, two types of programs currently exist: The programs in Cleveland and Milwaukee provide vouchers to poor students in urban districts, and the program in Florida provides vouchers to students in persistently failing public schools. ${ }^{401}$ These existing programs offer vouchers to relatively few students and provide those students little more than the opportunity to attend a private school within the students' residential district. Even these limited programs offer the few students lucky enough to receive vouchers access to a better school. In urban districts where a sufficient number of private schools have space available and are willing to accept voucher students, even restricted voucher programs can move some students from failing, racially and economically

397. Since 1994 , the federal government has offered grants (totaling $\$ 600$ million) to states to support the creation of charter schools through the Public Charter Schools Program. Charter Friends Nat'l Network, Update on Federal Charter School Legislation (Feb. 25, 2002), at http:/www.charterfriends.org/federal-legislation.html. In 2000, Congress approved an additional $\$ 25$ million for grants designed to help finance charter facilities. Id:; see also Improving America's Schools Act of 1994, Pub. L. No. 103-382, sec. 101, pt. C, 108 Stat. 3518, 3824-30, repealed by No Child Left Behind Act of 2001, Pub. L. No. 107-110, sec. 101 1(5)(A), 115 Stat. $1425,1986$.

398. See supra Subsection I.B.3.

399. Advocates might also try to encourage the federal government to give a preference in its funding grants to open enrollment charter schools. See infra Subsection III.A.2.

400. See supra Subsection I.B.3.

401. See supra Subsection I.B.4. 
isolated schools into more academically productive and integrated environments. Simply replicating such programs, therefore, would benefit at least some students. ${ }^{402}$ And replicating these limited programs in other states and cities certainly seems possible; it seems implausible that vouchers are politically acceptable only in Milwaukee, Cleveland, and Florida. ${ }^{403}$

While programs modeled on those existing in Milwaukee, Cleveland, and Florida would help some students, many more would be left unassisted. The harder questions facing voucher advocates are whether the voucher programs can increase in size and whether the opportunities available to voucher students can be expanded. The crushing defeats of state-wide voucher initiatives suggest that we should not expect to see a universal voucher program any time soon, but the steady growth of vouchers in Milwaukee simultaneously suggests that over time, voucher programs can expand. ${ }^{404}$ Starting small may be necessary for political and financial reasons, but as Milwaukee shows, programs need not remain small over time. If voucher programs remain popular and show signs of success, the

402. As voucher opponents often point out, this will do little for those who remain behind in failing public schools and indeed could make a bleak situation even worse as motivated students and parents exit the system. See McUsic, supra note 77 , at 127-28. But this is true of any noncomprehensive choice or integration scheme, including those public school choice programs often favored by opponents of vouchers, such as METCO, which-just like a limited voucher program-allow a few students to escape failing urban schools. Critics of choice plans that are not universal can always point to those left behind, and this is indeed a difficult and delicate question. The real question, though, is a relative one, and it seems far from clear that the second-best solution to a universal choice plan is a universal system of involuntary assignment based on residence, especially when those with the means will always have the option of choosing their place of residence (and thus their children's public school) or choosing a private school. Cf. Charles L. GlenN et al., Parent information for school Choice: The Case of MASSACHUSETTS 18 (1993) ("An inevitable cost of freedom is to experience any remaining constraint as galling. So long as children are simply assigned to schools involuntarily on the basis of where they live, of course, the issue of disappointment does not arise...."). Another alternative, which has been proposed by some commentators, is mandatory socioeconomic integration within and across district lines. See McUsic, supra note 77, at 131-34. If successful, this might be the most productive policy, but this alternative seems politically implausible, for the reasons we discuss in detail in Part $I$.

403. Just as those interested in replicating controlled choice programs would do well to study the political dynanics that led to the creation of such programs, those interested in voucher programs would do well to study the dynamics in Cleveland (and the Ohio legislature), Milwaukee (and the Wisconsin legislature), and the Florida legislature. For an overview of the political dynamics of vouchers, as well as discussion of the political alliance that led to the Milwaukee voucher program, see Bulman \& Kirp, supra note 189, at 47-52. See also HuBERT MORKEN \& JO RENÉE FORMICOLA, THE POLITICS OF SCHOOL CHOICE (1999) (containing a somewhat disjointed discussion of the players involved and strategies employed in school choice initiatives, including those in Cleveland and Milwaukee). In addition, the dynamics that gave rise to the growing popularity of privately funded voucher programs cast additional-if indirect-light upon the relevant political dynamics. For a general discussion, see PRIVATE VouchERS, supra note 259.

404. For a discussion of the state initiatives, see supra Subsection I.B.4. For a description of Milwaukee's voucher plan, see MOE, supra note 4, at 37-38. 
number of vouchers available obviously should increase, although it is impossible to predict just how much growth we can expect.

As for expanding the catalogue of schools at which vouchers can be used, one obvious strategy would be to remove geographical restrictions and allow vouchers to be used at any public or private school. Expanding voucher programs to include all private schools seems a realistic prospect, given that private schools are uniformly afforded the option as to whether they wish to participate at all in accepting voucher students. ${ }^{405}$ Expanding choice to include out-of-district public schools is trickier and raises the same political questions facing those who wish to expand interdistrict public school choice programs. The same options for expansion, as well as the accompanying obstacles, exist here. All schools might be required to accept voucher students, a plausible possibility in light of existing interdistrict choice programs that require all districts to accept transfer students. But such a requirement would be politically impossible in some states and might prove ineffective if schools can thwart potential transfers by claiming to have no space available. An alternative would be to encourage suburban schools to agree to accept a limited number of voucher students, along the lines of programs like METCO in Boston and Project Concern in Hartford. A third option would be to create incentives for suburban schools to accept voucher students, a topic to which we turn momentarily.

For now, it is worth pausing to acknowledge that none of the strategies identified will, on its own, significantly expand school choice. Each step suggested is a relatively small one. Although small steps taken together might actually open up choice to a fairly large number of students, the political constraints we have identified will still work to limit choice programs. As a consequence, questions of fairness regarding those "left behind" will continue to hang over efforts to expand choice. For example, it is questionable whether expanding choice in the ways we suggest would generate sufficient competition among schools that we could be confident that those who cannot or do not choose a school nonetheless benefit from the existence of choice. In addition, it is worth considering the possibility that attention and resources devoted to school choice will divert attention and resources that otherwise would have been directed at the entire population of students in failing school systems. At this point we can only identify these issues; we cannot offer a way to resolve them, in part because

405. At the same time, it must be noted that both the Cleveland and Milwaukee programs limit the use of vouchers to private schools located within their respective school districts. It is unclear what explains this limitation. If it is political opposition, which we simply have not been able to document, then even allowing all private schools to participate may be more controversial than we envision. If the limitations stem instead from practical considerations, such as the difficulty of providing transportation, including private schools may be politically feasible but ensuring access to distant schools may not be. 
it is simply too difficult to predict all of the medium- and long-term consequences of choice for existing public schools. Given the sorry state of many urban school systems and the dim prospects (not to mention glacial pace) of system-wide reform, we think that offering immediate help to even a portion of students in failing schools warrants taking some risks. It is obvious that others may reasonably view the potential costs and benefits differently, but we remain convinced that it is worth thinking of ways to provide meaningful choice to as many students in failing school systems as is politically possible.

\section{Creating Incentives for Expanding Choice}

In addition to replicating existing programs, advocates for expanding choice might consider employing various incentives to make choice more attractive to more potential participants. Incentives could be targeted in at least one of three ways: (1) to make good schools or school systems more willing to accept transfer students; (2) to encourage middle-class children to attend urban schools; and (3) to encourage the creation of charter or private schools that accept students without regard to place of residence. Imagining possible incentives is not difficult. In fact, as we discuss below, commentators have already proposed a number of potential incentives, and some choice plans already rely on incentives to encourage the exercise or acceptance of choice. The hard part is thinking of effective incentives that are politically feasible.

Begin with incentives to encourage good schools or school systems to accept voucher students. A number of liberal proponents of school choice have suggested giving poor students a voucher, for use at public or private schools, valuable enough to make the recipients financially attractive to schools. ${ }^{406} \mathrm{It}$ is certainly plausible that if a voucher is worth a lot of money, good public and private schools would be willing-perhaps even eager if the voucher is really valuable - to accept voucher students. But there is an obvious dilemma here that is often ignored by commentators who advocate

406. Proposals of this sort have been around for quite some time, having been offered in the late 1960s and early 1970s by the likes of Christopher Jencks, Theodore Sizer, and Henry Levinall left-leaning proponents of school choice, at least at the time. See Judith Areen \& Christopher Jencks, Education Vouchers: A Proposal for Diversity and Choice, in EDUCATIONAL VOUCHERS 49, 53-54 (George R. La Noue ed., 1972); Christopher Jencks, Is the Public School Obsolete?, PUB. INT., Winter 1966, at 18; Henry M. Levin, The Failure of the Public Schools and the Free Market Remedy, 2 URB. REV. 32, 35-36 (1968); Theodore R. Sizer, The Case for a Free Market, SATURDAY REV., Jan. 11, 1969, at 34. Contemporary commentators have proposed similar incentives. See, e.g., CoOKSON, supra note 3, at 131-37 (describing an ambitious proposal that would entail giving all children shares in an educational trust fund in reverse proportion to their families' income--i.e., the poorer the family, the greater the value of the share). 
this approach: ${ }^{407}$ It will be very difficult politically to make vouchers worth enough to make voucher students politically and financially acceptable to good schools.

Consider a suburban public school whose per-pupil expenditure is at or above the statewide average. Now imagine that the voucher is to be used by a poor student from an urban district. For the strictly self-interested suburban district, the voucher amount not only will have to ensure that the district does not lose money, but also will have to ensure that the district is compensated for the extra costs associated with educating poorer students. ${ }^{408}$ This would mean that the state would have to fund a voucher that is worth more than the amount spent per pupil within the district. Exactly how much more is anyone's guess, but even if the compensation amount is relatively small, a voucher worth about the average expenditure per pupil in suburban districts would still require a fairly large increase in state funding that was devoted initially to poor students and ultimately to suburban districts or private schools. It is hard to imagine the political forces that could combine to achieve this result. Suburban districts are not typically desperate for money and are generally wary of accepting transfer students, so it is hard to imagine them taking the lead on this issue. Urban districts, in turn, would likely lose money under this scheme and therefore should not be expected to champion it.

This is not to say that providing additional compensation to schools that accept poorer students, either through a voucher program or through a public interdistrict program, is impossible or futile. Some form of bonus payment could be used to help motivate schools to accept students. That money could come from state governments and perhaps also from the federal government, which already provides funding ostensibly for poor students in the form of Title I grants. ${ }^{409}$ Our point is simply that it is

407. For a proposal that, despite its normative appeal, is especially fanciful, see Cookson, supra note 3, at 131-37. Cookson proposes not only that poorer students receive more money for education than wealthier students, but that this system be funded by equalizing school finance schemes and requiring the federal government to contribute fifteen percent of the necessary funds (which would represent nearly a doubling of current federal expenditures on education). Id.

408. Many of those poorer students will also be racial minorities. To the extent that racism affects the calculus of suburban school officials and suburban parents, the compensation payment either will have to be even higher or may simply be unable to overcome resistance. We are not suggesting, of course, that race will play a role in every case in every suburb, but it would blink reality to suggest that race will never be an issue.

409. More than half of the states have some type of "compensatory" program that is designed to channel additional funds to poor students or poor districts, but wealthier students on average still receive more funding (through state and local sources) than do poorer students. See U.S. GEN. ACCOUNTING OfFICE, SCHOOL FinANCE: STATE and FEDERAL EFForTs TO TARGET POOR STUDENTS 6-7 (1998). Title I is supposed to devote resources to poor students and schools with concentrated poverty, although the funding is much more widely dispersed than this initial purpose would suggest. See 20 U.S.C. $\$$ \$ 6301-6514 (1994); see also KAHLENBERG, supra note 23, at 160 (noting that "Title I appears to survive largely because its preferential philosophy has in practice been undercut, so that 90 percent of districts actually benefit"). One way to use this 
unrealistic to think that a bonus payment scheme alone would be dispositive. Additional money might help, but it would be difficult to raise for large numbers of students, and it likely will not be enough to erase the reluctance of good school systems to open their doors to poorer students. Proof of this point exists in Milwaukee and St. Louis: Generous payments have failed to induce suburban districts in Milwaukee to open their schools to more than a relative handful of city students, while similarly generous funding failed to prevent the dismantling of the interdistrict program in St. Louis. ${ }^{410}$

Another way to encourage movement between suburban and urban districts is to encourage middle-class suburban students to attend urban schools. The traditional incentive used to prod such movement is the creation of magnet schools in urban districts that are open to suburban and urban students alike. Magnet schools have been able to attract some suburban students into urban school systems, and they offer urban students the opportunity for a more socioeconomically integrated environment, as well as a more academically challenging one. But the number of suburban students who choose urban magnet schools is usually relatively small, and the number of urban students who can attend them is also quite small. ${ }^{411}$ Although fairly popular, interdistrict magnet schools often provoke some controversy because they entail the redistribution of resources away from urban students to suburban ones. As a result, while we would encourage the creation of additional magnet schools, one has to acknowledge that magnet schools likely will never be more than one small way to expand school choice. $^{412}$

In addition to interdistrict magnet schools, some commentators suggest that intradistrict choice plans might encourage middle-class parents to remain in or move to cities, which would increase socioeconomic integration in urban schools by increasing the supply of middle-class students. ${ }^{413}$ It is certainly conceivable that robust intradistrict choice plans in urban districts could act as an incentive to encourage potential

funding as a form of compensatory payment would be to allow Title I money to follow poor students to whatever school they attend, which is not currently permitted under the law. See Chester E. Finn, Jr., Fixing Schools Without a Voucher Fight, N.Y. TIMES, Jan. 13, 2001, at Al3. The political difficulty, of course, is that this change would probably require reducing the number of schools that receive Title I funds to ensure that the money is devoted only to poor students.

410. For a discussion of the Milwaukee interdistrict program, see STATE OF WIS. LEGISLATIVE AUDIT BUREAU, supra note 247, at 21-23. For a discussion of the St. Louis plan, see WELLS \& CRAIN, supra note 130.

411. See KAHLENBERG, supra note 23, at 129-30 (citing statistics).

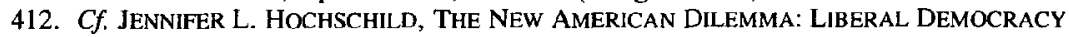
AND SCHOOL DESEGREGATION 72 (1984) (suggesting that "[m]agnets are better characterized as a drop in a bucket than a cure for what ails us").

413. See, e.g., Thomas Nechbya \& Michael Heise, School Finance Reform: Introducing the Choice Factor, in CITY SCHOOLS: LESSONS FROM NEW YORK 367, 376-81 (Diane Ravitch \& Joseph P. Viteritti eds., 2000). 
suburbanites to reside in cities. Those parents, however, would have to be reasonably assured that their children could choose a good school. For this to happen, private schools would likely have to be included in the mix, as most urban districts are not going to have a sufficient supply of good public schools to guarantee to the parents inclined to move to the suburbs that their children will be able to choose a high-quality school if they remain in a city. For the same reason, vouchers would have to be available to every student in the district and not limited to poor students or those attending persistently failing schools. At the moment, the prospects of providing every student in an urban district a voucher seem quite dim, as the experience in both Milwaukee and Cleveland indicates. ${ }^{414}$ Thus, while a robust intradistrict choice plan could be an effective incentive for attracting middle-class parents into poorer, urban districts, a robust plan at the moment seems unrealistic for most districts. Although more limited choice plans-for example, plans that involve only public and charter schoolsmight lead some middle-class parents to remain in urban school systems, it seems unrealistic to expect them to have a significant impact.

A final target for incentives is charter or private schools that would accept students without regard to residence. One way to encourage the creation of charter schools that do not have geographical limitations on admissions is to provide more money to such schools, and specifically to provide additional money for transportation. The federal government, which already provides money to states for the creation and maintenance of charter schools, ${ }^{415}$ could play an important role here. That is, it might be politically feasible to channel additional federal resources to charter schools that draw students from more than one neighborhood or district, which might encourage the creation of such schools in the first place and might help new and existing schools cover transportation costs.

As for private schools, commentators have offered a number of ideas as to how private schools might be encouraged to admit an economically, geographically, or racially diverse group of students. Most proposals either would give poorer students additional funding, which we have already discussed, or would require private schools that accept voucher students to hold open a number of seats for poorer students. Private schools, for example, might be allowed to charge whatever they like for tuition, but if they accept voucher students, they would have to accept a certain percentage of students who could not pay any tuition beyond the voucher amount. ${ }^{416}$ The latter proposals are intriguing and would probably work if

414. See supra Subsection I.B.4.

415. See supra note 397.

416. For an especially thoughtful proposal along these lines, see COONS \& SUGARMAN, supra note 394, at 78-79. Coons and Sugarman, once the leading academic proponents of school finance equalization, see JOHN E. COONS fT AL., PRIVATE Wealth AND PUblic Education 
vouchers were universally available. If vouchers are not universally available, however, and are given only to poor kids, there can be no tit-fortat, where private schools get to accept some voucher students and charge them additional tuition in exchange for accepting some poor kids. Where a limited number of vouchers are given only to poor students and the voucher amount is fairly modest, the question facing private schools will simply be whether they wish to accept some poor students who have a modest voucher to spend. Some religious and secular schools that do not charge much tuition will do so, as they already have, but many private schools will likely decline to participate.

In sum, existing choice programs can be replicated and strengthened, and incentives can be used to encourage the expansion of school choice. Taken together, all of these efforts might add up to fairly substantial increases in the availability and scope of school choice. But until suburban parents come to see school choice as a potential benefit rather than a threat, increasing school choice in meaningful ways will remain difficult. There will be less overall support for choice, as many suburbanites will continue to believe that it is unnecessary and potentially threatening to their schools and residential property values, and there will be resistance to opening up the suburbs for those seeking to exercise choice. The final issue to discuss, then, is whether there is any hope that the politics we have described might change such that suburbanites become more supportive of choice.

\section{B. Working To Alter the Politics of Choice}

There are at least two related ways that the politics of school choice might be altered. One method would be to encourage the formation of larger, more organized, and more unified coalitions in support of school choice. The school choice "movement" at present is quite fragmented and unorganized. ${ }^{417}$ The groups and advocates involved tend to push for certain types of school choice and to resist or refuse to support other types. The most important divide is between public and private school choice programs. ${ }^{418}$ Some groups, like the NAACP and teachers' unions, support

(1970), have since become champions of targeted voucher programs designed to help disadvantaged students. See, e.g., COONS \& SUGARMAN, supra note 23.

417. See CHUBB \& MOE, supra note 1, at 207 ("To the extent the movement for choice can be called a movement at all, it is an extremely fragmented and conceptually shallow one. It lacks mission."); MORKEN \& FORMICOLA, supra note 403, at 286 ("[T]here is no unity among the existing educational reform groups as to what the best kind of school choice is. The result is that there is a fragmentation among the organizations as to what is the most practical type of school choice to support financially or politically.").

418. See, e.g., HENIG, supra note 22, at 215 ("Some advocates of public school choice invest the line separating public and private schools with almost mystical significance. Crossing that line is taboo, because once it is crossed, it will be impossible to stem the flow of vital life forces from the public sector."); see also CHUBB \& MOE, supra note 1, at 219-26 (proposing a school choice 
public school choice but adamantly oppose private school choice. ${ }^{419}$ Other groups, such as the Institute for Justice, appear most interested in private school choice, while providing some support for charter schools..$^{420}$

In theory, if the various groups that support school choice could form a unified coalition in favor of choice, the chance of expanding school choice programs would improve. One could imagine, again in theory, the NAACP and the Institute for Justice agreeing to support both public and private school choice, provided that both types of choice offer substantial opportunities for poorer students to attend predominantly middle-class schools. If an ideologically broad but unified coalition were to form, this might not only increase interest-group pressure for choice; it might also help galvanize public support for choice. Together, this could motivate state legislatures to act. If school choice interest groups remain fragmented, by contrast, it seems unlikely that legislatures will be motivated to adopt any school choice plan that is likely to upset suburban voters.

It is unclear, of course, if even a unified coalition in favor of school choice would be successful in moving legislatures to adopt choice programs that interfere with the current prerogatives of suburban schools. Perhaps an even larger obstacle, however, inheres in the groups themselves. Put bluntly, it does not seem likely that these groups would be willing to work together and to compromise their positions in order to present a unified front. Although both the NAACP and the Institute for Justice, for example, represent minority parents and students, it seems close to fanciful to suggest that they might work together to support a mutually acceptable choice plan. Given the different philosophies of these groups, the possibility of their putting aside their differences in order to work together for school choice seems remote. What is true for the NAACP and the Institute for Justice seems true for other groups as well. It is hard to imagine, for example, teachers' unions agreeing to work together with groups that support private school choice.

If altering the politics of choice through the creation of new coalitions seems unlikely, perhaps the preferences of suburbanites themselves could be altered. That is, perhaps it is possible to convince some suburban parents that school choice, both public and private, is something from which they could benefit, which in turn would increase support for more expansive school choice plans. This is obviously not a small task, nor is it one that can be accomplished overnight. But there currently exists an intriguing

plan that would give parents a voucher for tuition and would convert all public schools into tuition schools).

419. See supra Section I.C.

420. See Inst. for Justice, Legal Cases, at http://www.instituteforjustice.org/cases/index.html (last visited Apr. 19, 2002) (describing cases in which the Institute for Justice is involved). 
opportunity to make progress along this front. That opportunity can be found in state and federally funded preschool programs.

The provision and organization of preschool education differs dramatically from the provision and organization of elementary and secondary education. The majority of preschools ${ }^{421}$ are privately run, and many parents pay tuition on their own for preschools. ${ }^{422}$ A substantial and growing minority of children, however, participate in state or federally funded programs. The oldest and most well known of these is the federal Head Start program, which provides funds to local agencies to support preschools for children living in poverty. As of 1998, there were 822,000 children in Head Start schools. ${ }^{423}$ In addition, the federal Individuals with Disabilities Education Act supports preschool programs for children with disabilities, and in 1998 served 572,000 children. ${ }^{424}$ Title I, finally, also provides federal funds for high-poverty school districts, which can be used to support preschool programs. As of 1996-1997, there were over 260,000 students in Title I prekindergarten programs. ${ }^{425}$

At the state level, government-funded programs now exist in forty-one states and the District of Columbia. ${ }^{426}$ Most of this growth has occurred in the last twenty years, and the growth continues to accelerate. In 1991-1992, for example, 290,000 children participated in state prekindergarten programs. ${ }^{427}$ As of $1998-1999$, that figure had more than doubled, to $725,000 .^{428}$ Despite this explosive growth, there is still plenty of room for more, as the majority of children are not currently enrolled in governmentfunded preschools. Most states, for example, either limit their programs explicitly or give a preference to a targeted population-usually children living in poverty or at risk because of family circumstances. In 1995, Georgia became the first state to offer universal access to preschool for all

421. Although some commentators assiduously use either the term "preschool" or the term "prekindergarten program," implying that there is a significant difference between the two, we use the terms interchangeably to refer to any program that provides some instruction and thus differs from traditional day-care programs.

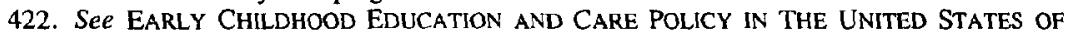
AMERICA 21 (OECD Country Note, July 2000).

423. Karen Schulman et al., Children's Def. Fund, SeEds of Success: State PREKINDERGARTEN INITIATIVES, 1998-1999, at 8 (1999).

424. See id.

425. Id.

426. The states include: Alabama, Alaska, Arizona, Arkansas, California, Colorado, Connecticut, Delaware, Florida, Georgia, Hawaii, Illinois, Iowa, Kansas, Kentucky, Louisiana, Maine, Maryland, Massachusetts, Michigan, Minnesota, Missouri, Nebraska, New Hampshire, New Jersey, New Mexico, New York, North Carolina, Ohio, Oklahoma, Oregon, Pennsylvania, Rhode Island, South Carolina, Tennessee, Texas, Vermont, Virginia, Washington, West Virginia, and Wisconsin, plus the District of Columbia. Id. at 13.

427. Id. at 4 .

428. Id. 
four-year-olds in the state, ${ }^{429}$ and in 1997, New York adopted a similar plan that is scheduled to go into effect in $2002{ }^{430}$ Universal access, however, remains the rare exception. Moreover, even targeted programs are not reaching all poor children: As of 1996, only thirty-six percent of children between the age of three and five whose families earned less than $\$ 15,000$ annually were in preschool programs. ${ }^{431}$

The structure and details of federal and state programs vary quite a bit from state to state and from community to community, making it difficult to describe a "typical" prekindergarten program. What most programs have in common, however, is that funding is provided to both public and private preschools. The federal Head Start program, for example, provides money to both public schools and private agencies, ${ }^{432}$ and indeed, most Head Start programs are operated by private agencies, including church-based preschool programs. ${ }^{433}$ Most state programs also provide money to both public and private schools. Of the forty-two states that sponsor programs, only seven limit funding to public schools, and six of the seven programs are relatively older ones, begun before $1985 .{ }^{434}$ The other thirty-five states fund both public and private programs. Hawaii actually has a preschool voucher program, which provides certificates to poor families that can be used to enroll their children in any licensed public or private preschool program. ${ }^{435}$

That funding is provided to public and private agencies does not necessarily mean that parents have a choice among programs. Some programs, like Head Start, do not offer much choice to parents: Those living in the community where the program operates are eligible to attend only the local program. ${ }^{436}$ Other programs offer a limited range of choices. In Georgia, for example, families can choose between public and private programs, but children residing in the attendance zone or district where the preschool program is located may be given first preference. ${ }^{437}$ Finally, some

429. RaChfl SCHUMaChER ET AL., STATE INITIATIVES To Promote EARLy Learning 55 (2001)

430. Linda Jacobson, Plans for "Universal" Preschool Gain Ground in New York State, EDUC. WK., Oct. 25, 2000, at 1 .

431. SCHULMAN ET AL., supra note 423 , at 5 .

432. 42 U.S.C. $\$ 9836$ (1994); 45 C.F.R. \& 1302.2 (2001).

433. See SChUlman ET AL., supra note 423 , at 7 .

434. The programs are in the District of Columbia, Kansas, Louisiana, Maine, New York, Wisconsin, and West Virginia. Anne Mitchell, Prekindergarten Programs in the States: Trends and Issues 2 (July 2001) (unpublished manuscript, on file with authors).

435. SCHULMAN ET AL., supra note 423 , at 44 .

436. This is suggested in the federal statute, see 42 U.S.C. $\$ 9840$ (1994 \& Supp. V 1999) (listing eligibility criteria), and it was confirmed by an expen, Anne Mitchell. E-mail from Anne Mitchell to James E. Ryan, Associate Professor, University of Virginia School of Law (Sept. 27, 2001) (on file with authors).

437. Office of School Readiness guidelines indicate that a provider may, but is not required to, give enrollment priority to students living in local school attendance zones or school districts. 
programs, such as Hawaii's, do not seem to place any geographic restrictions on choice. ${ }^{438}$ Even where choice is not restricted, however, transportation is not typically provided, and the lack of public or government-funded transportation can effectively restrict choice to local programs for some parents.

Our message to those seeking to expand school choice is simple: Support and try to shape efforts to expand access to government-funded preschools. Expanding access to government-funded preschools is an increasingly popular cause, supported by Democrats and Republicans alike. ${ }^{439}$ Part of the support stems from research that demonstrates both short- and long-term benefits from preschool, ${ }^{440}$ and part stems from the recognition that welfare reform, which pushes parents back into the workforce, requires some attention to child care. ${ }^{441}$ Whatever the precise motivation for support, however, it is clear that government funding and popular support for preschool education are growing. Between 1991 and 2000 , for example, state spending on preschool programs increased by over $\$ 1$ billion-from $\$ 700$ million $^{442}$ to nearly $\$ 2$ billion. ${ }^{443}$

In addition to supporting efforts to expand access to preschools, advocates of school choice should seek to ensure that choice remains a component of government-funded programs. The fact that most programs fund public and private preschools makes this a completely plausible goal. Indeed, perhaps the key point to recognize here is that government-funded preschools operate on a different basis than do most public elementary and secondary schools. The default rule for preschools is generally not the neighborhood public school. The status quo, therefore, is not as much of an obstacle in this context as it is in the context of school choice at the elementary and secondary level. Even teachers' unions, which strongly

See Ga. Office of Sch. Readiness, 2001-2002 Pre-K Program Guidelines $\& \quad 3.3$, http://www.osr.state.ga.us/FYlGuide2002.html (last visited Feb. 26, 2002).

438. SCHULMAN ET AL., supra note 423 , at 44 .

439. A 1989 bipartisan education summit initiated by the first President Bush, for example. recommended universal access to prekindergarten by the year 2000. Id. at 1 .

440. Some studies have indicated that children who participate in early childhood education programs are less likely to be held back or placed in special education programs later in their academic careers. EDWARD ZIGLER \& SUSAN MUENCHOW, HEAD START: THE INSIDE STORY OF AMERICA'S MOST SUCCESSFUL EDUCATIONAL EXPERIMENT 204 (1992). Other studies indicate that participation in early childhood education is associated with increased employment and postsecondary education. LAWRENCE J. SCHWEINHART ET AL., SIGNIFCANT BENEFTTS: THE HIGH/SCOPE PERRY PRESCHOOL STUDY THROUGH AGE 27 (1992); see also LYNN A. KAROLY ET AL., INVESTING IN OUR CHILDREN: WHAT WE KNOW AND DON'T KNOW ABOUT THE COSTS AND BENEFITS OF EARLY CHILDHOOD INTERVENTIONS (1998).

441. Early ChILdHoOd Education and Care POlicy in the United States of AMERICA 15 (OECD Country Note, July 2000) ("Most welfare recipients are single mothers who cannot work without child care."); see also Jacqueline L. Salmon, For Many Children, Nowhere To Go, WASH. POST, Sept. 19, 1999, at Al (describing a nationwide "childcare crunch").

442. SCHULMAN ET AL., supra note 423, at 4.

443. Mitchell, supra note 434 , at 5 . 
support the drive for increased access to preschool, are not insisting that funding go only to public programs. ${ }^{444}$ If state and federal governments continue to fund both public and private programs, as seems likely, one prominent reason to oppose choice-to keep money out of the hands of private schools-disappears.

The theory behind our suggested strategy is that experience may change perceptions. To the extent that parents experience school choice for their preschool-aged children, and to the extent that they appreciate having that choice, it seems reasonable to expect that some would continue to support choice programs that involve elementary and secondary schools. Working families in particular may find that being able to choose schools that are closer to their places of employment is preferable to the current system, which assigns most students to schools that are close to their homes. Suburban parents in general may discover that the ability to choose from a more diverse array of educational settings is valuable and worthy of support.

For this to work, access to government-funded preschools must expand to include parents who are currently not receiving assistance, including suburban, middle-class parents. This could happen by making preschool universally available at the government's expense, as it is in Georgia, or by instituting a sliding-scale benefits program, where the amount provided for tuition would depend on the parents' income level. ${ }^{445}$ It could also happen by simply allowing government-funded students to attend preschools with children whose parents pay full tuition, which does not typically happen under current programs. Whatever the method, the keys are to increase parental involvement in government-funded school choice programs at the preschool level, maintain participation by public and private preschool providers, and make efforts to inform those parents that school choice exists at this level.

One especially promising strategy would be to encourage the creation of more worksite preschools. Numerous news reports suggest that there is great demand among parents for on-site day-care centers and preschools, and that some employers are beginning to respond to that demand. ${ }^{446} \mathrm{~A}$ persistent problem, of course, is cost, which some employers and

444. Sandra Feldman, Remarks to the AFT QuEST Conference (Iuly 12, 2001), at http://www.aft.org/press/2001/quest01_speech.html. In her remarks, the president of the American Federation of Teachers endorsed universal early childhood education initiatives and pointed to the Head Start model as a prototype. Id.

445. The latter program was suggested by Feldman in her report. See id.

446. See, e.g., Gretchen Marquardt, Kids and Company: Abbott Offers Employees On-Site Child Care Facility, CHI. DAlly HERALD, Aug. 7, 2001, Neighbors, at 1; M.B. Taboada, Businesses See Benefits of On-Site Child-Care Centers, AUSTIN AM. STATESMAN, Sept. 24, 2001, at B1; Kindercare @Work To Provide Onsite Childcare for Employees at Satum, PR NEWSWIRE, June 20, 2000, LEXIS, Nexis Library, PR Newswire File. 
employees are unwilling or unable to bear. ${ }^{447}$ Government funding might help solve this problem and foster the creation of more worksite preschools. Such schools, it bears noting, would likely be fairly integrated by race and income, given that workplaces are generally more racially, ethnically, and socioeconomically diverse than are neighborhoods. ${ }^{448}$ If parents have a good experience with on-site preschools, moreover, it seems at least plausible that they might favor on-site elementary schools, which could be created as charter schools. ${ }^{49}$

There are, to be sure, a number of obstacles to increasing access to and choice among preschools. These include cost in general, transportation costs in particular, and ensuring that full-day programs are available for families with two parents who work full-time. None of these obstacles, however, seems insuperable, and programs across the country have addressed them. Indeed, the fact that Georgia has implemented a program that provides universal access to preschool suggests that doing so is politically feasible. That Hawaii has instituted what amounts to a preschool voucher program is further evidence of the possibilities that exist in this context. In short, although there will be hurdles to overcome, and although costs and other logistics may place constraints on programs, there is a great deal of room for creative thinking and innovative programs in this context, which could simultaneously assist young children and boost the cause for expanding school choice at the elementary and secondary school level.

Finally, in addition to the obstacles facing efforts to expand access to preschool, it is obviously possible that the experience of choice among preschools may not be enough to alter every or even most parents' perceptions of the costs and benefits of choice at the elementary and secondary level. ${ }^{450}$ At the same time, however, it seems plausible that some would change their perception, and it also appears from most studies that

447. See Tiffini Theisen, Day Care on the Job; It's a Perk That Remains Elusive for Most Parents Who Work, ORLANDO SENTINEL, July 18, 2001, at G1.

448. See Cynthia L. Estlund, Working Together: The Workplace, Civil Sociery, and the Law, 89 GEO. L.J. 1, 17-19 (2000) ("For most working adults, the workplace is where they are most likely to have genuine interaction across racial lines; in particular, it is the most frequent source of contact between black and white citizens."); see also Andrea Schoellkopf, On-Site Child Care Comforts School Employees, ALBUQUERQUE J., Jan. 11, 2001, at 4 (describing a preschool program at an elementary school that serves both poor students eligible for federal assistance and the children of teachers, which was created to satisfy teacher demand and to establish "a heterogeneous group" of preschoolers).

449. See Michael Utley, A Day-Caring Environment: Some Larger Companies, Concerned with Retaining Good Employees, Offer On-Site Day Care for Employees' Children, PREssENTERPRISE, Oct 1,2000, at H1 (describing one on-site center that serves kids up to six years old).

450. The existence of government-funded choice at the college and university level, for instance, which occurs through federal Pell grants and state grants, apparently has done little to increase support for such choice at the elementary and secondary level. Our intuition is that parents would see more of a connection between preschool choice and choice among elementary (and later) secondary schools, but there is obviously no guarantee of this. 
increasing access to preschool is a worthy goal in itself, separate and apart from its impact on subsequent school choice policies. ${ }^{451}$ The potential benefits, both direct and indirect, of increasing access to preschools thus seem worth the costs. Indeed, given the current intransigence that characterizes school choice politics, efforts to alter preferences and perceptions, even if they take a while to come to fruition, seem uniquely worthwhile. ${ }^{452}$

\section{CONCLUSION}

We end on a note of very cautious optimism. The political economy of school choice, which we have tried to explicate, suggests that the biggest obstacle to expanding choice in meaningful ways stems from suburban opposition to any changes to the status quo that might upset the suburbs' advantaged position. This opposition has been a constant in the area of school reform, and it has worked to shape reforms in ways that leave the financial and physical independence of suburban schools intact. Existing school choice programs conform to this historical pattern, as most leave suburban schools untouched: Those schools typically need not accept transfer students involuntarily, nor must their students participate in choice programs. If this pattern remains unaltered, we should not expect school choice to reach its theoretical potential in terms of racial or socioeconomic integration, academic achievement, or beneficial competition among public schools.

We hope that this Article constitutes, at the very least, a first step toward altering that pattern. Before obstacles can be overcome, they must be identified. Although it seems obvious to us that suburbanites constitute the largest obstacle to increasing opportunities for choice, their role in school choice has remained until now largely unexplored. This might seem mysterious at first, and readers may be wondering, as we did, why this point has remained somewhat obscure in choice debates. It becomes clear once the politics of choice are better understood. Neither side in the choice debate has much of an incentive to emphasize suburban opposition to school choice. Those in favor of school choice, especially private school choice, surely gain nothing by highlighting suburban opposition. It is much better for their cause if they can portray choice as universally popular and

451. See sources cited supra note 440 .

452. It is also possible that even if a substantial number of parents alter their stance toward choice, they will be outweighed by local residents without children, who might perceive any choice plan as a potential threat to their home values. At the very least, we would expect new coalitions to form among groups of suburbanites, with some parents, especially working parents, on one side of the choice debate, and property owners without children together with families with a stay-at-home parent (for whom a neighborhood school is the most convenient) on the other. 
single out culprits like teachers' unions as the reason why such a popular cause is often stymied. Conversely, those who oppose school choice often argue that limited programs, such as the ones that exist in Cleveland and Milwaukee, are the proverbial camel's nose under the tent. Allow limited choice programs, the argument goes, and the next thing you know, vouchers will be given mostly to white middle-class parents looking to flee public schools. It does not help this argument, of course, to point out that the odds of expanding choice are at the moment quite slim, given suburban support for local public schools and opposition to broad school choice plans.

Identifying suburban opposition may indeed be the first step toward overcoming it, but past experience and the emerging pattern among school choice programs should give pause to anyone attempting to do so. To be sure, there are ways to take small steps toward expanding school choice, as we have described. Existing programs may be strengthened and replicated elsewhere, and incentives can be used to ease the path toward expansion. Taken together, these steps could add up to significant expansions in some states and communities. Over the long term, however, change seems to await an alteration of suburban perceptions and preferences. And this, finally, is where preschools may help. To the extent that governmentfunded preschool programs can become an attractive alternative model for how education is provided, and to the extent that parents support this alternative, the cause of expanding school choice will be advanced. There is no guarantee, of course, that perceptions and preferences will change, but providing parents with the experience of school choice at the very beginning of their children's education seems more promising than any alternative we have seen or considered. 